\title{
The Law, Economics, and Politics of Federal Preemption Jurisprudence: A Quantitative Analysis
}

\author{
David B. Spence $\dagger$ \\ Paula Murray $\ddagger$
}

\section{TABLE OF CONTENTS}

Introduction.

I. The Origins of Modern Preemption Jurisprudence

A. History of Preemption Case Law.................................................1130

B. Modern Context of Preemption Conflicts ................................. 1135

II. Modern Preemption Jurisprudence.....................................................1138

A. Commerce Clause Jurisprudence.................................................1138

B. Supremacy Clause Jurisprudence ................................................1146

C. Evaluations of Modern Preemption Doctrine..............................1153

III. Analysis: Explaining Modern Preemption Decisions .......................1159

A. Some Threshold Issues .........................................................1159

1. Potential Bias Toward Preemption ........................................ 1159

2. Proposed Taxonomy of Explanatory Variables ....................1161

B. Explanatory Variables ...................................................................1164

1. Internal/Ideological Forces ...................................................... 1164

2. External/Circumstantial Forces.........................................1172

a. Case Type ........................................................................1172

b. Deference to Congress.......................................................1173

c. Public Alarm................................................................1176

d. Deference to Federal Agency ..........................................1177

Copyright $\odot 1999$ California Law Review, Inc.

$\dagger$ Assistant Professor, Legal Environment of Business, University of Texas. J.D., 1984; Ph.D., 1997.

$\ddagger \quad$ Professor, Legal Environnent of Business, University of Texas. J.D., 1980. The authors would like to: (1) thank Daniel Farber, Susan Rose-Ackerman, and James Hamilton for their comments on an earlier draft of this article; (2) acknowledge the helpful comments received on earlier drafts fronı seminar participants at Princeton University, the Umiversity of North Carolina, the University of Kansas, and the annual meetings of the Association for Public Policy Analysis and Management and the Academy of Legal Studies in Business; and (3) thank Liza Aguilar, Leah Castella, Amy Franklin, Lekha Gopalakrishnan, and Amy Livsey for their research assistance on this project. 
e. Relative Deference to State (vs. Local)

Regulation.....................................................................1178

C. Testing the Theories: A Multivariate Analysis ..........................1179

IV. Implications ...........................................................................1187

A. Implications for Preemption Doctrine .........................................1187

B. Implication for Judicial Decision Making ................................1193

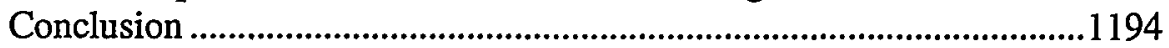

Appendix A: Table of Cases in the Sample...........................................1196

Our Sample: Lower Federal Courts .............................................1196

Supreme Court Cases .....................................................................1199

Appendix B: Notes on Statistics and Data Coding..................................1200

Explanation of Methods .............................................................1200

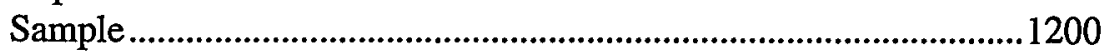

Sample Truncation and Selection on the Dependent

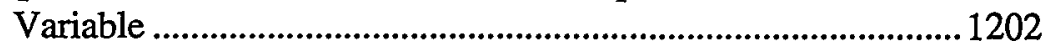

Coding the Dependent Variable ....................................................1203

Coding the Independent Variables ...............................................1203

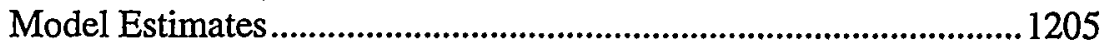




\title{
The Law, Economics, and Politics of Federal Preemption Jurisprudence: A Quantitative Analysis
}

\author{
David B. Spence \\ Paula Murray
}

Federal preemption case law under the Supremacy Clause and dormant Commerce Clause has been marked by a high degree of conflict and controversy. That is not surprising given the unusual ideological and political conflicts these cases pose. After describing federal preemption jurisprudence, the authors analyze a group of more than one hundred federal preemption decisions in the federal courts. All involve the exercise of state or local police power in the form of environmental, health, and safety regulation, covering a period from the late 1960s to the present. The authors employ both statistical analyses and more traditional analytic methods to discern some patterns in these decisions. The authors conclude that several different components of ideology, including judges' policy preferences and philosophies of regulation, explain these decisions, along with a variety of case-specific factors. The analysis supports a circumscribed "legal realist" view of judging. It also implies that politics play a central role in the resolution of preemption conflicts, despite the preemption doctrine's stated preference for market solutions to "externality" problems. Consciously or not, judges have effectively ensured that certain kinds of political distortions of the market for externalities survive, while others fail.

\section{INTRODUCTION}

With the rise of the inodern regulatory state has come an increase in the number of "preemption disputes," or cases that pit the regulatory authority of the federal government against the police power of states. Traditional constitutional jurisprudence has favored the federal government in these disputes. ${ }^{1}$ In recent years, however, politicians and scholars have signaled a "new federalisin," characterized by a growth in state and local

1. See, e.g., S. Candice Hoke, Transcending Conventional Supremacy: A Reconstruction of the Supremacy Clause, 24 CoNN. L. Rev. 829 (1992); Paul Wolfson, Preemption and Federalism: The Missing Link, 16 Hastings Const. L.Q. 69 (1988). 
power and a corresponding contraction of federal government power. ${ }^{2}$ Some recent Supreme Court decisions seem consistent with this trend, including United States $v$. Lopez, ${ }^{3} \mathrm{~m}$ which the Court adopted a more restrictive view of the scope of federal power under the Commerce Clause, and New York v. United States, ${ }^{4}$ in which the Court used the Tenth Amendment to restrict Congress's power to compel state government action. While decisions such as these may indeed reflect the Court's more restrictive view of federal power, ${ }^{5}$ other recent Supreme Court decisions have simultaneously strengthened the two major pillars of federal preemption: the dormant Commerce Clause ${ }^{6}$ and the Supremacy Clause. ${ }^{7}$ As a consequence, the lower federal courts take a broad view of federal preemption authority. Their decisions, however, have been both less consistent than the Supreme Court's and marked by an unusual amount of conflict. That conflict is apparent in the relatively large number of splits among the circuits and the inability of the Supreme Court to calm the preemption waters. ${ }^{8}$ The central objective of this Article is to examine and understand this body of case law, and thereby to edify the debate over current preemption doctrine.

We start with two basic observations. The first observation is that the question of whether a particular state or local environmental, health, and

2. Scholars across a number of disciplines have sounded this call. See, e.g., Barry G. Rabe, Power to the States: The Promise and Pitfalls of Decentralization, in ENvironmeNTAL PoLICY IN THE 1990s, at 31-52 (Norman J. Vig \& Michael E. Kraft eds., 3d ed. 1997); Stephen Gardbaum, New Deal Constitutionalism and the Unshackling of the States, 64 U. CHI. L. REv. 483 (1997); Charles Wise, Judicial Federalism: The Resurgence of the Supreme Court's Role in the Protection of State Sovereignty, 58 PUB. ADMIN. REv. 95 (1998). The Association for Public Policy Analysis and Management, an organization of bureaucrats and scholars, dedicated its 1996 annual research meeting to the subject of the increasing role of the states in bureaucratic governance. See APPAM Confcrcnce, The Shifting Locus of Public Policy: Will Policy Analysis Follow Suit? (Fall 1996). Among politicians, Ronald Reagan's "New Federalism" is perhaps the best of many examples of this theme. See RuCHARD A. Harris \& Sidney M. Milkis, The Politics of Regulatory Change: A Tale of Two Agencies 128-33 (1996).

3. 514 U.S. 549 (1995) (holding that Congress does not have the authority under the Commerce Clause to prohibit possession of firearms in the vicinity of schools).

4. 505 U.S. 144 (1992) (striking down the Low-Level Radioactive Waste Policy Act's "take title" provision, requiring states to accept ownership of waste or rcgulate according to statute's directives, as incousistent with the Tenth Amendmcnt).

5. See, e.g., Francis J. Facciolo \& Richard L. Stone, Avoiding the Inevitable: The Continuing Viability of State Law Claims in the Face of Primary Jurisdiction and Preemption Challenges Under the Securities and Exchange Act of 1934, 1995 Colum. Bus. L. Rev. 525; Donald P. Rothschild, $A$ Proposed "Tonic" with Florida Lime to Celebrate Our New Federalism, 38 U. MiamI L. Rev. 829 (1984); Paula A. Sinozich et al., Project: The Role of Preemption in Administrative Law, 45 ADMIN. L. Rev. 107 (1993).

6. The term "dormant Commerce Clause" is explained more fully infra note 30 and aecompanying text.

7. For a description of both constitutional provisions, sce infra Part I.A. See also Hoke, supra note 1; Benjamin T. Kurten, National Sohd Wastes Management Association v. Meyer: Another Strike Against a State's Ability to Save Its Landftll, 3 W1s. ENVTL. L.J. 245 (1996).

8. It is also evident in the unusual coalitions these disputes produce at the Suprcme Court, particularly in Commerce Clause jurisprudence. See infra Part III.A. 
safety regulation should be preempted poses an ideological quandary for individual federal judges. For most judges, whether liberal or conservative, these cases pit one dimension of their ideology, their principles of federalism, against another, their policy preferences or attitudes toward the particular local regulation at issue. Generally speaking, conservatives and Republicans tend to favor less federal regulation and greater state power; conversely, liberals and Democrats tend to favor more federal regulation and less state power. However, inost preemption cases involve a state or local regulation that is inore stringent than the corresponding federal regulation. For conservative judges, this means that upholding state power against a federal challenge will lead to inore regulation, not less; ideologically liberal judges face exactly the opposite quandary. Our second observation is that these cases impose strong political pressures on judges as well. In many cases, the decision to preempt will be an unpopular one that may reignite local fears over the particular issue the preempted local regulation was designed to address. Either or both of these two forcesideology and politics-may help explain the contentiousness and persistence of preemption conflicts in the federal courts.

In Part I of this Article, we trace the historical developinent of preemption jurisprudence froin the landmark case of Gibbons v. Ogden, ${ }^{9}$ and describe the context of most inodern preemption conflicts. In Part II, we outline modern preemption jurisprudence in the federal courts under both the Commerce Clause and the Supremacy Clause, noting that these cases involve a collision between federal authority and the state police power, and between powerful political forces and the jurisprudential tradition of federal supremacy.

In Part III, we present a quantitative analysis that sheds considerable light, we believe, on these decisions. We begin by examining the menu of possible forces and variables that may explain judges' preemption decisions. We divide these explanatory variables along two dimensions. One dimension distinguishes the explicit factors judges cite in their decisions from implicit factors that may also influence judges, but which they tend not to cite. The other dimension distinguishes judges' internal ideological forces from the external political and other circumstantial factors that can influence a decision. Focusing our attention on lower federal court decisions, ${ }^{10}$ we then attempt to draw out the effects of these variables as explanations for these decisions, using both simple bivariate and multivariate statistical analyses, as well as inore traditional, less quantitative analytical methods. ${ }^{11}$ While we do not claim to have identified a single touchstone that explains preemption jurisprudence, we do find some order amid the

\footnotetext{
9. 22 U.S. (9 Wheat.) 1 (1824).

10. We focus on lower federal court decisions for a variety of reasons, explained infra note 58 .

11. For a full discussion of our statistical analysis, see Appendix B, infra.
} 
chaos of these decisions. Both the bivariate and multivariate analyses paint a picture of judicial decision making that is both ideological and contextual. That is, ideological predispostions matter, but so does the legal and factual context. Not surprisingly, perhaps, judges appear to indulge the former within constraints imposed by the latter. Given the prevalence of Republicans on the federal bench, the influence of policy preferences and regulatory philosophy on these decisions helps to explain the modern preemption doctrine's hostility to state and local regulation.

In Part IV, we conclude with some thoughts on the implications of this analysis. We explore the practical impact of the role played by federal judges in ensuring that environmental costs are allocated by means other than state or local legislation. Specifically, we note (as have others) ${ }^{12}$ that part of the ideological basis for these decisions rests on faulty assumptions about the way the market allocates these costs, and that modern preemption doctrine seems to accept certain kinds of political distortions of this market while rejecting others, all im the name of market efficiency. We conclude that judges in preemption cases ought to evaluate cost-internalizing regulation more favorably than cost-shifting regulation, though our analysis implies that that is unlikely to happen. The next best alternative, we argue, is to promote cost-internalizing regulation through the least political route, one that minimizes the role of judges, who focus on policy, and avoids a contentious legislative process. To this end, we recommend that the Environmental Protection Agency ("EPA") move toward this goal, by improving its oversight of its existing programs and further developing its existing authority.

I

The Origins of Modern Preemption Jurisprudence

\section{A. History of Preemption Case Law}

Commerce Clause and Supremacy Clause jurisprudence each trace their ancestry to the 1824 landmark case of Gibbons v. Ogden, ${ }^{13}$ which represented the culmination of a long-simmering conflict over the proper distribution of power between the national government and the state governments. Under the Articles of Confederation, all sovereignty rested in

12. See infra Parts II.C and IV.

13. 22 U.S. (9 Wheat.) 1 (1824). The case is noteworthy for a number of other reasons as well, including the fame of many of the participants. The case involved an exclusive license originally granted by the state of New York to a group led by Robert Fulton, inventor of the steamboat, and later assigned to Ogden. The case was argued on behalf of Gibbons by Daniel Webster, and the opinion was written by then Chief Justice John Marshall. See Charles F. Hobson, The Great ChieF Justice: John Marshall and the Rule of Law 139-49 (1996); Merrill D. Peterson, The Great Triumvirate: Webster, Clay and Calhoun 103 (1987). 
the states and national policy coordination had proven difficult. ${ }^{14}$ Individual states had erected protective tariffs and other barriers to interstate commerce, and the inability of the federal government to raise revenue or compel recalcitrant states to adhere to national law had crippled the national government. ${ }^{15}$ These concerns motivated many of the delegates to attend the Philadelphia Convention, where two of their principal responses were the Commerce Clause and the Supremacy Clause. ${ }^{16}$

The Commerce Clause, one of the many clauses enumerating the powers of Congress at Article I, Section 8, simply authorizes Congress to "regulate Commerce with foreign Nations, and among the several States ...."17 During the Framing period, there was broad support among the founders for a national authority to regulate commerce. ${ }^{18}$ The Supremacy Clause, in Article VI, was more controversial. It states that the "Constitution, and the Laws of the United States which shall be inade in Pursuance thereof ... shall be the supreme Law of the Land..."19 Anti-Federalists feared that this clause represented "an unlimited grant of power to the general government" and that it would invite an abuse of that power. ${ }^{20}$ Federalists contended that the assignment of responsibility to the national government necessarily implied the authority to fulfill that responsibility, and that the Supreniacy Clause merely affirmed that fact. ${ }^{21}$ More

14. The Framers' frustration with this problem is reflected in Federalist No. 33, in which Alexander Hamilton argues that "the danger which most threatens our political welfare is that the State governments will finally sap the foundations of the Union...." THE FEDERALIST No. 33, at 203 (Alexander Hamilton) (Clinton Rossiter ed., 1961).

15. See Lance Banning, The Sacred Fre of Liberty: James Madison and the Founding of the Federal Republic 43-76 (1995); Stañley ElKins \& ERIc McKitrick, The Age of Federalism: The Early American Republic, 1788-1800, at 3-13, 77-114 (1993).

16. See BANnING, supra note 15, at 47-49, 141-42; see also Charles B. Schweitzer, Street Crime, Interstate Commerce, and the Federal Docket: The Impact of United States v. Lopez, 34 DuQ. L. REV. $71,82-85$ (1995).

17. U.S. Const. art. I, $\$ 8, \mathrm{cl} .3$.

18. James Madison, for example, had resisted federal regulation of commerce as a member of Congress under the Articles of Confederation, yet came to be one of the strongest advocates for such a power in the debate over ratification of the Constitution. See BANNING, supra note 15, at 47; see also A. McLaughlin, A Constitutional History of the United States 137-47 (1935); Jack N. Rakove, Original Meanings: Politics and Ideas in the Making of the Constitution 46-47 (1996). In Federalist No. 42, Madison makes this argument as if he is stating the obvious:

The defect of power in the existing Confederacy to regulate the commerce between its several members is in the number of those which have been clearly pointed out by experience.... The necessity of a superintending authority over the reciprocal trade of confederated States has been illustrated by other examples as well as our own.

The Federalist No. 42, at 267-68 (James Madison) (Clinton Rossiter ed., 1961).

19. U.S. CONST, art. VI, cl. 2.

20. Herbert J. Storing, What the ANti-Federalists Were For: The Political Thought OF THE OPPONENTS OF THE CONSTITUTION 28 (1981).

21. See, e.g. , The Federalist No. 33, supra note 14, at 202 (stating that the Supremacy Clause is "only declatory of a truth which would have resulted by necessary and unavoidable implication from the very act of constituting a federal government and vesting it with certain specified powers"); see also The Federalist No. 44, at 286 (James Madison) (Clinton Rossiter ed., 1961) (arguing that 
importantly, the Federalists noted that the powers of the national government were limited, in the first imstance, to those enumerated within the Constitution; by implication, then, the Constitution reserved all remaining powers to the states and the people. Thus, federal supremacy was less dangerous than Anti-Federalists claimed because national law was "supreme" only within a very limited sphere. ${ }^{22}$

While the Federalist arguments carried the day in the battle over ratification, they did not end the debate over the meaning and reach of these two constitutional provisions. As the constitutional design was put into practice, fundamental and repeated conflicts ${ }^{23}$ over the reach of national government authority ultimately led to the formation of the nation's first political parties, ${ }^{24}$ under whose banners the conflict continued. Subsequently, the locus of conflict shifted to the courts, as litigation over federalism issues raised the larger question of where ultimate sovereignty in the new republic rested. ${ }^{25}$ It was against this backdrop that the Supreme Court first addressed the scope of these two constitutional provisions in Gibbons

without the Supremacy Clause, the Constitution would be "evidently and radically defective"). On this point, Stephen Gardbaum argues essentially that the Anti-Federalist fears have been bornc out. Professor Gardbaum contends that the notion of federal supremacy does not necessarily imply the power to preempt, but that decisions from the early tweutieth ccntury created such a right. See Stephen A. Gardbaum, The Nature of Preemption, 79 CoRNELl L. Rev. 767 (1994).

22. See, e.g., The Federalist No. 27, at 177 (Alexander Hamilton) (Clinton Rossitcr ed., 1961) (noting that national laws "as to the enumerated and legitimate objects of its jurisdiction will become the SUPREME LAW of the land," and that the states will be subject to national authority "as far as its just and constitutional authority extends ...."). Ultimately, of course, the Tenth Amendment to the Constitution codified this argument. See U.S. CoNST. amend. X ("The powers not delcgated to the Umited States by the Constitution, nor prohibited by it to the States, are reservcd to the Statcs respectively, or to the people.").

23. These conflicts are recounted in many histories of the time. See, e.g., BANNING, supra note 15, at 293-365 (focusing on low Madison grappled with these issues); ELKINS \& MCKITRICK, supra note 15, at 77-162, 195-209 (focusing on how Jefferson grappled with these issues); see also WILLARD Sterne Randall, Thomas JefFerson: A Life 505-55 (1993) (focusing on Jefferson).

24. The "Federalist" party embodied the Hamiltonian perspective, while Jeffersonians called themselves "Republicans." Many political scientists and historians have chronicled their risc. See, e.g., John H. Aldrich, Why Parties?: The Origin and Transformation of Political Parties in AMERICA 68-96 (1995); BANNING, supra note 15, at 293-365; ELKINS \& MCKITRICK, supra note 15, at 257-302; Ronald P. Formisano, Federalists and Republicans: Parties, Yes-System, No, in PaUL KIEPPNER et al., The Evolution of AMERICAN Electoral SYSTEMs 33 (1981).

25. After Marbury v. Madison, 5 U.S. (1 Cranch) 137 (1803), the Supreme Court continued to assert its claim to be the final arbiter of these conflicts, and Gibbons $v$. Ogden is but one example of that practice. It is also well known that, despite this practice, Jeffcrsonians accepted neither the expansive view of federal power the Court articulated nor the Court's assertion of ultimate jurisdiction over this issue. Jefferson and Madison continued to oppose the Hamiltonian vision throughout their lives. They advocated Jefferson's "nullification doctrine," embodied in the Virginia and Kentucky resolutions, and asserted states' rights to make independent determinations of the constitutionality of national laws. See BANNING, supra note 15, at 387-94; ElKINS \& MCKITRICK, supra note 15, at 71025. Indeed, the validity of the nullification doctrine continued to be debated by politicians until the Civil War. See Hobson, supra note 13, at 11-12, 211-12; Charles G. Sellers, The Market REVOLUTION: JACKSONIAN AMERICA, 1815-1846, at 318-21, 326-31 (1991). 
v. Ogden. By the time the case was heard, both the Court and Chief Justice Marshall had established their Federalist credentials. ${ }^{26}$

In Gibbons, the state of New York had granted Ogden an exclusive license to operate steamboats on the state's waterways. Ogden brought suit challenging the operation of steamboat service between New Jersey and New York City by a competitor, Gibbons, who had no state license to operate a steamboat service. To Federalists, the monopoly granted by the state of New York looked very much like the kind of impediment to trade that had proven so troublesome under the Articles of Confederation. Consequently, the Court's decision could not have been a surprising one at the time. In announcing the Court's opinion, Justice Marshall first offered a Hamiltonian or Federalist conception of national sovereignty, ${ }^{27}$ and then deduced from that conception a broad (but not exclusive) federal power to regulate commerce. ${ }^{28}$ Because this power was not exclusive, Marshall next dealt with the question of what happens when states, acting within the proper sphere of their authority, enact laws that "collide" with federal laws or the Constitution. That question, said Marshall, is answered by the Supremacy Clause, which specifies that in these situations the otherwise proper state law must give way. Consequently, Gibbons' federal authority to operate his steamboat trumped Ogden's New York license to operate, because the statute authorizing the former preempted the statute authorizing the latter. ${ }^{29}$

Since Gibbons v. Ogden, the Supreme Court has continued to uphold this broad view of national power under both the Commerce Clause and the Supremacy Clause. The Court's subsequent decisions have developed further the notion of the dormant Commerce Clause, which refers to the idea that the Constitution's grant of regulatory power over interstate cominerce to Congress acts, by negative implication, as a restraint on state

26. See Elkans \& MCKrTtrick, supra note 15, at 128-30; HoBson, supra note 13, at 111-39.

27. Marshall almost immediately reached the heart of the issue that was to dominate public policy and constitutional law until the Civil War:

It has been said, that [the states] were sovereign, were completely independent, and were connected with each other only by a league. This is true. But, when these allied sovereigns converted their league into a government, when they converted their Congress of Ambassadors ... into a Legislature,... the whole character in which the States appear, underwent a change, the extent of which must be determined by a fair consideration of the instrument by which that change was effected.

This instrument contains an enumeration of powers expressly granted by the people to their government.

Gibbons, 22 U.S. at 187.

28. See id. at 187-209.

29. See id. at 219-221. Interestingly, this decision was prophesied by some Anti-Federalists. One of the Federalist defenses of federal supremacy had been the argnment that the federal courts would serve as a check against the expansion of federal power. Anti-Federalists argued, to the contrary, that federal courts would be sympathetic to expansions of federal authority. See Gardbaum, supra note 21, at 787; Jack N. Rakove, The Origins of Judicial Review: A Plea for New Contexts, 49 STAN. L. REv. 1031,1050 (1997). 
regulatory power irrespective of whether that authority has been exercised. $^{30}$ The Court today applies a two-step test to regulations that may burden interstate commerce. If the regulation at issue is protectionist, facially discriminatory, or has a discriminatory effect or purpose, a virtually per se rule of invalidity applies. ${ }^{31}$ Where the regulation does not meet these criteria and serves other legitimate ends, the Court will engage in a balancing analysis, upholding the regulation unless "the burden imposed on [interstate] commerce is clearly excessive in relation to the putative local benefits." "32

The Court's Supremacy Clause jurisprudence has also evolved since Gibbons v. Ogden, articulating several ways in which federal law may be found to preempt state or local law. Congress can preempt state or local law expressly by way of explicit statutory language. Preemption also may be inferred (so-called "implied preemption") where (1) congressional regulation occupies the field, leaving no room for supplemental state regulation, or (2) state or local law actually conflicts with federal law. ${ }^{33}$ Thus, the black. letter law of preemption is well established. In the one hundred fifty years following Gibbons v. Ogden, the courts invoked the dormant Commerce Clause to invalidate a wide variety of state and local laws, many of which were designed to protect local industry against out-of-state competition. ${ }^{34}$ Likewise, the courts invoked the Supremacy Clause to overturn a variety of state and local laws deemed to be preenpted by federal statutes. ${ }^{35}$ The last three decades, however, have seen drastic changes in the legal and political context in which the law of preemption applied. These changes, in turn, have refueled the controversy over preemption conflicts.

30. See, e.g., H.P. Hood \& Sons v. DuMond, 336 U.S. 525 (1949). See generally Catherine Gage O'Grady, Targeting State Protectionism Instead of Interstate Discrimination Under the Dormant Commerce Clause, 34 SAN DiEgo L. REv. 571 (1997); Martin H. Redish \& Shane V. Nugent, The Dormant Commerce Clause and the Constitutional Balance of Federalism, 1987 DUKE L.J. 569 (1987).

31. See H.P. Hood \& Sons, 336 U.S. at 545 (allowing regulation if the state or local government can show that there are no less discriminatory means to reach the legitimate local objectives).

32. Pike v. Bruce Church, Inc., 397 U.S. 137, 142 (1970) (overturning a fruit packaging law); see also Raymond Motor Transp., Inc. v. Rice, 434 U.S. 429, 440-42 (1978) (overturning state trucking regulations).

33. These principles are outlined generally in Capital Cities Cable, Inc. v. Crisp, 467 U.S. 691, 699 (1984) and English v. General Electric Co. 496 U.S. 72, 78-79 (1990), For a good summary of the post-Gibbons case law, as well as an argument that the Supremacy Clause was intended to create only conflict preemption, see Gardbaum, supra note 21, at 787-807. The gist of Gardbaum's argument rests on his distinction between the notion of "supremaey," which implies that one law trumps another when they conflict, and "preemption," which implies the removal of the power to act at all. The Supremacy Clause, says Gardbaum, was intended merely as a dispute resolution mechanism, but has evolved into a grant to Congress of latent exclusivity. See id. at 774-77.

34. For a summary, see O'Grady, supra note 30.

35. For a summary, see David M. O'Brien, The Supreme Court and intergovernmental Relations: What Happened to "Our Federalism"?, 9 J.L. \& PoL. 609 (1993). 


\section{B. Modern Context of Preemption Conflicts}

The primary reason for the recent growth in the number and importance of preemption cases is the explosive growth in the number of federal environmental, health, and safety laws and regulations during the last three decades..$^{36}$ The modern environmental and consumer movement $\mathrm{s}^{37}$ spawned the "environmental decade" 38 of the 1970s, during which Congress passed the four statutory horsemen of pollution control-the Clean Air Act of $1970,{ }^{39}$ the Federal Water Pollution Control Act of $1972,{ }^{40}$ the Resource Conservation and Recovery Act of $1976,{ }^{41}$ and Superfund ${ }^{42}$-as well as the Occupational Safety and Health Act, ${ }^{43}$ the Toxic Substances Control Act, ${ }^{44}$ and the Federal Insecticide, Fungicide and Rodenticide Act, ${ }^{45}$ among others. Subsequent legislative activity in the 1980 s and ' 90 s aimed at strengtheming and fine-tuning the system established in the $1970 \mathrm{~s} .{ }^{46}$ With these developments federal environmental law effectively eclipsed state regulation, which had been deemed inadequate to the task of environmental protection.

The new federal requirements were not only more stringent than the existing state regulations, but also often replaced existing federal programs that had delegated primary regulatory responsibility to the states. ${ }^{47}$ These

36. According to one study, more than half of the federal statutes which preempt state and local regulation have been passed since 1970, and about one-third of those fall into the category of "health, safety and natural resources" regulation. See O'Brien, supra note 35, at 619 . This is the largest of $O$ 'Brien's groupings. The others are civil rights, commerce, tax and finance, and preemption rehef.

37. See generally JoEl HANDLER, SOCIAL MOVEMENTS AND THE LEGAL SySTEM (1982); Henry P. Caufield, The Conservation and Environmental Movements: An Historical Analysis, in Environmental Politics and Policy 13, 13-56 (James P. Lester ed., 1989); Ann N. Constain and James P. Lester, The Evolution of Environmentalism, An Historical Analysis, in ENVIRONMENTAL Politics AND POLICY (James P. Lester ed., 1995).

38. This term is often attributed to political scientist Lettie McSpadden Wenner. See LETTIE M. Wenner, The Environmental Decade in Court (1982).

39. Clean Air Amendments of 1970, Pub. L. No. 91-604, 84 Stat. 1676 (codified as amended at 42 U.S.C. $\$ \S 7401-7671 \mathrm{q}(1994))$.

40. Federal Water Pollution Control Act Amendments of 1972, Pub. L. No. 92-500, 86 Stat. 816 (codified as amended at 33 U.S.C. §§ 1251-1387 (1994)).

41. Pub. L. No. 94-580, 90 Stat. 2795 (codified as amended at 42 U.S.C. $\$ \S 6901-6992 \mathrm{k}$ (1994)).

42. Comprehensive Environmental Response, Compensation and Liability Act of 1980, Pub. L. No. 96-510, 94 Stat. 2767 (codified as amended at 42 U.S.C. $\$ \$ 9601-9675$ (1994)). Superfund was enacted in 1980 but is generally considered to be part of the "environmental deeade" in Congress.

43. Occupational Safety and Health Act of 1970, Pub. L. No. 91-596, 84 Stat. 1590 (codified as amended at 29 U.S.C. $\$ \S 651-678(1994))$.

44. Pub. L. No. 94-469, 90 Stat. 2003 (codified as amended at 15 U.S.C. $\$ \S 2601-2692$ (1994)).

45. Federal Insecticide, Fungicide, and Rodenticide Act, Pub. L. No. 80-104, 61 Stat. 163 (codified as amended at 7 U.S.C. $\$ \$ 136-136 y$ (1994)).

46. For a summary of the "stages" of the modern federal environmental movement, see ROBERT V. Percival et al., Environmental Regulation: Law, Science and Policy 102-114 (2d ed. 1996).

47. Pre-1970 federal air and water pollution regulation statutes, for example, began with legislatively-mandated processes for studying pollution problem, followed by legislation placing the responsibility for estabhshing regulatory standards on the states. See, e.g., Clean Air Act of 1963, Pub. 
new programs "federalized" environmental, health, and safety law in two basic ways. First, all established nationally applicable federal standards, replacing existing state standards. ${ }^{48}$ Second, under each of these new programs, the EPA undertook the administration and enforcement activities directly ${ }^{49}$ or oversaw a systen of delegated state administration and enforcement. ${ }^{50}$ The reasons for this "federalization" of environmental law included concerns about the efficacy of existiug state-based programs, the related concern that states lacked the capacity to regulate effectively, and iudustry's preference for umform standards over a multiplicity of state standards. ${ }^{51}$

But the niost commonly cited explanation for establishing a system of broad federal regulatory power over environmental issues is the concern

L. No. 88-206, 77 Stat. 392 (codified as amended at 42 U.S.C. $\$ \$ 7401-7642$ (1994)) (calling for studies of air pollution by the Secretary of the Department of Health, Education and Welfare), and Air Quality Act of 1967, Pub. L. No. 90-148, 81 Stat. 485 (codified as amended at 42 U.S.C. $\$ \$ 7401$ $7671 \mathrm{~g}$ (1994)) (establishing a procedure for adoption of ambient air quality standards by the states). The statutory precedents to the Clean Water Act are more fragmented. For a summary, see Frank J. Barry, The Evolution of the Enforcement Provisions of the Federal Water Pollution Control Act: A Study of the Difficulty in Developing Effective Legislation, 68 MicH. L. REv. 1103 (1970).

48. Thus, for example, minimum ambient air quality standards and water pollution standards are established by the Environmental Protection Agency ("EPA") under the authority of the Clean Air Act and the Clean Water Act, respectively. See 40 C.F.R. $\S \S 61,125$ (1998).

49. Thus, for example, the process of approving new toxic chemicals and new pesticides rests exclusively in the hands of the EPA. See 40 C.F.R. $\$ \$ 22,152$ (1998).

50. For example, states are authorized to administer and enforce certain permitting requirements of the Clean Air Act, the Clean Water Act, and the Resource Conservation and Recovcry Act ("RCRA"), but only if they meet established requirements set by the EPA. See 40 C.F.R. $\$ 67$ (Clean Air Act); and 40 C.F.R. $\$ 123$ (Clean Water Act); and 40 C.F.R. pt. 271 (RCRA). Furthermore, the EPA has extensive oversight powers once this authority is delegated. The EPA can try to revoke a state's delegated authority to regulate if it is unhappy with the way the state program is being administered. Indeed, at the instigation of environmental groups, the EPA recently has threatened such sanctions against states that have passed so-called environmental audit privilege laws. See Narrower Audit Law Would Clear Way for Final Delegation Approval, EPA Says, 28 Env't Rep. (BNA) 484 (July 11, 1997) (reporting that the EPA conditioned Michigan's approval to administer Title V of the Clean Air Act on state's willingness to change state audit privilege law); Kyle Niederpruem, EPA Targets State Environmental Law Agency-Wants Change in Law that Allows Firm to Find, Fix Pollution Problems Without Penalty, InDiAnAPolis STAR, July 21, 1998, at B1 (chronicling EPA pressure on the state of Indiana to change its audit privilege law). Those thrcats, in turn, prompted calls for congressional hearings on the subject in the spring of 1998. See EPA Hearings Sought on State Laws, 28 Env't Rep. (BNA) 2435 (Mar. 20, 1998). On another occasion, the agency commenced proceedings to revoke the state of North Carolina's authority to administer its hazardous waste management program under RCRA, based on its dissatisfaction with the state's facility siting laws. See North Carolina Law No Reason to Revoke RCRA EPA Authority, Administrative Law Judge Rules, 20 Env't Rep. (BNA) 1979 (Apr. 20, 1990). For additional examples of tight federal control over the delegation of regulatory authority to states, see the discussion of the Toxic Substanccs Control Act and Occupational Safety and Health Acts, infra Part II.B.

51. For a summary of these bases for federal regulation, see E. Donald Elliot et al., Toward a Theory of Statutory Evolution: The Federalization of Environmental Law, 1 J. LAW, ECON. \& ORG. 313 (1985). 
over what Richard Stewart has called the "race to the bottom."52 The race to the bottom posits a situation in which local governments coinpeting for manufacturing jobs are caught in a kind of a prisoner's dilemma, ${ }^{53}$ coinpeting to attract industry by lowering their environmental standards. ${ }^{54}$ While Stewart's analysis offered a powerful justification for national environmental standards, the so-called "not in iny backyard," or "NIMBY," movements represent an equally powerful and opposing form of local competition, whereby local governments seek to shift environmental costs to others. ${ }^{55}$ Indeed, the very same political pressures that led to the passage of federal environmental, health, and safety laws spawned corresponding state and local laws as well. ${ }^{56}$ Many of these state and local laws represent

52. Richard B. Stewart, Pyramids of Sacrifice? Problems of Federalism in Mandating State Implementation of National Environmental Policy, 86 YALE L.J. 1196, 1212 (1977) (arguing that the mobility of industry poses a risk for any individual state or community that decides unilaterally to adopt high environmental standards; communities may reasonably "fear that the resulting environmental gains will be more than offset by movement of capital to other areas with lower standards").

53. The prisoner's dilemma is an allegorical illustration of a common collective action problem in environmental policy. For a discussion of the dilemma in the context of environmental law, see David B. Spence, Paradox Lost: Logic, Morality, and the Foundations of Environmental Law in the 21st Century, 20 Colum. J. EnvTL. L. 145 (1995).

54. See Stewart, supra note 52, at 1211. Richard Revesz has answered Stewart by contending that when local governments make the decision to lower their environmental standards, that decision reflects a balancing of costs and benefits by those local governments, and an implicit decision that the benefits (jobs) are at least equal to the costs (environmental externalities). See Richard L. Revesz, Rehabilitating Interstate Competition: Rethinking the "Race-to-the-Bottom" Rationale for Federal Environmental Regulation, 67 N.Y.U. L. REV. 1210 (1992); see also DAVID SCHOENBROD, TIME FOR The Federal Environmental Aristocracy to Give UP (1998) (also echoing Revesz); Henty N. Butler \& Jonathan R. Macey, Externalities and the Matching Principle: The Case for Reallocating Environmental Regulatory Authority, 14 YALE L. \& PoL'Y REv. 23, 31 (1996) (echoing Revesz's arguinent); Wallace E. Oates, Thinking About Environmental Federalism, 130 Resources 14 (Winter 1998) ("The central idea emerging from the literature in public economics is that the responsibility for providing a particular public service should be assigned to the smallest jurisdiction whose geographical scope encompasses the relevant benefits and costs associated with the provision of the service."). For a good, recent discussion of this debate, see Kirsten H. Engel, State Environmental Standard-Setting: Is There a "Race" and Is It "To the Bottom"?, 48 HASTINGS L.J. 271, 275 (1997) (defending the race-tothe-bottom rationale for federal regnlation). Revesz's argument is generally inapplicable, however, to those NIMBY movements that seck to exclude hazards from communities while retaining the benefits of the activity that produced the hazard at issue, since this cost-shifting distorts the balancing of costs and benefits. See Daniel Ingberman, Siting Noxious Facilities: Are Markets Efficient?, 29 J. ENVTL. ECON. \& MGMT. S-20 (1995), whose analysis also demonstrates that this problem exists even when all costs and benefits remain within the jurisdiction, because if impacts are concentrated on those closest to the noxious facility, a majority of voters within that boundary will suffer less than average impacts. See also infra notes 163-69 and accompanying text.

55. See generally Vicki Been, What's Fairness Got to Do With It? Environmental Justice and the Siting of Locally Undesirable Land Uses, 78 CORNELL L. REV. 1001 (1993); Richard J. Lazarus, Pursuing "Environmental Justice": The Distributional Effects of Environmental Protection, 87 Nw. UNIV. L. REV. 787 (1993).

56. For a good discussion of the development of state environmental regulatory programs and regulatory capacity, see Charles E. Davis \& James P. Lester, Federalism and Environmental Policy, in ENVIRonmental Politics AND Policy, supra note 37, at 57-84. Two good analyses of current environmental regulation in the states are Rabe, supra note 2, at 31-52, and NATIONAL ACADEMY of 
efforts by citizens to keep pollution or industrial byproducts out of their communities. It is this local cost-shifting phenomenon that triggers most modern preemption litigation, usually when federal law permits an activity that imposes environmental costs on unwilling locals. ${ }^{57}$ Applying the general prohibitions of the Commerce Clause and Supremacy Clause to these politically charged regulatory conflicts is no small feat. Not surprisingly, the federal courts have struggled mightily to define the boundary between federal authority, on the one hand, and state and local authority, on the other. We turn to that struggle next.

II

\section{MODERN PREEMPTION JURISPRUDENCE}

In this Part we outline the modern preemption case law, turning first to Commerce Clause jurisprndence and then to the Supremacy Clause cases. Our focus here is on the recent evolution of the case law, particularly in the lower courts. ${ }^{58}$

\section{A. Commerce Clause Jurisprudence}

One byproduct of the modern NIMBY phenomenon has been regional shortages of waste disposal capacity, ${ }^{59}$ as siting new disposal facilities has

Public Administration, Setting Priorities, Getting Results: A New Direction for the ENVIRONMENTAL Protection AgenCy (1994), especially chapter 4.

57. The literature on NIMBY movements is enormous. See generally Daniel Mazmanian \& David Morrell, The "NIMBY" Syndrome: Facility Siting and the Failure of Democratic Discourse, in ENviRONMENTAL PoLICY IN THE 1990s, supra note 2, at 125 (examining both the causes of NIMBY movements and alternative siting procedures); Been, supra note 55; Carol E. Dinkins, Impact of the Environmental Justice Movement on American Industry and Local Government, 47 ADMIN. L. REV. 337 (1995) (discussing generally the environmental justice movement's impact on policy, including siting); Bruno S. Frey \& Felix Oberholzer-Gee, Fair Siting Procedures: An Empirical Analysis of Their Importance and Characteristics, 15 J. PoL'Y ANAL Ysis \& MGMT. 353 (1996) (analyzing the impact of siting procedures quantitatively); Lazarus, supra note 55; Douglas J. Lober, Why Protest?: Public Behavioral and Attitudinal Response to Siting a Waste Disposal Facility, 23 Por'y STUD. J. 499 (1995) (analyzing public opinion toward siting decisions among affected individuals). For a stark illustration of the effects of this desire to shift costs on landfill siting decisions, sce 1ngberman, supra note 54, at S-24 (showing how Pennsylvania counties tended to site their landfills on county borders).

58. This focus on lower court decisions is a prelude to our analysis in Part III. We examine Supreme Court decisions here as well, but primarily as a backdrop to our analysis of lower court decisions. The discussion in this section covers most, but not all, modern cases involving federal preemption of local police power regulation, for several reasons which we explain in greater detail in Appendix B, infra. First, we have limited our discussion here (and our analytical sample of cases in Part III) to cases involving genuine disputes over unresolved legal issues, that is, cases in which the judges' decision is not clearly dictated by higher court precedent. We have also limited our sample in ways which maximize comparability of cases. Therefore, within the universe of preemption cases involving local police power regulation, we have restricted ourselves to those addressing an issue of environmental, health or safety concern. Likewise, we have limited our Supremacy Clause cases to those arising under federal statutes for which there is a genuine preemption issue.

59. See Erik T. Koons, Casenote, Without a Clue and Still Without a Master Plan: Municipalities Left Uncertain How to Manage Waste Disposal Crisis in Wake of Third Circuit 
grown increasingly difficult. These shortages, in turn, have prompted attempts by state and local governments to control both the use of disposal capacity and the flow of waste within their borders. The result has been a growing number of cases addressing the question of whether such regulations run afoul of the Commerce Clause. ${ }^{60}$ The first of these cases was City of Philadelphia $v$. New Jersey, ${ }^{61}$ in which the Supreme Court overturned a $1975 \mathrm{New}$ Jersey statute banning the importation of waste from out-of-state. ${ }^{62}$ After first putting to rest any doubt that waste disposal was "commerce" within the meaning of the Commerce Clause, ${ }^{63}$ the Court apphed the two-step Commerce Clause analysis, ${ }^{64}$ concluding that the statute was facially discriminatory and unconstitutional per se as simple economic protectionism. $^{65}$

Following Philadelphia v. New Jersey, states and local governments became more creative in drafting waste regulations. Typical was the approach taken by the state of Alabama, which enacted a statute that "conditionally authorized" waste imports by requiring state approval of individual waste shipinents into the state..$^{66}$ In National Solid Wastes Management Ass'n v. Alabama Department of Environmental

Decision in Harvey \& Harvey, Inc. v. County of Chester, 9 VilL. ENvTL. L.J. 225 (1998) (stating that $80 \%$ of landfills that operated in 1989 will exhaust their capacities and close within the next fifteen years). Several studies attribute capacity shortages to NIMBY movements. See, e.g., Been, supra note 55, at 1002 (ascribing shortages to NIMBY movements); Susan Hunter \& Kevin M. Leyden, Beyond NIMBY: Explaining Opposition to Hazardous Waste Facilities, 23 POL'Y STUD. J. 601 (1995) (arguing that "the main reason [hazardous waste] facilities are not being built is that the public opposes them. ..."); William H. Lewis, Jr., Hazardous Waste Facility Siting: Ultimate Authority Vested in Local Opinion, 2 NAT. REs. \& ENv'T 24 (1986) (also ascribing shortages to NIMBY movements).

60. One Second Circuit judge summarized this phenomenon as follows:

A law professor at Harvard is said to have remarked facetiously, a generation ago, that the greatest constitutional cases had concerned the sale and distribution of milk.... Although the flood of milk cases has receded in recent years, it has given way to a federal docket that is just as clogged with-of all things-garbage.

SSC Corp. v. Town of Smithtown, 66 F.3d 502, 505 (2d Cir. 1995) (Carbranes, J.).

61. 437 U.S. 617 (1978).

62. See N.J. Stat. ANN. § 13-1 I-10 (West. Supp. 1978), repealed by 1981 N.J. Laws 78, 1. The City brought suit in New Jersey state court, and the trial court granted summary judgment for the plaintiff on the grounds that the statute discriminated against interstate commerce. Ultimately the New Jersey Supreme Court reversed, finding the statute advanced legitimate health and environmental objectives and had hittle burden on interstate commerce. See Hackensack Meadowlands Dev. Comm'n v. Municipal Sanitary Landfill Auth., 348 A.2d 505 (N.J. 1975).

63. See City of Philadelphia, 437 U.S. at 621-22 ("All objects of interstate trade merit Commerce Clause protection.").

64. Sce discussion of the H.P. Hood and Pike line of cases, supra notes 30-32 and accompanying text.

65. See City of Philadelphia, 437 U.S. at 628.

66. The Alabama legislature in 1989 was concerned about the nation's largest commercial hazardous waste facility, located in Emelle, Alabama, which accepted hazardous waste from forty-eight states. The 1989 statute was the so-called "Holley Bill," which prevented commercial waste facilities from accepting hazardous waste generated in other states unless the state pre-approved the shipment and the wastes were treated prior to disposal. See AlA. CoDE \$22-30-11 (Supp. 1989). 
Management, ${ }^{67}$ the Eleventh Circuit held that the Alabama statute violated the Commerce Clause. The court found a per se violation, recognizing that while the hazardous waste Alabama sought to regulate was more dangerous than the waste involved in Philadelphia v. New Jersey, the out-of-state waste was not inherently more dangerous than in-state waste. ${ }^{68}$ Undeterred by the decision, the Alabama legislature in 1990 enacted a statute that established a fee system for hazardous waste disposal under which an "additional fee" was charged for waste generated outside of Alabama. ${ }^{69}$ The Alabama courts sustamed the law, ${ }^{70}$ but in Chemical Waste Management, Inc. v. Hunt, ${ }^{71}$ the Supreme Court found that the additional fee provision facially discriminated agamst out-of-state waste. ${ }^{72}$

The state of Michigan responded differently to Philadelphia v. New Jersey. Rather than regulating or restricting imports, Michigan imposed comprehensive waste-management planning obligations on Michigan counties and required that no county accept solid waste from outside the county for disposal unless authorized to do so in the county's waste plan. ${ }^{73}$ When landfill owners challenged the statute, neither the district court nor

67. 910 F.2d 713 (11th Cir. 1990).

68. See id. at 720. The district court had granted summary judgment for the state finding no Commerce Clause violation. SeeNational Solid Wastes Management Ass'n v. Alabama Dep't of Envtl. Management, 729 F. Supp. 792 (N.D. Ala. 1990); see also Chambers Medical Techs. of S.C., Inc. v. Bryant, 52 F.3d 1252 (4th Cir. 1995) (finding that South Carolina's fluctuating cap on infectious medical waste did not facially or in practice discriminate against interstate commerce, but rennanding to determine if purpose of cap was to discriminate, in which case the per se test would be applicable); Environmental Waste Reductions, Inc. v. Reheis, 887 F. Supp. 1534 (N.D. Ga. 1994) (striking down Georgia Solid Waste Management Act's "Georgia need" restrictions, planning requirements, and transportation limitations based on geographic origin of biomedical waste under both per se and balancing tests).

69. AlA. CODE $\$ \S 22-30-1$ to -18 (1999). This statute also established a "cap" on the amount of hazardous waste that could be disposed of in the state in any one year (100,000 tons). The Emelle facility was the only commercial hazardous waste facility in Alabama. In 1989, it receivcd 788,000 tons of waste, $90 \%$ of which came froin other states. See Chemical Waste Management, Inc. v. Hunt, 504 U.S. 334, 338 (1992). Thus, the statute was clearly designed to limit waste from other states.

70. See Hunt v. Chemical Waste Management, Inc., 584 So. $2 d 1367$ (Ala. 1991). The trial court found the base fee and cap to be constitutional, but the additional fee to be in violation of the Commerce Clause because the only reason for the difference in the fees was the origin of the waste. The Alabama Supreme Court found no aspect of the statute to be a Commerce Clause violation because the additional fee advanced a local purpose that could not be adequately addresscd by a nondiscriminatory alternative.

71. 504 U.S. 334 (1992).

72. See id. Alabama argued that the additional fee served the legitimate local purpose of protecting its citizens' health and safety. The Court rejected this argument not because of a lack of legitinate local interest, but because "Alabama targets only intcrstate hazardous waste to ineet these goals." Id. at 343 . The Court also found that there was no difference in the danger of out-of-state waste vis-à-vis in-state waste. See id. at 344-45. The Court rejected the argument that the statute was permissible as a "quarantine," as it did in Philadelphia v. New Jersey, finding that the out-of-state waste posed no additional threat to health and safety not found in in-state waste. See id. at 347-48.

73. See Fort Gratiot Samitary Landfill, Inc. v. Michigan Dep't of Natural Resources, 504 U.S. 353, 357 (1992) (decided the same day as Chemical Waste Management). 
the Sixth Circuit found a Commerce Clause violation. ${ }^{74}$ However, in Fort Gratiot, the Supreme Court held that the Michigan waste import restrictions were a per se violation of the Commerce Clause, ${ }^{75}$ rejecting Michigan's argument that its waste import restrictions did not discriminate because waste from other Michigan counties was treated the same as out-of-state waste. ${ }^{76}$ Other statutes like Michigan's met with similar fates in the courts. ${ }^{77}$

Still, the Chemical Waste Management and Fort Gratiot decisions did not extinguish all hope for state and local governments seeking to preserve landfill capacity. In Chemical Waste Management, the Court hinted that a tax on out-of-state waste might be valid if it were based on the actual (demonstrably higher) cost of disposimg waste from other states. ${ }^{78}$ States and localities could also find solace in the dissent of Justice Rehnquist in Chemical Waste Management, in which he pointed to the "market participation doctrine" as a means by which a state could avoid a Commerce Clause challenge. ${ }^{79}$ As the name implies, the doctrine states that when the state or local government is a market participant-if it owns and runs its own facility-it can deal with (and ban) whatever waste it sees fit. However, those states and local governments that tried to follow Justice

74. See Bill Kettlewell Excavating, Inc. v. Michigan Dep't of Natural Resources, 732 F. Supp. 761 (E.D. Mich. 1990) (dismissing complaint), aff'd, 931 F.2d 413 (6th Cir. 1991). The Sixth Circuit found (1) no facial discrimination because in-state and out-of-state waste were treated the same (counties could exclude both), and (2) that there was no actual discrimination because there was no allegation that all Michigan counties ban out-of-state waste.

75. See Fort Gratiot, 504 U.S. at 358. Interestingly, the Court (per Justice Stevens) emphasized a distinction that has become increasingly important in later waste regulation cases-the distinction between publicly owned facilities and privately owned and operated landfills. As the Court stated, "[n]or does the case raise any question concerning policies that municipalities or other governmental agencies may pursue in the management of publicly owned facilities. The case involves only the validity of the waste import restrictions as they apply to privately owned and operated landfills." Id. at 358-59; see also infra notes 97-102 and accompanying text.

76. See Fort Gratiot, 504 U.S. at 361. The Court concluded that the county's ability to prohibit out-of-state waste had the same effect as a state-wide ban. The Court also rejected the argument that a distinction should be made from the New Jersey ban because the regulation allowed other counties to accept out-of-state waste. See id. at 363.

77. See BFI Medical Waste Systems v. Whatcom County, 983 F.2d 911 (9th Cir. 1993) (overturning ordinance that banned out-of-county infectious medical waste from being disposed within the county); Southeast Ark. Landfill, Inc. v. Arkansas Dep't of Pollution Control and Ecology, 981 F.2d 372 (8th Cir. 1992) (reversing district court's refusal to enjoin the operation of a statute virtually identical to the Michigan statute).

78. See 504 U.S. at 346 n.9. Indeed, Chief Justice Rehnquist, in his dissent, concluded that the Alabama fee was not discriminatory:

Taxes are a recognized and effective means for discouraging the consumption of scarce commodities-in this case the safe environment that attends appropriate disposal of hazardous wastes.... I therefore see nothing unconstitutional in Alabama's use of a tax to discourage the export of this commodity to other States, when the commodity is a public good that Alabama has helped to produce.... Nor do I see any significance in the fact that Alabama has chosen to adopt a differential tax rather than an outright ban.

Id. at 349 (Rehnquist, C.J., dissenting).

79. Id. at 351 . 
Rehnquist's suggestions met with little success. ${ }^{80}$ The Eleventh Circuit decision in GSW, Inc. v. Long County, Georgia ${ }^{81}$ struck down one of the first attempts to avoid Commerce Clause problems by invoking the market participant theory. ${ }^{82}$ Similarly, the Supreme Court struck down the state of Oregon's attempt to impose a differential tax on out-of-state waste, concludimg that the state had not adequately justified the tax. ${ }^{83}$

As the Supreme Court gradually closed the door on import restrictions as a local waste management tool, states and localities turned to another waste management alternative-waste flow controls. Rather than attempt to preserve dwindling landfill capacity, some local governments built new waste disposal and management facilities, including waste incinerators, transfer stations, recycling facilities, and the like. ${ }^{84}$ Many of these local governments contracted for privately owned facilities and compensated the private facility owner based on the amount of waste delivered to the

80. See id. Rehnquist was correct in predicting that these decisions would produce more litigation in this area:

But certainly we have lost our way when we require States to perform such gymnastics, when such performances will in turn produce little difference in ultimate effects. In sum, the only sure byproduct of today's decision is additional litigation. Id. at 351 .

81. 999 F.2d 1508 (11th Cir. 1993).

82. After contracting with the plaintiff to build a private solid waste facility, the county attempted to limit the origin of the waste accepted by the plaintiff to within 150 miles of the county. The court found that the contract with the plaintiff and the county did not fall within the market participant exception primarily because the county had not invested or risked any public funds to build the facility. See id. at 1513. But see Eastem Ky. Resources v. Fiscal Court of Magoffin County, 127 F.3d 532 (6th Cir. 1997), cert. denied, 118 S. Ct. 1512 (1998), in which the state rejected a County's waste management plan that included a contract with plaintiff to develop a landfill that would accept out-of-state waste, but accepted a resubmitted plan that proposed to dispose of the county's waste outside the county. The Sixth Circuit found that the challenged provisions of Kentucky's Waste Management Program had neither discriminatory purpose nor effect, and that the benefits to the state (a good solid waste program to provide for the health and welfare of Kentucky's residents) outweighed any burden on interstate commerce. The court distinguished GSW Inc. because the county in GSW admitted that it sought to restrict out-of-connty waste. See id. at 544 n.4. As the court stated: "There is no evidence in the record that the [state] objected to the fact that [the plaintiff] planned to accept outof-state waste." Id. at 545.

83. See Oregon Waste Systems, Inc. v. Department of Envtl. Quality Comm'n of Or., 511 U.S. 93 (1994). In 1989 the Oregon legislature had imposed a "surcharge" on out-of-state waste. The amount of the charge was to be determined by the Environmental Quality Commission "based on the costs to the State of Oregon and its political subdivisions of disposing of solid waste generated out-ofstate whiclı are not otherwise paid for under specified statutes." Though the Oregon Court of Appeals and the Oregon Supreme Court upheld the surcharge, the Supreme Court rejected the argument that the Oregon statute imposed a "compensatory tax," noting that Oregon was unable to identify the intrastate tax burden that it was attempting to compensate. See id. at 96-97.

84. For discussions of the proliferation of privately owned waste facilities, see John Turner, The Flow Control of Solid Waste and the Commerce Clause: Carbone and its Progeny, 7 VILL. ENvTL. L.J. 203 (1996); Sidney M. Wolf, Congressional Bailout of Flow Control: Saving the Burning Beast, 7 VILL. EnVTL. L.J. 263 (1996); and James E. McCarthy, Solid Waste Issues in the I06th Congress (Feb. 18, 1999) (visited Apr. 2, 1999) <http://www.cnie.org/nle/waste-27.html> (chronicling the replacement of landfills with waste incinerators). 
facility. ${ }^{85}$ Under this kind of arrangement, one way for local governments to reduce disposal costs is to guarantee the owner of the waste facility a minimum daily delivery of waste. ${ }^{86}$ The guarantee takes the form of a waste flow control ordinance that requires haulers to take any waste collected within the boundaries of the locality to a specified waste facility. ${ }^{87}$

The town of Clarkstown, New York, adopted a flow control ordinance that required all solid waste collected in the town to be sent to a particular transfer station before being shipped out of the mumicipality. ${ }^{88}$ Carbone, a waste recycler, was discovered shipping household waste directly to a landfill in Indiana in violation of the ordinance.$^{89}$ After a series of actions in both New York and federal courts, ${ }^{90}$ the Supreme Court struck down the ordinance in Carbone, Inc. v. Town of Clarkstown. ${ }^{91}$ The Court concluded that the ordinance penalized waste recyclers like Carbone, requiring them to send the nonrecyclable portion of their wastes to the city's chosen facility rather than out-of-state, thereby increasing their costs. ${ }^{92}$ Thus, the

85. A typical arrangement is for the facility owner to charge a per-ton "tipping fee" to those who bring waste to the facility. Local governments often wish to keep this fee low, either hecause they pay this fee directly or because they wish to keep rates low for their (voting) constituents. Consequently, local governments have an incentive to negotiate the tipping fee arrangement with the facility owner before the contract is finalized.

86. This guaranteed minimum enables the facility owner to take advantage of economies of scale, and to pass those cost savings on to the local government in the form of a lower per-ton disposal fee.

87. See Tumer, supra note 84; Wolf, supra note 84 ; McCarthy, supra note 84.

88. The cost of building the transfer station was $\$ 1.4$ million. A private operator agreed to build the facility and run it for five years, after which the town would buy it for $\$ 1$. During the five years, the town guaranteed a minimum waste flow of 120,000 tons per year. The operator could charge the waste hauler a tipping few of $\$ 81$ per ton (this amount exceeded the disposal costs on the private market). The ordinance required all nonhazardous solid waste within the town to be deposited at the transfer facility. Noncompliance was punishable by a fine of up to $\$ 1000$ and up to fifteen days in jail. See C \& A Carbone, Inc. v. Town of Clarkstown, 511 U.S. 383, 387 (1994).

89. Carbone was discovered shipping the waste to another facility without going through the town's facility when a tractor-trailer with twenty-three bales of solid waste hit an overpass on the Palisades Parkway. The Clarkstown police put the Carbone facility under surveillance and caught six more trucks leaving the facility on their way to out-of-state disposal sites. See id. at 388.

90. The procedural history of this litigation is complicated. The city sued Carbone in the New York Supreme Court for an injunction to require Carbone to ship waste to the city's facility. Carbone sued the city in the federal district court to enjoin the flow control ordinance. The federal court granted the injunction and found that there was a sufficient basis for the ordinance to be declared in violation of the Commerce Clause. See 770 F. Supp. 48 (S.D.N.Y. 1991). Immediately thereafter the New York court granted summary judgment to the city. This court declared the ordinance constitutional and ordered Carbone to comply. The federal court then quashed its injunction. The New York Appellate Division affirmed finding that the ordinance did not unconstitutionally discriminate against interstate commerce because it applied to all waste processed within the city regardless of origin. See Carbone, 511 U.S. at 388-89 (citing 587 N.Y.S.2d 681, 686 (1992)). The New York Court of Appeals denied Carbone's motion for leave to appeal and the U.S. Supreme Court granted certiorari. See id. at 389.

91. 511 U.S. 383 (1994).

92. See id. at 389 . In addition, by seleeting one favored operator, the city was depriving out-ofstate businesses access to the local market. Either of these interstate economic effects was enough to invoke the Commerce Clause. See id. 
ordinance discriminated against interstate commerce and constituted a per se violation of the Commerce Clause..$^{93}$

Local governments have gone to great lengths to circumvent the Carbone decision, just as they did after Philadelphia v. New Jersey. The Eighth and Second Circuits have decided many of the resulting cases. ${ }^{94}$ While the Supreme Court has not yet addressed the validity of any of these recent approaches, the lower court decisions leave hittle hope for local governments seeking to regulate the flow of waste im the private market, and a great deal of hope for local governments willing to control the flow of waste by entering the market themselves. Typical of the first line of cases addressing private market regulation is Ben Oehrleins \& Sons \& Daughters, Inc. v. Hennepin County, ${ }^{95}$ in which the Eighth Circuit overturned a county ordinance requiring most waste generated within the county to be disposed of in county-designated facilities. ${ }^{96}$ National Solid

93. The Court stated:

The essential vice in laws of this sort is that they bar the import of the processing service.... The flow control ordinance... hoards solid waste, and the demand to get rid of it, for the benefit of the preferred processing facility. The only conceivable distinction from the cases cited above is that the flow control ordinance favors a single local proprietor. Bnt this difference just makes the protectionist effect of the ordinance more acute.

Id. at 392. The Court found that the city had a number of nondiscriminatory alternatives to assure the proper disposal of the waste, most notably safety regulations applicable to all disposers. See id. at 393.

94. There was activity in courts in this and other circuits as well. See, e.g., Connecticut Carting Co. v. Town of East Lyme, 946 F. Supp. 152 (D. Conn. 1995) (tipping fee unconstitutional under Carbone); Southcentral Pa. Waste Haulers Ass'n v. Bedford-Fulton-Huntingdon Solid Waste Auth., 877 F. Supp. 935 (M.D. Pa. 1994) (flow control ordinance with tipping fee unconstitutional under Carbone); see also Barker Brothers Waste, Inc. v. Dyer County Legislative Body, 923 F. Supp. 1042 (W.D. Tenn. 1996) (holding bidding process not protectionist even though one of the criteria was viability of county landfill; court also found that even if bidding process were protectionist it would not matter because county is nuarket participant).

95. 115 F.3d 1372 (8th Cir. 1997).

96. See id. at 1385; see also Waste Sys. Corp. v. County of Martin, 985 F.2d 1381 (8th Cir. 1993) (holding that the county ordinances, enacted pursuant to the Waste Management Act, which required all conpostable solid waste to be transported to the local composting facility, wcre per se invalid); National Solid Waste Management Ass'n v. Williams, 877 F. Supp. 1367, 1374 (D. Minn. 1995) (holding that an elaborate flow control statute, although facially neutral, had a discriminatory effect and was subject to the per se rule). But cf. Waste Management of Mich. v. Ingham County, 941 F. Supp. 656, 666 (W.D. Mich. 1996) (holding that transportation restrictions and county plan did not discriminate agaimst Interstate Commerce on their face or in practical effect). The Third Circuit has also dealt with flow control ordiuances, indicating its belief that uot all are per se invalid. See Atlantic Coast Demolition \& Recycling, Inc. v. Board of Chosen Freeholders of Atlantic County, 112 F.3d 652, 667 (3d Cir. 1997) ("[T]he State of New Jersey cannot protect the local waste disposal market, and thereby exclude out-of-state competitors, in order to use inflated revenues to finance the substantial debts of its waste management districts."); Harvey \& Harvey, Inc. v. County of Chester, 68 F.3d 788 (3d Cir. 1995) (finding flow control ordinance did not offer out-of-state landfill operators eqnal opportunity to compete for county's waste business aud thus discriminated against inter-state commerce); Atlantic Coast Demohtion \& Recycling, Inc. v. Board of Chosen Freeholders of Atlantic County, 48 F.3d 701, 718 (3d Cir. 1995) (findiug flow control ordinances discriminated against interstate commerce in purpose and effect, and renuanding case to district court to apply the strict scrutiny test under Carbone) [hereinafter Atlantic Coast I]; Waste Management of Pa., Inc. v. Shinn, 938 F. Supp. 1243 (D.N.J. 1996) (holding New Jersey's policy of insuring self-sufficient waste disposal discriminated against 
Waste Management Ass'n v. Williams, ${ }^{97}$ is illustrative of the second line of cases, which deal with the market participation exception. In that case, the challenged statute required public entities choosing to engage in the collection and disposal of waste to comply with the county's solid waste inanagement plan. ${ }^{98}$ The district court upheld the statute under the inarket participation exception, ${ }^{99}$ and the Eighth Circuit affirmed. ${ }^{100}$ The Second Circuit has also been receptive to the market participation exception, ${ }^{101}$ while the Eleventh Circuit has been less so. ${ }^{102}$

Thus Commerce Clause preemption jurisprudence remains far from settled. In her concurrence in Carbone, Justice O'Connor suggested that a possible solution to the confusion over the constitutionality of waste regulation lies in congressional action. ${ }^{103}$ That action, however, has not been forthcoming. In the 105th Congress, bills regulating interstate waste transfers were introduced, but none were enacted. ${ }^{104}$ As of this writing, renewed efforts are underway in the 106th Congress. ${ }^{105}$

interstate commerce and enjoined New Jersey from enforcing the policy); Atlantic Coast Demolition \& Recycling, Inc. v. Board of Chosen Freeholders of Atlantic County, 931 F. Supp. 341 (D.N.J. 1996) (holding that the county had not met its burden of showing that it lacked nondiscriminatory alternatives under the heightened scrutiny test) [hereinafter Atlantic Coast II].

97. 966 F. Supp. 844 (D. Minn. 1997).

98. See id. at 847 . The statute also defined "public entity" to include anyone contracting with a public entity. MINN. STAT. § 16B.122(1)(f) (1994).

99. See id. at 852; see also Gary D. Peake Excavating, Inc. v. Town Board of Hancock, 93 F.3d 68 (2d Cir. 1996) (upholding flow control ordinance that required any waste dumped in the town to be disposed of at towu-operated transfer station, but did not prevent town residents from disposing of waste at an out-of-town facility or any out-of-town coinpetitor from entering the market).

100. See Natioual Solid Waste Management Ass'n v. Williams, 146 F.3d 595 (8th Cir. 1998). The Seventh Cireuit, by contrast, has held that when a state imposes requirements on local government, it is acting as a market regulator and not a participant. See W.C.M. Wimdow Co. v. Bernardi, 730 F.2d 486 (7th Cir. 1984). The Third Circuit, however, found "no compelliug analytical difference betweeu a local governmeut unit and central state ageucies." Trojan Tech., Inc. v. Pennsylvania, 916 F.2d 903, 911 (3d Cir. 1990).

101. See SSC Corp. v. Town of Smithtown, 66 F.3d 502 (2d Cir. 1995) (upholding the creation of a residential garbage collection district and a contract with a local hauler to provide the service); USA Recycling, Inc. v. Town of Babylou, 66 F.3d 1272 (2d Cir. 1995) (upholding the town's takeover of the commereial garbage market because the town's waste management system treated in-state and out-ofstate garbage haulers alike in that all were excluded); see also Sal Tinnerillo \& Sous, Inc. v. Town of Stonington, 141 F.3d 46 (2d Cir. 1998); Houlton Citizens Coalition v. Town of Houlton, 982 F. Supp. 40 (D. Me. 1997).

102. See Waste Recycling, Inc. v. Southeast Ala. Solid Waste Disposal Auth., 814 F. Supp. 1566 (M.D. Ala. 1993), aff'd sub nom. Waste Recycling v. Southeast Ala. Solid, 29 F.3d 641 (11th Cir. 1994), in which that court rejected the application of the market participation exception in a garbage collection contract much like the oue in Smithtown. The Eleventh Circuit held that the town was not motivated by a proflt motive and had no proprietary interest $m$ garbage. See id. at 1573, 1576.

103. See 511 U.S. at 410 ("It is within Congress's power to authorize local impositiou of flow control. Should Congress revisit this area, and enact legislation providing a clear indication that it intends States and localities to inplement flow control, we will, of course, defer to that legislative judgmeut.").

104. The Senate bills are S. 463, 105th Cong. (1997); S. 448, 105th Cong. (1997); S. 443, 105th Cong. (1997); and S. 384, 105th Cong. (1997). The House bills are H.R. 2654, 105th Cong. (1997); H.R. 1358, 105th Cong. (1997); H.R. 1346, 105th Cong. (1997); and H.R. 942, 105th Cong. (1997). 


\section{B. Supremacy Clause Jurisprudence}

Modern Supremacy Clause and Commerce Clause preemption jurisprudence are similar in many respects. Both often involve attempts by local governments to exclude or regulate environmental, health, or safety hazards within their borders, and both lead to sharp disagreements among the courts over the constitutionality of those attempts. They differ, however, in one very basic way: Under the Supremacy Clause, the courts look for congressional intent to preempt state or local regulation in a prior legislative action; under the Commerce Clause, state or local law may be preempted in the absence of any congressional action. Thus, Supremacy Clause preemption cases turn on questions of statutory interpretation, and they produce (federal) statute-specific case law. ${ }^{106}$ But despite the relatively narrow questions at issue in Supremacy Clause cases, they have proven just as vexing to the courts as have Commerce Clause cases, and have produced an equally conflicted and fractured body of case law. ${ }^{107}$

When it established the modern federal regulatory system, Congress foresaw soine intergovernmental coordination problems and attempted to address them by including in federal statutes "preemption provisions," which specified how conflicts with state and local laws should be resolved. Some expressly preempt state and local regulation, while others contain so-called "savings clauses," which expressly reserve the right of states and localities to regulate environmental hazards. The conceptually neat distinction between express preemption provisions and savings clauses, however, belies a continuum of statutory provisions that evince varying (and sometimes vague) congressional intentions. Furthermore, even when a

Generally the bills allow states or local governments to restrict shipments of out-of-state waste, but would grandfather existing levels of out-of-state waste to a particular year. Also, the bills allow importing states to gradually reduce the levels of waste accepted. There are some differences, howevcr, between the proposed bills. The Senate bills authorize local governments to request that the governor restrict imports of waste, while the House bills authorize local governments to restrict waste shipments to local facilities. The House bills also contain a "presumptive ban" on new waste shipments unless the local government consented; under the Senate bills the waste shipments would be allowcd unless the governor stopped them. See James E. McCarthy, Solid Waste Issue in the 10Sth Congress (visitcd Aug. 14, 1998) <http://www.cnie.org/nle/waste-16.html>. Generally, these bills (H.R. 943, 105th Cong. (1997), S. 899, 105th Cong. (1997), and S. 443, 105th Cong. (1997)), would grandfather in flow control schemes in existence on May 15, 1994 (the day before Carbone). Currenily, according to EPA estimates, thirty-nine states and the District of Columbia have enacted some sort of flow control measure. At this time there has been no action on these bills.

105. See Pennsylvania Lawmakers Introduce Interstate Transport Bill with Flow Control, 29 Env't. Rep. (BNA) 2321 (1999); Robb, Warner Introduce Bill to Let States Limit Imports of Solid Waste, 29 Env't. Rep. (BNA) 2222 (Mar. 12, 1999).

106. This inay be one reason why Supremacy Clause cases are more numerous. More than half of the cases im our sample are Supremacy Clause cases, although the growing number of garbage disputes on the federal docket may change that distribution.

107. Perhaps as a partial consequence of the relatively narrow statutory interpretation issues involved in Supremacy Clause preemption disputes, the Supreme Court has been more successful in its attempts to resolve these conflicts when they arise. See infra Parts II.B.3, 5, 6. 
statute contains a relatively clear savings clause, courts may determine that the statute implicitly preempts state and local requirements that conflict with the federal regulatory scheme or that fall outside the scope of what the savings clause "saves." Hence this presents the opportunity for lower federal courts to read the statute narrowly in much the same way some read Supreme Court case authority narrowly in Commerce Clause preemption decisions.

For example, the Atomic Energy Act"108 ("AEA") and the Occupational Safety and Health Act ${ }^{109}$ ("OSHAct") establish what appear to be flexible yet precise systens for dividing regulatory authority between the federal government and the states. Each statute provides that only those states that have received formal approval from the jurisdictional federal agency ${ }^{110}$ - called "agreement states" under the $\mathrm{AEA}^{111}$ and "plan states" under OSHAct ${ }^{12}$ - may assume regulatory responsibility over the hazards covered by the statute. Each statute appears to establish a firm rule against state regulation absent this formal approval. ${ }^{113}$ However, some federal court decisions have permitted states and localities to exercise jurisdiction over these lazards without obtaining the formal approval required by the statutes. $^{114}$

108. 42 U.S.C. $\$ 2011-2297 \mathrm{~h}-13$ (1946). The Atomic Energy Act provides for the comprehensive regulation of nuclear energy and the creation of the Atomic Energy Commission, now called the Nuclear Regulatory Commission ("NRC").

109. OSHAct authorizes the Occupational Safety and Health Administration ("OSHA") to promulgate "standards" specifying how the goals of the statute are to be met in specific situations. These standards include both safety standards, governing the physical safety of employees, and health standards, regulating such things as airborne contaminants and the presence and handling of hazardous chemicals. See 29 C.F.R. pt. 1910 (1998).

110. The NRC, in the case of the AEA, and OSHA, in the case of the OSHAct.

111. 42 U.S.C. $\$ 2021(b)$.

112. 15 U.S.C. $\$ \S 651-678$.

113. The AEA provides: "Nothing in this section shall be construcd to affect the authority of any State or local agency to regulate activities for purposes other than protection against radiation hazards." 42 U.S.C. $\$ 2021(\mathrm{k})$ (emphasis added). The legislative history of this provision supports the conclusion that it conveys exclusive regulatory authority over radiation hazards to the NRC, and protects the rights of states to regulate non-radiation hazards. The Senate Report states that Section 2021(b) of the Act "is not intended to leave any room for the exercise of dual or concurrent jurisdiction by States to control radiation hazards ..." Sen. Rep. No. 870, 1959 U.S.C.C.A.N. 2872, 2879. Likewise, section 18 of the OSHAct states that "nothing in this act shall prevent any state agency or court from asserting jurisdiction under state law over any occupational safety and health issue with respect to which no standard is in effect under section 6 . . " 29 U.S.C. \$667(a) (emphasis added); see also 88 A.L.R. Fed. 833, 838-39; 29 C.F.R. $\$ 1910.1200$ (a)(2).

114. In the case of the AEA, some courts have let stand state or local requirements which are not explicitly aimed at radiological hazards, but which have the effect of regulating those hazards. Some of these laws are aimed primarily at regulating plant construction, others at environmental protection generally. See Illinois v. Kerr-McGee Chem. Corp., 677 F.2d 571 (7th Cir. 1982) (holding that the AEA does not preempt Illinois cnvironmental protection statute); Pacific Legal Found. v. State Energy Resources Conservation \& Dev. Comm'n, 659 F.2d 903 (9th Cir. 1982) (upholding state statute prohibiting nuclear plant construction absent nuclear waste disposal plans); Kerr-McGee Chemical Corp. v. City of West Chicago, 732 F. Supp. 922 (N.D. Ill. 1990) (ovcrturning city order halting 
Likewise, the Toxic Substances Control Act ${ }^{115}$ ("TSCA") appears to prohibit states from regulating PCB risks. ${ }^{116}$ However, this did not dissuade local governments from trying to ban or regulate PCB disposal and treatment. Some federal courts found their arguments persuasive; ${ }^{117}$ others

construction of nuclear plant). Other courts have continued to follow the traditional interpretation of the statute, which bars both purported and actual regulation of radiological hazards by states and localities. See Pacific Gas \& Elec. Co. v. State Energy Resources Conservation \& Dev. Comm'n, 489 F. Supp. 699 (E.D. Cal. 1980) (precmpting California statute rcgulating nuclear plant construction and waste disposal); Pacific Legal Found. v. State Energy Resources Conservation \& Dev. Comm'n, 472 F. Supp. 191 (S.D. Cal. 1979); United States v. City of New York, 463 F. Supp. 604 (S.D.N.Y. 1978) (preempting city siting ordinance for nuclear reactors); Northern States Power Co. v. Minnesota, $320 \mathrm{~F}$. Supp. 172 (D. Minn. 1970), aff'd, 767 F.2d 1234 (7th Cir. 1985) (explaining that the AEA preempts state pollution regulations governing radioactive releases).

With rcspect to OSHA health standards, some courts have overturned state and local regulations (or portions thereof) which overlap with OSHA health standards. See, e.g., National Solid Wastes Management Ass'n v. Killian, 918 F.2d 671 (7th Cir. 1990) (concluding that state statute governing training of hazardous waste site workers is preempted by analogous OSHA standard); New Jersey State Chamber of Commerce v. Hughey, 774 F.2d 587 (3d Cir. 1985) (holding that state right-to-know law was preempted "only in so far as it pertains to employee health and safety in the manufacturing sector); United Steelworkers v. Auchter, 763 F.2d 728 (3d Cir. 1985) (OSHA preempts state right-to-know law in so far as it applies to employees within the manufacturing sector); Environmental Encapsulating Corp. v. City of New York, 666 F. Supp. 535 (S.D.N.Y. 1987) (finding city asbestos regulations, including worker training provisions, precmpted by analogous OSHA standard). Other courts have elected to let stand state or local requirements whieh appear to overlap with OSHA health standards. See Ohio Mfrs. Ass'n v. City of Akron, 801 F.2d 824 (6th Cir. 1986) (city right-to-know ordinance not preempted by OSHA; local governments not covered by section 18, which applies to "states"); Associated Industries of Massachusetts v. Snow, 717 F. Supp. 951 (D. Mass. 1989) (explaining that state asbestos worker training requirements are not preempted by analogous OSHA standard because they serve additional purposes besides worker proteetion). This split ultimately prompted the Supreme Court to address the issue in 1991. The Court concluded that the OSHAct preempted state and local rules addressing hazards regulated at all by OSHA standards. See Wisconsin Publie Intervenor v. Mortier, 501 U.S. 597, 604 (1991).

115. 15 U.S.C. \$ $\$ 2601-2629$. Enacted in 1976, the TSCA asserts broad federal regulatory jurisdiction over existing and future ehemical substanees. Section $6(a)$ of the statute authorized the EPA to regulate a wide range of chemical activities that the agency determined would "prescnt an unreasonable risk of imjury to health or the environment." In addition, section 6(e) of the statute specifically directs the EPA to promulgate rules governing the disposal and labeling of polychlorinated biphenyls ("PCBs"). See 15 U.S.C. § 2605(a), (e) (1998). PCBs are commonly found in lubricating oils used in electrical equipment, including public utility electrical transformers and capacitors. Subsequently, the EPA promulgated rules governing the labeling of electrical cquipment containing PCBs, vehicles used to transport PCBs, as well as requirements for the disposal of PCBs and PCBcontaining electrical equipment. See 40 C.F.R. pt. 761 (1998).

116. Section 18 of TSCA provides that if the EPA regulates "a chemical substance or mixture" under section 6 of TSCA, any state regulation applicable to such substance or mixture" is preempled. 15 U.S.C. $\$ 2617$ (1998). This section makes an exception for (and therefore authorizes) a state or local regulation which is either identical to the federal requirement, is adopted under the authority of a federal law, or which prohibits entirely the use of the substanee within the state or locality. See id. Section 18 also excepts from this general rule disposal regulations promulgated under section 6(a)(6) of the statute. However, since all PCB regulations are authorized by section 6(e) of the statute, section 18 appears to prohibit state or local regulation of PCBs, including PCB disposal.

117. Some courts have interpreted TSCA to authorize state and local regulation of PCB disposal, concluding that PCB disposal regulations are among those described in seetion 6(a)(6), and are thereby exempted from the preemption provision. See City of Chesapeake v. Sutton Enterprises, Inc., 138 F.R.D. 468 (E.D. Va. 1990) (following the reasoning in Potomac Elec. Power Co. v. Sachs); Potomac 
did not. ${ }^{118}$ Nor have statutes containing savings clauses produced more consistent preemption decisions than statutes containing express preemption provisions. The Resource Conservation and Recovery Act $^{119}$ contains a savings clause expressly authorizing supplemental state regulation of hazardous wastes. ${ }^{120}$ Nevertheless, the comprehensiveness and specificity of the statute raise the possibility of implied preemption, and several state and local attempts to restrict hazardous waste disposal have been challenged on preemption grounds. The federal courts that have addressed this RCRA preemption question have been unable to reach a consensus, with some

Elec. Power Co. v. Sachs, 639 F. Supp. 856 (D. Md. 1986) (finding state PCB disposal regulations not preeunpted because they are of the type "described in" the section $6(\mathrm{a})(6)$ exception). Others have upheld local PCB regulation on other grounds. See Chappell v. SCA Services, Inc., 540 F. Supp. 1087 (C.D. Ill. 1982) (finding action to enjoin operation of PCB landfill not preempted by TSCA); SED, Inc. v. City of Dayton, Inc., 519 F. Supp. 979 (S.D. Ohio 1981) (explaining that although city's PCB regulations are not within the section $6(\mathrm{a})(6)$ exception, they are authorized under TSCA's explicit exception for regulations promulgated under the Clean Water Act).

118. See Rollins Envtl. Servs., Inc. v. Parish of St. James, 775 F.2d 627 (1985) (concluding that Parish ordinance regulating PCBs is preempted because the section $6(a)(6)$ exception does not apply); Twitty v. North Carolina, 527 F. Supp. 778 (E.D.N.C. 1981); Warren County v. North Carolina, 528 F. Supp. 276 (E.D.N.C. 1981), both aff'd, 696 F.2d 992 (4th Cir. 1981) (holding county ordinance banning PCB disposal is preempted by TSCA). The Rollins case presented Commerce Clause issues as well, and the court found the ordinance there violative of the Commerce Clause in so far as it amounted to an outright ban on PCB disposal. See 775 F.2d at 635. For its part, the EPA has actively supported the continuing validity of state and local PCB regulation, despite the fact that its own PCB regulations, including its disposal regulations, are explicitly promulgated under the authority of section $6(\mathrm{e})$ of the statute, and not section 6(a)(6) of the statute. See 43 Fed. Reg. 7150 (1978) ("These regulations prescribe disposal and marking requirements for polychlorinated biphenyls (PCBs), and are promulgated pursuant to section 6(e)(1) of the Toxic Substances Control Act."); see also 44 Fed. Reg. 31514 (1979). The EPA eventually rendered the issue noot by authorizing states and localities to regulate PCBs under the delegated authority of the Resource Conservation and Recovery Act ("RCRA"). See EPA Notice of the First Priority List of Hazardous Substances That Will Be Subject to Toxicological Profiles, 52 Fed. Reg. 12,866 (Apr. 17, 1987).

119. 42 U.S.C. $\$ \S 6901-6992 k$. RCRA was intended to provide federal "cradle-to-grave" regulation of hazardous waste. See Chicago v. Environmental Defense Fund, 511 U.S. 328, 331 (1994); C\&A Carbone, Inc. v. Town of Clarkstown, 511 U.S. 383, 408 (1994). Like the Clean Air Act and Clean Water Act before it, RCRA expressly provides for a significant state role in hazardous waste regulation. Section 3006(b) authorizes the delegation of authority to administer and enforce RCRA regulatory programs to the individual states. See 42 U.S.C. $\$ 6926$ (1994).

120. Section 3009 reads, in pertinent part:

[N]o state or political subdivision may impose any requirennents less stringent than those authorized under this subchapter .... Nothing in this chapter shall be construed to prohibit any State or political subdivision thereof from imposing any requirements, including those for site selection, which are unore stringent than those imposed by such regulations.

42 U.S.C. § 6929 (1994). 
courts permitting the restrictions ${ }^{121}$ and others finding them implicitly preempted by RCRA. ${ }^{122}$

We include three other bodies of statutory preemption jurisprudence in our analysis: those arising under the Federal Power Act ("FPA") of $1935,{ }^{123}$ the Hazardous Materials Transportation Act ("HMTA") of 1975, ${ }^{124}$ and the Federal Insecticide, Fungicide, and Rodenticide Act ("FIFRA"). ${ }^{125}$ Each has produced a set of lower federal court decisions that are difficult to reconcile. In the case of the FPA, ${ }^{126}$ a Supreme Court decision ${ }^{127}$ appeared to send a strong signal to states and localities that the FPA leaves no rooin for them to regulate hydroelectric facilities for environmental protection purposes. ${ }^{128}$ Yet, increasing political pressure to assert state and local authority over the environmental hazards posed by hydroelectric projects led several states and localities to challenge the FERC's absolute authority over hydroelectric facility regulation, ${ }^{129}$ and at least one such attempt was successful. ${ }^{130}$

121. See, e.g., LaFarge Corp. v. Campbell, 813 F. Supp. 501 (W.D. Tex. 1993) (concluding state statute prohibiting buming of fuel in certain locations not preempted by RCRA); North Haven Planning \& Zoning Comm'n v. Upjohn Co., 753 F. Supp. 423 (D. Conn. 1990), affd, 921 F.2d 27 (2d Cir. 1990) (concluding town regulation of sludge pile not preempted by RCRA); National Solid Wastes Managements Ass'n v. Alabama Dept. of Envtl. Management, 729 F. Supp. 792 (N.D. Ala. 1990) (holding statute prohibiting import of hazardous waste not preempted by RCRA).

122. See, e.g., ENSCO, Inc. v. Dumas, 807 F.2d 743 (8th Cir. 1986) (concluding local ordinance prohibiting storage, treatment, or disposal of "acute hazardous waste" implicitly preempted by RCRA); Ogden Envtl. Servs., Inc. v. City of San Diego, 687 F. Supp. 1436 (S.D. Cal. 1988) (finding city's demial of conditional use permit for waste facility implicitly preempted by RCRA). RCRA cases, like the TSCA preemption cases, present facts that often trigger Commerce Clause challenges as well; indeed, the very Alabama statute that the Eleventh Circuit overtumed on Commerce Clause grounds in National Solid Wastes Management Ass' $n$ v. Alabama Department of Environmental Management was upheld against a RCRA preemption challeuge in National Solid Wastes Management Ass'n v. Alabama Department of Environmental Management, 729 F. Supp. at 804-05.

123. 16 U.S.C. $\$ \S 791 \mathrm{a}-828 \mathrm{c}$.

124. 49 U.S.C. $\$ \S 5101-5127$.

125. 7 U.S.C. $\$ \S 136-136 y$ (1998), 40 C.F.R. $\$ \S 156-171$ (1998). FIFRA comprises a series of laws enacted in the 1970s that require pestieide manufacturers to register their products with the federal government, and that regulate pestieide labeling, packaging, sale, and use.

126. The FPA established the federal government's right to license and regulate hydroelcctrie power projects, ereated the Federal Energy Regulatory Commission ("FERC"), formerly called the Federal Power Commission, and granted FERC broad power to set the terms and conditions of hydroelectrie licenses. See 16 U.S.C. $\$ \$ 792-804$.

127. See First Iowa Hydro-Elec. Cooperative v. Federal Power Comm'n, 328 U.S. 152 (1946).

128. The First Iowa decision was based on an interpretation of section 27 of the statute, which provides that

[n]othing contained in this chapter shall be construed as affecting or intending to affect or in any way to interfere with the laws of the respective States relating to the control, appropriation, use, or distribution of water used in irrigation or for municipal or other uses, or any vested right acquired therein.

16 U.S.C. $\$ 821$ (1994).

129. States and localities seeking to regulate hydroelectric power projects for environmental protection purposes were emboldened by a 1978 Supreme Court decision which implied that the Supreme Court imight be willing to reverse First Iowa. In that case, California v. United States, 438 U.S. 645 (1978), the Supreme Court interpreted preemptive language from the Reclamation Act, 43 
The HMTA preempts inconsistent ${ }^{131}$ state and local regulation of hazardous materials transportation, ${ }^{132}$ but federal decisions assessing the consistency of local regulations with federal requirements have been inconsistent. ${ }^{133}$ Some federal courts have upheld state and local transportation regulations as consistent with HMTA requirements, ${ }^{134}$ while others have struck down nearly identical regulations as inconsistent with those same HMTA requirements. ${ }^{135}$

U.S.C. $\$ 383$, that was essentially identical to (and which served as the model for) section 27 of the FPA, concluding that the Reclamation Act did not preempt state and local regulation. Despite this argument, most federal courts adhered to the First Iowa precedent. See California v. Federal Energy Regulatory Comm'n, 877 F.2d 743 (9th Cir. 1989); Rivers Elec. Co., Inc. v. 4.6 Acres of Land Located in Catskill, 731 F. Supp. 83 (N.D.N.Y 1990) (preempting the New York State Energy Law, which regulated new power plants); Board of Elec. Light Comm'rs of Burlington v. McCarran, 563 F. Supp. 374 (D. Vt. 1982) (holding hydro licensing rules of the State Public Service Commission implicitly preempted), aff'd, 725 F.2d 176 (2d Cir. 1983); Town of Springfield v. McCarran, 549 F. Supp. 1134 (D. Vt. 1982) (rejeeting expressiy the argument that California v. U.S. implicitly reversed First Iowa); Town of Springfield v. Vermont Envtl. Bd., 521 F. Supp. 243 (D. Vt. 1981) (finding state land use permit requirement preempted as applied to hydro project).

130. See Mega Renewables v. County of Shasta, 644 F. Supp. 491 (E.D. Cal. 1986) (expressly accepting the argument that California v. U.S. imphicitly reversed First Iowa). Ultimately, the Supreme Court reaffirmed the preemptive effect of the statute. See California v. Federal Energy Regulatory Comm'n, 405 U.S. 490 (1990) (reaffirming the Court's holding in First Iowa).

131. See 49 U.S.C. $\$ 5125(a)$.

132. In the words of one court, the statute was enacted to provide uniformity in place of a "patchwork of sometimes conflicting state regulations." Jersey Cent. Power \& Light Co. v. Township of Lacey, 772 F.2d 1103, 1112 (3d Cir. 1985).

133. Under the HMTA scheme, any party can apply to the Department of Transportation ("DOT") for a formal determination whether a state or local requirement is consistent with federal regulations. See 49 U.S.C. $\$ 5125$ (1994). The criteria applied by the DOT in making consistency determinations is essentially the same as that applied by courts in deciding cases of conflict type implied preemption of state or local law by federal law (discussed supra note 33 and accompanying text). Until 1985, consistency determinations were made by the DOT"s Materials Transportation Board ("MTB"). The MTB's role was transferred to the DOT's Office of Hazardous Materials Transportation in 1985. See 50 Fed. Reg. 45,728 (1985). While the DOT is authorized to make consistency determinations, there is no statutory or other legal requirement that the DOT be given the opportunity to make initial consistency determinations, or that the DOT consistency decisions be given deference by the courts. See, e.g., Southeru Pac. Transp. Co. v. Public Serv. Comm'n of Nev., 909 F.2d 352 (9th Cir. 1990). In fact, aggrieved parties may bring HMTA preemption issues directly to the federal courts, bypassing the DOT process altogether. The courts may then apply the statutory consistency criteria in makiug those determinations without regard to the existence or substance of any prior DOT consistency determination. See National Tank Truck Carriers, Inc. v. City of New York, 677 F.2d 270, 274 n.5 (2d Cir. 1982).

134. See National Tank Truck Carriers, 677 F.2d at 270 (upholding city regulations governing transportation of gases); Colorado Pyrotechnic Ass'n v. Meyer, 740 F. Supp. 792 (D. Colo. 1990) (concluding city hazardous materials transportation regulations banning some materials from the city not preempted by HMTA); City of New York v. United States Dep't of Transp., 700 F. Supp. 1294 (S.D.N.Y. 1988) (holding city ban on transportation of nuclear waste preempted by HMTA); City of New York v. Ritter Transp., Inc., 515 F. Supp. 663 (S.D.N.Y. 1981) (holding city routing requirements for hazardous materials not preempted by HMTA).

135. See Colorado Pub. Utils. Comm'n v. Harmon, 951 F.2d 1571 (10th Cir. 1991) (striking down state record-keeping and permitting requirements); Southern Pac. Transp. Co. v. Public Serv. Comm'n of Nev., 909 F.2d 352 (9th Cir. 1990) (explaining state loading permit requirement for hazardous materials preempted by HMTA); Jersey Cent. Power \& Light Co. v. Township of Lacey, 772 F.2d 
Finally, while FIFRA ${ }^{136}$ provides for delegation of numerous regulatory functions to the states, ${ }^{137}$ it (1) prohibits states from imposing any "packaging or labeling" requirements "in addition to or different from" federal requirements, and (2) prohibits inconsistent state regulation of the sale or use of pesticides. ${ }^{138}$ Throughout the 1980 s and ' 90 s local communities provoked FIFRA preemption disputes by enacting "right-to-know" statutes and ordinances requiring pesticide applicators to provide additional information to those who may be affected by pesticide applications. Some federal courts struck down these local laws as preempted by FIFRA, while others upheld them. ${ }^{139}$

1103 (3d Cir.), cert. denied, 475 U.S. 1013 (1985) (finding town ordinance prohibiting the importation of spent nuclear fuel preempted by HMTA); Union Pac. R.R. v. City of Las Vegas, 747 F. Supp. 1402 (D.C. Nev. 1989) (concluding city hazardous materials transportation ordinance preemptcd); Consolidated Rail Corp. v. City of Bayonne, 724 F. Supp. 320 (D.N.J. 1989) (finding city limitation on rail transport of hazardous materials preempted by HMTA); National Tank Truck Carricrs, Inc. v. Burke, 535 F. Supp. 509 (D.R.I. 1982), aff d, 698 F.2d 559 (1st Cir. 1983) (holding state PUC rulcs governing transportation accident reports preempted); Atchison, Topeka \& Santa Fe R.R. Co. v. Illinois Commerce Comm'n, 453 F. Supp. 920 (N.D. Ill. 1977) (holding state railroad tanker regulations preempted).

136. 7 U.S.C. $\$ 136-136 y$ (1998); 40 C.F.R. $\$ \$ 156-171$ (1998).

137. See 7 U.S.C. $\$ 136 v(1994) ; 40$ C.F.R. $\$ 162$.

138. 7 U.S.C. $\S 136 \mathrm{v}$ (1994). The statute further defines "labeling" broadly to include "other written, printed or graphie matter" which accompanies the pesticide or to which the label refers. 7 U.S.C. $\$ 136(p)$.

139. The conflict centered on two issues. The first concerned the scope of the prohibition against state or local regulation of "labeling." Some courts read the prohibition (and, hence, FIFRA's preemptive effect) broadly. Other courts read the local labeling prohibition narrowly. Compare Chemical Specialties Mfg. Ass'n. v. Allenby, 744 F. Supp. 934 (N.D. Cal. 1990) (same holding as DCON Co. v. Allenby); D-CON Co. v. Allenby, 728 F. Supp. 605 (N.D. Cal. 1989) (finding California's Proposition 65, which requires any of several different forms of notice to be given when people are exposed to toxics, imcluding pesticides, not preempted because some of the Proposition 65 conpliancc methods do not constitute "labeling" under FIFRA); New York State Pesticide Coalition v. Jorling, 704 F. Supp. 26 (N.D.N.Y. 1989), aff'd, 874 F.2d 115 (2d Cir. 1989) (holding New York State pesticide information disclosure rules not preempted because they are "sale and use" rather than "labeling" requirements); and National Agric. Chem. Ass'n v. Rominger, 500 F. Supp. 465 (E.D. Cal. 1980) (finding California pesticide information disclosure rules not preempted by FIFRA), with Professional Lawn Care Ass'n v. Village of Milford, 909 F.2d 929 (6th Cir. 1990) (finding village ordinance regulating pesticide application and imposing notice requirements preempted by FIFRA); and Coparr, Lid. v. City of Boulder, 735 F. Supp. 363 (D. Colo. 1989) (holdiug local ordinance regulating commercial pesticide application preempted by FIFRA).

The second issue concerned whether FIFRA implicitly preempted all local government regulation by delegating only to "States" the authority to act. Again, some federal courts answered this question affirmatively. See Professional Lawn Care Ass'n, 909 F.2d at 931 (holdiug political subdivisions not included within definition of "state" under the statute); Maryland Pest Control Ass'n v. Prince George's County, 822 F.2d 55 (4th Cir. 1987), aff' 646 F. Supp. 109 (D. Md. 1986) (holding political subdivisions excluded from statutory definition of "state”); Maryland Pest Control Ass'n v. Montgomery Couuty, 646 F. Supp. 109 (D. Md. 1986) (concluding county ordinance imposing posting and notice requirements on apphicators is preempted because the couuty is not a "State" under FIFRA). Other courts concluded that local government regulation was not preempted. See Coparr, Ltd., 735 F. Supp. 363, 366-67. In 1991, the Supreme Court resolved both of these issues, ruling in favor of the authority of local goveruments (not just states) to regulate in accordance with FIFRA, and reading the statutory prohibition against non-federal "labeling" requirements narrowly to pcrmit state and local 


\section{Evaluations of Modern Preemption Doctrine}

Why have these two strains of preemption case law produced such an unusual degree of confusion and conflict? No doubt this is due in part to their common social and political context. Both sets of preemption conflicts embody a struggle to control the regulation of environmental, health, and safety risk that has consumed an enormous annount of resources and effort. Not surprisingly, preemption jurisprudence has provoked a great deal of comment, some favorable and some critical. Most of that comment is aimed at evaluating preemption doctrine, particularly Supreme Court decisions, not at explaining the conflicts within this jurisprudence. ${ }^{140}$ In a way, then, the scholarly literature reflects the federal jurisprudence, but focuses inore directly on the ideological and policy issues that drive these conflicts. In so doing, the literature offers some clues to the forces that affect the individual judges' decision which, as a whole, comprise this jurisprudeuce.

A great deal of scholarly criticism has been directed at the courts' apparent strategy of reserving the balance of regulatory power for the national government, ${ }^{141}$ one consequence of which has been to foster the growth of a national private market in waste. ${ }^{142}$ Soine critics note that with the development of state mterest in and capacity for regulation, much of the rationale for federal coordimation has vanished, ${ }^{143}$ and that modern preemption doctrine has strayed from the inore state-friendly conceptions of

information provision rules. See Wisconsin Pub. Intervenor v. Mortier, 501 U.S. 597 (1991) (upholding a local ordinance that imposed notice, permitting, and other requirements on pesticide applicators). This decision is unusual for at least two reasons. First, it is the only recent Supreme Court decision upholding the exercise of local police power in the context of environmental, health, and safety regulation. Second, unlike most Supreme Court preemption decisions, it was unanimous.

140. For a representative sample, see Kirsten Engel, Reconsidering The National Market in Solid Waste: Trade-Offs In Equity, Efficiency, Environmental Protection, and State Autonomy, 73 N.C. L. REv. 1481 (1995) (arguing Congress should act to allow states to enter interstate compacts responsible for solid waste disposal in multi-state areas as an alternative to the current national market); Daniel C. Esty, Revitalizing Environmental Federalism, 95 MicH. L. REv. 570 (1996) (arguing for a inulti-tier regulatory scheme based on the complexity of the environmental problem and against decentralization); Julian N. Eule, Laying the Dormant Commerce Clause to Rest, 91 Y ALE L.J. 425 (1982) (discussing the Supreme Court's role in preventing states from imposing unfair burden on out-of-state interests); Donald H. Regan, The Supreme Court and State Protectionism: Making Sense of the Dormant Commerce Clause, $84 \mathrm{MrCH}$. L. REv. 1091 (1986) (arguing the Court's role is to prevent protectionism); Revesz, Rehabilitating Interstate Competition, supra note 54 (arguing for a decentralized approach to environmental policy).

141. See Butler \& Macey, supra note 54, at 28-37, 42-45; Revesz, supra note 54, at 1211 n.3.

142. See Engel, supra note 140 , at 1484 (noting Supreme Court's determination that Commerce Clause requires national market in waste disposal is not binding on Congress); Robert R.M. Verchick, The Commerce Clause, Environmental Justice, and the Interstate Garbage Wars, 70 S. CAL. L. REv. 1239,1242 (1997) (stating that the Court's Commerce Clause decisions elevated free trade in waste over values of federalism, fairness and environmental faimess).

143. See Revesz, supra note 54, at 1227-33; see also Butler \& Macey, supra note 54 (arguing for decentralization of environmental policy decision making); Verchick, supra note 142, at 1245 (arguing that the Court's hard line approach is wrong). 
the founders. ${ }^{144}$ But while part of the scholarly debate over preemption jurisprudence turns on principles of federalism and policy preferences, ${ }^{145}$ much of it revolves around another, related ideological divide, one that is ubiquitous in environmental policy arguments. It concerns competing economic theories of how environmental, health, and safety problems should be addressed generally, irrespective of the particular policy issue involved. ${ }^{146}$

At the core of the debate lies a disagreement over the relative merits of privately negotiated, as against publicly imposed, solutions to NIMBY disputes and other attempts by communities to avoid environmental harm. Naturally, economists conceive of these kinds of disputes in cost-benefit terms. One view, often associated with economist A.C. Pigou, ${ }^{147}$ conceives of pollution and other industrial hazards as "external costs," or "externalities," that a firm or local political subdivision may try to shift to society at large. ${ }^{148}$ This analysis indicates the need for governmental action to "internalize" this social cost, through pollution control regulations or pollution taxes. ${ }^{149}$ The counterpoint to the Pigovian analysis is offered by Ronald Coase, who analyzed this situation somewhat differently. ${ }^{150}$ Coase demonstrated that, in the absence of impediments to bargaining between actors, the most efficient result, or the result that would maximize total social net benefits, would arise not from government intervention, but from

144. See, e.g., Gardbaum, The Nature of Preemption, supra note 21, at 783 ("Prior to the beginning of this century, concurrent state and fcderal power was 'genuine': that is, each sovcrcign possessed equal regulatory power subject only to the independent operation of the Supremacy Clause.").

145. See Stanley E. Cox, What May States Do About Out-of-State Waste in Light of Recent Supreme Court Decisions Applying the Dormant Commerce Clause? Kentucky as Case Study in the Waste Wars, 83 KY. L.J. 551 (1994-95).

146. For a general discussion of this ideological divide, see William F. Baxter, People or Penguins: The Case for Optimal Pollution (1974) (environmental problems are basically economic and would benefit from economic analysis); RICHARD B. STEWART \& JAMES E. KRIER, ENvironmental LAW AND POLICY (1978) (setting forth economic framework for analysis of environmental problems).

147. See A.C. Pigou, The Economics of Welfare 134 (1st ed. 1920).

148. See id. at 183-88. These are sometimes also referred to as "social costs," though that term is also used to refer to total internal and external costs as well. Most environmental economics texts contain good descriptions of Pigou's ideas. See, e.g., William J. Baumol \& Wallace E. OAtes, Economics, Environmental Policy, and the Quality of Life 21-47 (1979); David W. Pearce \&

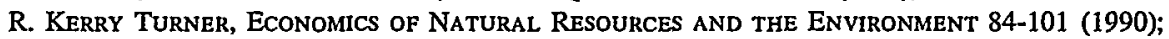
Thomas H. Tietenberg, Environmental Economics and Policy 372-75 (1998).

149. Environmental economists, Pigou included, have long argued that taxes or marketable permits will accomplish this goal more efficiently than regulation. This is because it will be difficult for regulators to determine the optimal (or net benefit maximizing) amount of pollution control. By contrast, taxes and marketable permits rely on individual firms to make their own detcrminations of the relative benefits of controlling pollution versus the costs (in taxes or permits purchased) of polluting. For a helpful discussion of this issue and its complexities, see BAUMOL \& OATES, supra note 148, at 346-66.

150. See R.H. Coase, The Problem of Social Cost, 3 J. LAw \& Econ. 1 (1960). 
private negotiation. ${ }^{151}$ The Coasean analysis implies that, where one party's pollution or waste injures another party, government intervention requiring the polluter to internalize those externalities would inore than likely be inefficient, or relatively so. ${ }^{152}$ This is because the true value the parties place on those externalities will be more accurately gauged by their willingness to pay each other to accept or stop the pollution than by government's attempts to measure those values. ${ }^{153}$

These economic theories have found their way into modern preemption conflicts, in spirit if not in name. For example, the TSCA preemption provision has a Pigovian element to it in that it permits local governments to ban PCB disposal within their borders only if those local governments also ban the use of PCBs. ${ }^{154}$ In this way, the statute discourages local

151. See id. at 2-15. Coase's basic argument contained several important and oft-ignored qualifiers. The first is that Coase's sole evaluative criterion is the standard economist's goal of maximizing social net benefit, measured in dollars. He contended that the privately negotiated solution will impose the fewest total costs, thereby maximizing the net benefits to society. Thus, the party who values the polluting activity more highly will pay the other to accept the cost of pollution. Government action to allocate liability will tend to be less efficient, in this sense. Thus, Coase's analysis ignores other dimensions of fairness, sucl as the question of whether the polluter came to the injured party or the injured party came to the polluter, or the effects of distribution of wealth on willingness to pay, and more. See id. at 15; see also infra notes 163-69 and accompanying text. Second, Coase's argument holds only in the absence of transaction costs in bargaining. Where multiple parties are affected by pollution from a single firm, the injured parties may have difficuity acting collectively, which can lead to inefficient results. See Coase, supra note 150, at 17. As others have observed, the incentive to "free ride" can undermine that conclusion eveu when multiple affected parties can overcome other obstacles to bargaining. See RuSSEll HARdiN, Collective Action 182, 212 (1982); TOdD SANDLER, COllective Action: TheORIEs AND PRoBlems 47, 54-56 (1992); see also Avinash Dixit \& Mancur Olson, Does Voluutary Participation Undermine the Coase Theorem? (1997) (unpublished manuscript, University of Munich Center for Economic Studies Working Paper No. 139) (attempting to integrate the Coase theorem with political collective action problems).

152. See Coase, supra note 150 , at $8-15$. The relative efficiency of the market over governmental action is a virtual article of faith among economists and is supported by the works of other economists purporting to demonstrate the arbitrariness of governmental action. See, e.g., KenNeTH J. ARROW, Social Choice and Individual Values (1963) (demonstrating the inability of collective choices to satisfy certain democratic values); MANCuR Olson, JR., The Logic of Collective Action (1965) (arguing that political processes systematically underrepresent certain societal interests).

153. See Coase, supra note 150 , at $2-8$. The Coasean approach is reflected in various compensation schemes offered as proposed solutions to siting problems. See, e.g., Frey \& OberholzerGee, supra note 57; Howard Kunreuther \& Doug Easterling, The Role of Compensation in Siting Hazardous Facilities, 15 J. PoL'y ANALysis \& MGMT. 601 (1996). For a discussiou of the problems associated with compensation schemes, see Been supra note 55, at 1040-46. However, William Baumol and Wallace Oates contend that compensating victims can create the incentive for strategic behavior that distorts the market. See BAUMOL \& OATES, supra note 148, at 23.

154. See 15 U.S.C. $\$ 2617($ a)(2)(B)(iii) (1998). This same concern was echoed in a TSCA preemption opinion:

In the past several months, EPA has become concerned that actions by local and State governments to prohibit disposal of PCBs and other substances in their jurisdictions could frustrate the national goal of properly disposing of hazardous chemical substances.

Warren County v. North Carolina, 528 F. Supp. 276, 289 (E.D.N.C. 1981) (citation omitted). Likewise, FIFRA authorizes states to ban the use of all pesticides, but does not permit states to selectively regulate pesticides except in accordance with federal gnidelines. See 7 U.S.C. $\$ \S 136 \mathrm{v}, 136 \mathrm{w}$ (1994); 40 C.F.R. $\$ 162$ (1998). 
governments from simultaneously shifting the cost of disposal to others while retaining the benefits of PCB usage. Similarly, Commerce Clause prohibitions against banning the importation of environmental hazards are consistent with the Coasean prescription in that they encourage private, market-driven solutions to waste disposal problems. In another sense, these local attempts to ban importation of waste may also be anti-Pigovian if they represent an attempt to ban waste disposal in the community altogether, including locally generated waste. On the other hand, as we have seen, ${ }^{155}$ soine states have attempted (most of thein unsuccessfully) to answer that charge by crafting Pigovian regulations that not only prohibit the local importation of waste, but force their local citizens to bear the disposal costs associated with the waste they generate.

Much of the scholarly commentary on modern preemption doctrine is split along this "Coase vs. Pigou" fault line, and mueh of it explores the ethical implications of the issue. The critique is often stated in Pigovian terms. ${ }^{156}$ Scholars have explored some of the practical miplications of preemption doctrine, noting that the national, private inarket for waste disposal sends waste down "the path of least resistance."157 That path travels froin the richer, urban states to the poorer, rural states where disposal costs are lower. ${ }^{158}$ This result raises obvious equity concerns. ${ }^{159}$ Critics argue that it is unfair for poorer states to become dumping grounds for richer ones. ${ }^{160}$ Because poorer states have relatively inore lax environinental standards

155. See supra Part II.A, especially Fort Gratiot Sanitary Landfill, Inc. v. Michigan Dep't of Natural Resources, 504 U.S. 353, 355-57, 361-68 (1992) (discussing Michigan waste management statute). Interestingly, Chief Justice Rehnquist in his Fort Gratiot dissent, made the Pigovian argument quite foreefully: "The State of Michigan has stepped into [the waste] quagmire in order to address waste problems generated by its own populace. It has done so by adopting a comprchensive approach to the disposal of solid wastes generated within its borders." Id. at 369. Rehnquist viewed the Michigan statute not as economic protectionism, but as an attempt by a state to accept responsibility for its waste problein without becoming "the waste repositor[y] for [its] brethren, thereby suffering the many risks that sucli sites present." Id. at 373. Chief Justice Rehnquist's dissent in Chemical Waste Managentent, Inc. v. Hunt, 504 U.S. 334, 349 (1992), was also expressed in Pigovian terms.

156. See, e.g., Engel, supra note 140, at 1518-21; Oates, supra note 54, at 14.

157. Engel, supra note 140, at 1495.

158. See id. at 1494 ("On average, the annual per capita income of residents in waste-importer states is $\$ 1,170$ less than im exporter states.").

159. See, e.g., Stanley E. Cox, Garbage In, Garbage Out: Court Confusion About the Dormant Commerce Clause, 50 OKLA. L. REv. 155, 220 (1997) (arguing for state and local regulation because the unfettered free inarket may produce injustice as well as health and safety problems for the populace); Verchick, supra note 142, at 1309 (arguing that state and local waste regulations can be used to further the environmental justice cause by reflecting conccrn for fairness, political inelusion, and ecology).

160. These ethical arguments are sometimes framed using John Rawls' difference principle. See, e.g., Been supra note 55, at 1048-53; Engel, supra note 140, at 1526; see also Russell B. Korobkin \& Thomas S. Ulen, Efficiency and Equity: What Can Be Gained By Combining Coase and Rawls (Mar. 1998) (unpublished manuscript, on file with authors). 
and actual enforcement, ${ }^{161}$ waste travels to the destination where it will do the most harm to the environment, all else being equal. ${ }^{162}$

Not surprisingly, the rejomder by defenders of the current preemption doctrine tends to be stated in Coasean terms. ${ }^{163}$ They ask "why shouldn't waste take the path of least resistance?" 164 In a private market, these social costs will be imposed on those who are most willing to accept them, as evidenced by lower disposal costs in those states. ${ }^{165}$ Those costs, after all, reflect in part the lower population density of inporting states, which in turn means that social costs (impacts to humans) will be lower, not

161. Engel notes that landfill standards in waste inporting states tend to be more lax than in exporting states. As these standards become federalized under RCRA subtitle $D$, that may change. However, as Engel also notes, federal standards cannot overcoine disparities in the ability or willingness of states to enforce those standards. See Engel, supra note 140, at 1489.

162. See Daniel C. Esty, Revitalizing Environmental Federalism, 95 MrCH. L. Rev. 570, 653 (1996) (arguing against hoth a centralized environinental regulatory scheme and a localized one, in favor of a multi-tier system that will lead to greater social welfare gains).

163. We should acknowledge that while it is common to describe a wide variety of nongovernmental and market-based prescriptions as "Coasean," that practice is perhaps not fair to Coase. As we discussed earlier, Coase makes no clain that his efficiency argument applies under conditions other than those he posits. See supra note 151. Further, he has not (so far as we know) argued that his carefully-constructed conditions apply to the interstate movement of externalities.

164. See, e.g., Wallace E. Oates \& Robert M. Schwab, Economic Competition Among Jurisdictions: Efficiency Enhancing or Distortion Inducing, 35 J. PUB. EcoN. 333, 351 (1988) (argning that state jurisdictional competition will not result in efficiency enhancement if policy decisions deviate from the will of the public or if there are "conflicts of interest within a heterogeneous community"); Regan, supra note 140 (argning that landfill space is an exportable commodity the purchase of which ought not to be restricted by protectionist legislation). Some putatively Coasean analyses appear to be of two minds on this issue. See, e.g., Butler \& Macey, supra note 54, who recommend Coasean bargaining between local governments (as opposed to individuals), despite their preference for solutions which internalize both costs and benefits within political decision-making units. Butler and Macey acknowledge "the danger that states will use their police power to engage in costexternalization," but would leave the resolution of these problems to the courts. Id. at 61-62. Richard Posner suggests that Coasean bargaining between states will not work. See RICHARD A. PoSNER, ECONOMIC ANALYSIS OF LAW 636 (4th ed. 1992); see also Ingberman, supra note 54, at S-21, (suggesting that Butler and Macey's solution simply recreates the cost-shifting process, this time within the boundaries of the local government, because impacts are concentrated on those closest to the noxious facility, a majority of voters within that boundary will suffer less than average impacts); Mark Tushnet, Rethinking the Dormant Commerce Clause, 1979 W1s. L. REv. 125, 146 (1979) (advocating private law solutions, but with proper "damage rules and user charges [that] force each enterprise to bear the external costs it imposes").

165. A recent Congressional Research Service report lists several factors promoting the interstate transfer of waste:

Interstate shipınent of waste has beconıe more common in recent years. The reasons include local shortages of disposal capacity, particularly in the Northeast and on the West Coast; a national trend toward larger regional disposal facilities; regional differences in the cost of disposal.

McCarthy, supra note 84. The Congressional Research Service has also reported data on the active interstate market in municipal solid waste, mcluding lists of net importers and net exporters. See James E. McCarthy, Interstate Shipment of Municipal Solid Waste: 1998 Update, Congressional Research Service (Aug. 6, 1998) (visited July 12, 1999) <http://www.cnie.org/nle/waste-7.html >. Citing another Congressional Research Service Report, Kirsten Engel reports variations in waste disposal costs ranging from as low as $\$ 11 /$ ton to as high as $\$ 100 /$ ton (1993 data). See Engel, supra note 140 , at 1490 . 
higher. ${ }^{166}$ Further, say the defenders, the fact that lower land values and incoine levels influence disposal costs implies no inequity. To the contrary, to refuse private citizens the right to be coinpensated (and to define their own compensation rates) for accepting waste for disposal is a greater inequity. ${ }^{167}$ Finally, to the extent that lower external costs are a function of lower regulatory standards, this may reflect a conscious decision on the part of the citizens of the state to accept those social costs in return for the compensation (economic activity) that comes with it, ${ }^{168}$ whereas costshifting regulations involve no such balancing. Thus, the Coasean rejoinder views state and local government restrictions on externalities as distortions of the market, and condemns those regulations as barriers to efficiency. ${ }^{169}$ Defenders of the Coasean view argue that these are the very kinds of barriers that courts ought to strike down and that the founding fathers sought to preclude when they erected the constitutional foundations of modern preeinption doctrine.

In this way, commentators have explored the normative consequences of a preemption jurisprudence that encourages a national market in externalities. Commentators have paid less attention to the question of how we arrived at this point. While preemption doctrine is the product of years of controversial and conflicting judicial decisions, no one has attempted to explain what motivates judicial outcomes in preenption disputes. At least, no one has attempted a systematic analysis of the kind we undertake here. Our hope is to help illuminate the normative debate over the future direction of preemption doctrine by trying to make sense of this seemingly indecipherable case law. We turn to that task in Part III.

166. Engel reports that waste-importing states have $\mathbf{1 7 3 . 2 5}$ fewer people per square mile than waste exporting states. See Engel, supra note 140, at 1562. Though not a defender of current doctrine, she acknowledges this argument:

Consumer waste disposal costs will reflect real estate and siting costs, both of which should be lower in a more sparsely-populated state due to the comparative lack of competition for landfill sites. Population density could also affect the magnitude of the public and private health costs resulting from landfill disposal simply hecause fewer persons will be harmed in the event of environmental contamination.

Id. at 1509-10 (note omitted).

167. See Richard L. Revesz, The Race to the Bottom and Federal Environmental Regulation: A Response to Critics, 82 MinN. L. REv. 535, 536-37 (1997):

[O]ur country is large and diverse; it is therefore likely that different regions have different preferences for environmental protection. Environmental protection addresses an important resource-allocation question: as a society we can generally purchase additional environmental protection at some price, paid in the currency of jobs, wages, shareholders' profits, tax revenues, and economic growth.

168. See id.

169. Hand in hand with this argument goes the idea that out-of-state interests are not represented in state (or local) political processes, and so make easy targets. See Regan, supra note 140, at 1161; Tushnet, supra note 164, at 131-33. 
III

\section{Analysis: Explaining Modern Preemption Decisions}

In an attempt to understand preemption jurisprudence, we consider it as an organic whole, rather than as a series of individual cases divided into two groups. Central to this task is an examination of the underlying forces that determine how these cases are decided. Of course, that is no small undertaking, given the complexity of these issues and of judicial decision making $\mathrm{m}$ general. We will approach the analysis as follows. In Part III.A, we will discuss some threshold issues, including a potential bias toward decisions preempting local regulations in our sample, and a proposed taxonomy for considering the myriad variables that may influence judges' decisions in preemption cases. In Part III.B, we will examine those variables individually, looking for observable patterns in the relationship of each to judges' decisions, as a prelude to our multivariate analysis. Our focus in Part III.B will be on lower federal court judges' decisions, ${ }^{170}$ in part because they are more numerous, but also because the bulk of the conflicts we have outlimed occur at that level. In Part III.C, we will perform our multivariate statistical analysis of these decisions. Due to the large number of variables at work here, it is difficult to isolate the effects of each using traditional analytical techniques; the statistical analysis offers a way to identify the individual effects of each variable on decision outcomes while controlling for the effects of others.

\section{A. Some Threshold Issues}

\section{Potential Bias Toward Preemption}

Before we examine the menu of potential explanatory variables at work here, we need to address an issue to which we have already alluded: the strong predominance of decisions preempting state or local regulations (see Table 1 , page 1161$)^{171}$ in our sample. At first glance, this might seem surprising. ${ }^{172}$ One might expect to see just the opposite, given

170. Our unit of observation here will be the decisions of individual judges, not the decisions of courts. The reasons for this distinction will become apparent as we describe the analysis further. Generally speaking, however, we focus on the decisions of individual judges because that is the phenoinenon we seek to explain, and because the explanatory variables that we will examine vary by the judge. If we were to focus on the decisions of courts rather than individual judges (some of which are decisions by three-judge panels in our sample of cases), we would lose the ability to examine those variables.

171. The same trend is also evident in the Supreme Court decisions, where forty-nine of the seventy-two votes in preemption cases have favored preempting the state or local law. (See Appendix $B$, infra, for a list of the eight cases involved.) Interestingly, in the Supreme Court votes, the trend toward preemption is more pronounced among Commerce Clause cases than Supremacy Clause cases, just the opposite of what Table 1, page 1161, reflects in the lower court decisions.

172. As we have noted, it has provoked condemnation from soine commentators. See supra Part II.C; see also Erin A. Walter, Note, The Supreme Court Goes Dormant When Desperate Times Call for 
growing public support for state and local police power regulation, and a largely conservative (or at least, Republican, and presumably pro-states' rights) federal jndiciary. ${ }^{173}$ While our analysis of explanatory variables will address some of these issues, there may be another, simpler explanation for the predominance of preemption outcomes in these cases. That explanation is based upon the unusual motives of the litigants in these cases. Most rational parties to litigation are willing to litigate only those issues for which the estimated probability of success is high, or high enough to make worthwhile the cost of litigation. That is, we commonly conceive of the litigation decision as one that involves a comparison between the expected costs of litigation, $E(C),{ }^{174}$ and the expected value of the outcome of the litigation, $E(O)$, which can be snmmarized as follows:

$$
E(O)=\text { probability of victory } x \text { value of victory } y^{175}
$$

For the vast majority of litigation disputes, the value of victory (like litigation costs) can be expressed in dollar terms for both parties. Where both parties to a dispute view the decision to litigate in these terms, we would expect to see a predominance of "close cases" among those that are litigated to a conclusion. In other words, if $E(O)-E(C)$ is negative or sufficiently close to zero for one party to the dispute, that party should seek to settle the case. ${ }^{176}$ Hence, barring large disparities in the estimates of $E(O)$ and $E(C)$ between the parties, only close cases shonld be litigated.

In regnlatory preemption disputes, however, the value of victory is often measured in terms other than dollars, at least by one party to the dispute. In preemption cases, the real parties at interest are often a private sector actor seeking to maintain or introduce some sort of perceived hazard into a cominunity, on the one hand, and a state or local government (and its constituents) seeking to exclude the hazard, on the other. ${ }^{177}$ While the private sector actor will typically make the decision to litigate according to the calculation described above, the public sector actor may calculate the value of victory differently. That is, for elected politicians, there may be a

Desperate Measures: Looking to the European Union for a Lesson in Environmental Protection, 65 FORDHAM L. REv. 1161 (1996).

173. For a discussion of the distribution of outcomes by party of the deciding judge, see infra Part III.B.1.

174. Another way to conceive of $E(C)$ is that it represents the transaction costs of litigating.

175. Here, $E(O)$ is actually an estimate of the likely net outcome, and would mclude estimates of the value of winning (that is, a dollar judgment in your favor or dollar benefits of a victory) and the (negative) value of losing (that is, a dollar judgment against you or dollar costs of losing). Thus, a nore completc expression might be: where $p$ is the probability of victory.

$$
E(O)=[p(\text { value of winning })-(1-p)(\text { value of losing })]
$$

176. Of course, that would mean we ought to see a roughly equal distribution of outcomes in our sample, all else being equal.

177. This is evident from our summary of the cases in Section II, supra, or from a review of the table of cases in our sample, in Appendix B, infra. 
great deal of symbolic or political "value" in pursuing a losing case. ${ }^{178}$ In other words, it is rational for public sector actors who are responsive to public pressure to litigate even when the probability of victory is low, because they receive political benefits for fighting the losing battle. This phenomenon explains the almost Sisyphean persistence with which some state and local governments pursue regulation in the face of a preeinption threat. It may also create a built-in bias toward preemption outcoines in these cases, one that persists apart from any of the other explanatory variables we will consider. ${ }^{179}$ Hence we note this here, as a preface to our consideration of those explanatory variables. ${ }^{180}$

Table I: Distribution of Outcomes in Our Sample of Decisions (Lower Federal Court Decisions) ${ }^{a}$

\begin{tabular}{|c|c|c|}
\hline . & $\begin{array}{c}\text { No. OF Decisions } \\
\text { PreEMPTING Local LAW }\end{array}$ & $\begin{array}{c}\text { No. OF DECISIONS } \\
\text { UpHOLDING LOCAL LAW }\end{array}$ \\
\hline $\begin{array}{c}\text { Commerce Clause } \\
\text { Cases }\end{array}$ & 28 & 22 \\
\hline $\begin{array}{c}\text { Supremacy Clause } \\
\text { CASES }\end{array}$ & 74 & 42 \\
\hline
\end{tabular}

a Each judge's vote constitutes a separate decision.

\section{Proposed Taxonomy of Explanatory Variables}

How, then, can we try to understand and explain this preemption jurisprudence? One straightforward approach would be to examine the

178. This is especially true where the prospectively preempted law is a local government ordinance, simce the pubhic sector litigants are usually directly elected politicians, such as the members of a town board. Where a state is the public-sector party at interest, litigation decisions are usually made by either unelected agency bureaucrats or the elected state attorney general. Where unelected bureaucrats are subject to this same set of incentives only indirectly, we might expect that indirect effect to be a weaker one.

179. This kind of bias is common. In statistical parlance, it is often referred to as a "censored sample" or "truncated sample" problem, or a problem of "selection on the dependent variable." There are a variety of statistical techniques that can be used to adjust for these problems, depending on the circumstances. See, e.g., William H. Greene, Econometric ANALYsis 715-50 (1990); G.S. Maddala, Limited-Dependent and Qualitative Variables in Econometrics 149-96 (1983). Because most correction techniques require information about the "missing" or unseen cases, this bias often goes uncorrected because that information is often unavailable, as is the case in this instance. See MADDALA, supra, at 149-96.

180. See infra Appendix B for a discussion of a related data censoriug issue: the argument that the settlement process filters out all but the random variation in these data, leaving no explainable variation to analyze. 
opinions thenuselves to see what factors the judges credit for their decisions. Certainly there is no shortage of evidence to support this approach, and traditional legal scholarship often relies on a critical examination of opinions to discern applicable decision rules. We believe, however, that that kind of analysis is insufficient here, for at least two reasons. First, the previously mentioned ${ }^{181}$ and unusually sharp ideological and political conflicts preemption cases pose for judges make the task of sorting out decision rules inherently complex. These ideological conflicts are multidimensional, and include (1) constitutional principles of federalisn, (2) statutory interpretation problenus (in the case of Supremacy Clause cases), (3) sonietinies intense political pressures, and (4) judges' political or policy preferences and attitudes toward regulation generally. Second, because judicial norms proscribe citing political pressures or policy preferences as the basis for judicial decisions, all (or nearly all) preeniption opinions are cloaked in the language of the first two sets of decision rules, regardless of the actual basis of the decision. ${ }^{182}$

Therefore, while examining the judicial opinions is a good first step, it is especially important to look skeptically at the putative bases for preeniption decisions. Consider Table 2, page 1163, which proposes a classification of the variables that may influence preemption decisions, ${ }^{183}$ and

181. See supra Introduction.

182. This is a polite way of saying that these cases offer ample opportunity for what Walter Murphy called "policy-oriented justices" to misrepresent their motives and reasoning. See WALTER F. MuRPhy, ElEments of Judicial STrategy 4 (1964). Of coursc, this does not necessarily imply an intent to dissemble on the part of the judge, because policy preferences may influence judges in unconscious ways.

183. Of course, the larger issue of what motivates judges generally is an especially thorny one, and is addressed by an enormous and complex literature in law and the social sciences. The taxonomy in Table 2, page 1163, implies that it is possible, and possibly fruitful, to look beyond judges stated reasons to discern their "true" decision rules. This is, of course, a staple of behavioral social scicnce, and many social scientists who study the courts subscribe to the view that judges are primarily "policy maximizers" whose decisions reflect a desire to achieve particular policy results. Two judicial politics scholars recently put it this way:

A half century of empirical scholarship has now firmly established that the ideological values and policy preferences of Supreme Court justices have a profound impact on their deeisions in many cases.

Donald R. Songer \& Stefanie A. Lindquist, Not the Whole Story: The Impact of Justices' Values on Supreme Court Decision Making, 40 AM. J. PoL. Sc1. 1049 (1996). This characterization of Supreme Court justices' motives has been extended to other judges as well, by political scientists and legal scholars alike. For a good summary of the evolution of the debate within political science, see Richard A. Brisbin, Jr., Slaying the Dragon: Segal, Spaeth and the Function of Law in Supreme Court Decision Making, 40 AM. J. PoL. Sc1. 1004, 1004-5 (1996). Many legal scholars share this view as well. See, e.g., Frank B. Cross \& Emerson H. Tiller, Judicial Partisanship and Obedience to Legal Doctrine: Whistleblowing on the Federal Courts of Appeals, 107 YALE L.J. 2155, 2156 (1998) (much "scholarship simply assumes the sincere application of legal doctrine without considering the possibility that it may at times be nothing more than a convenient rationalization for political decisionmaking"); Richard J. Pierce, Jr., Two Problems in Administrative Law: Political Polarity on the District of Columbia Circuit and Judicial Deterrence of Agency Rulemaking, 1988 DuKE L.J. 300 (ascribing judicial decisions primarily to policy preferences of judges). Frank Cross uses the term "the 
divides those explanatory variables along two dimensions: internal vs. external factors, and explicit vs. implicit factors. ${ }^{184}$ "Internal" forces are those that come from within the judge-motives that tend to impel the judge toward a particular goal or conclusion-including the judge's ideological beliefs. ${ }^{185}$ "External" forces are circumstances of the case or its environment that tend to compel the judge to reach a particular result, including both political and strategic considerations. "Explicit" factors are

Table 2: Potential Variables Explaining Preemption Decisions

$\begin{array}{ccc}\begin{array}{c}\text { INTERNAL } \\ \text { (IDEOLOGICAL) }\end{array} & \begin{array}{c}\text { EXTERNAL } \\ \text { (CIRCUMSTANTIAL) }\end{array} \\ \text { EXPLICIT (PUTATIVE) } & \begin{array}{c}\text { Philosophy of federalism } \\ \text { Philosophy of regulation }\end{array} & \begin{array}{c}\text { What the law "requires" } \\ \text { What Congress or the } \\ \text { Framers intended }\end{array} \\ \text { IMPLICIT } & \begin{array}{c}\text { Policy goals } \\ \text { (HIDDEN OR }\end{array} & \begin{array}{c}\text { Strategic considerations } \\ \text { (such as probability of } \\ \text { UNCONSCIOUS) }\end{array} \\ \text { legislative override) }\end{array}$

new legal realists" to describe this view. Frank B. Cross, Political Science and the New Legal Realism: A Case of Unfortunate Interdisciplinary Ignorance, 92 Nw. U. L. REv. 251 (1997) According to this view, judges only invoke higher principles (or invoke them selectively) when necessary to achieve the desired end result.

This view is contrasted with the traditional legal model, which emphasizes interpretive techniques and legal reasoning as taught in law schools, and reference to higher principles (for example, stare decisis, constitutional doctrines, etc.) as key decision criteria. For the classic explication of this view, see, for example, Benjamin N. Cardozo, The Nature of the Judicial Process 112 (1921) ("My analysis of the judicial process comes then to this, and little more: logic, and history, and custom, and utility, and the accepted standards of right conduct, are the forces which singly or in combination shape the progress of the law."). For a more recent and circumspect version of the traditional view, arguing that judges are constrained by these higher duties, see James L. Gibson, Decision Making in Appellate Courts, in The American Courts: A Critical Assessment (John B. Gates \& Charles A. Johnson eds., 1991). For an interesting comparison of the two models, see Cross, supra.

We take no position in this larger debate. We simply note that this is an open question, and hope that this analysis will add to the body of empirical work that the combatants bring to that argument.

184. We explam the contents of the cells in Parts II.B.1 and 2, infra.

185. This category mirrors the kinds of "attitudinal" variables on which judicial politics scholars focus. Perhaps the most well-known of these approaches is that taken by political scientists Jeffrey A. Segal and Harold J. Spaeth. See Jefrrey A. Segal \& Harold J. Spaeth, The Supreme Court and THE ATTITUDINAL MODEL (1993). 
those judges tend to cite in their opiuions; "implicit" factors are those which are generally not cited. ${ }^{186}$ Each of the four types of variables represented by Table 2 , page 1163 , are potentially at work in modern preemption jurisprudence. Using this taxonomy, we will now examine the distribution of these variables over the entire sample of cases.

\section{B. Explanatory Variables}

\section{Internal/deological Forces}

Among the internal variables potentially at work in these cases, we have already alluded to the most prominent-the judge's philosophy of federalism and the judge's regulatory policy preferences. The former vanable is usually explicit, and refers to the judge's predispositions as to the proper location of the boundary between federal and state or local regulatory authority. ${ }^{187}$ The latter variable, on the other hand, is almost always implicit, and refers to the judges' policy preferences concerming the regulation at issue. If a judge is influenced by her preference for a particular outcome im these policy disputes, that preference may influence her decision in preemption disputes, all else being equal. We have also alluded to a third internal, ideological variable, one that is related to but not coterminous with judges' policy preferences and that may be either explicit or implicit. We have described this variable as the "Coase vs. Pigou" debate. In Table 2, page 1163, we call this variable the judge's "philosophy of regulation" for lack of a nore descriptive term.

Table 3, page 1165, summarizes these three ideological dimensions. The problem for analysts of these decisions is that while these ideas are analytically distinct, it is difficult to evaluate them separately because we have no a priori measure of judges' predispositions under any of the three. ${ }^{188}$ We do know each judge's political affiliation, however, and we

186. This dimension tracks, roughly, the differences between the traditional legal model of decision making and social science models like Segal and Spaeth's attitudinal model. See supra note 195. That is, social scientists tend to credit the importance of factors we describe here as implicit, while the traditional legal model tends to credit the importance of factors we describe here as explicit.

187. Recall that Anti-Federalists feared that Federalist judges would be quicker to precmpt state and local laws because of their preference for a strong national government; it may be that modern-day Federalists and Anti-Federalists bring corresponding predispositions to modern preemption cases. See supra note 29.

188. There are indices of judicial "ideology" for members of the Supreme Court. For an example of an analysis employing such scores, see Joyce Ann Baugh et al., Justice Ruth Bader Ginsburg: A Preliminary Assessment, 26 U. ToL. L. REv. 1 (1994). These have been calculated by scholars based upon individual justiees' decision records, and typically assign eacl justice a position on a continuum of liberalism/conservatism. These indices are therefore similar to scores assigned to members of Congress by various interest groups. See, e.g., the Americans for Democratic Action ("ADA") voting scores, at <http://adaction.org>, the American Conservative Union's ("ACU") votiug scores, at $<\mathrm{http} / / / w w w . c o n s e r v a t i v e . o r g>$, and the League of Conservation Voters ("LCV") voting scores, at <http://www.lcv.org>. Like the ADA and ACU congrcssional voting scores, these judicial scores are 
might expect party to be related to ideology in predictable ways, as Table 3 , page 1165 , indicates. ${ }^{189}$ While that is true, party affiliation is a poor proxy here, in part because it must serve as a simultaneous proxy for more than one variable. For example, if party affiliation must serve as a proxy for judges' philosophy of federalism and their policy goals, two variables that are in tension with one another, we cannot measure those separate effects with a single piece of information. ${ }^{190}$ Conversely, it appears from Table 3, page 1165, that philosophy of regulation (the Pigovian vs. Coasean dimension) is indistinguishable from the policy goals variable, because party affiliation varies identically with both. That is, for Republicans, both dimensions tend toward preempting the local regulation; the converse is true for Democrats.

TABle 3: Hypothesized Relationship of IDEOlogical Variables to Party AFFILIATION

\begin{tabular}{lccc} 
& $\begin{array}{c}\text { PHILOSOPHY OF } \\
\text { FEDERALISM }\end{array}$ & $\begin{array}{c}\text { PHILOSOPHY OF } \\
\text { REGULATION }\end{array}$ & $\begin{array}{c}\text { RELATIVE POLICY } \\
\text { PREFERENCES }\end{array}$ \\
\hline $\begin{array}{l}\text { DEMOCRATIC } \\
\text { APPOINTEES }\end{array}$ & $\begin{array}{c}\text { Favor federal } \\
\text { power }\end{array}$ & $\begin{array}{c}\text { Pigovian (favoring } \\
\text { cost- } \\
\text { internalization) }\end{array}$ & pro-environment \\
$\begin{array}{l}\text { REPUBICAN } \\
\text { APPOINTEES }\end{array}$ & $\begin{array}{c}\text { Favor state or } \\
\text { local power }\end{array}$ & $\begin{array}{c}\text { Coasean (favoring } \\
\text { market solutions) }\end{array}$ & $\begin{array}{c}\text { anti-(or less pro-) } \\
\text { environunt }\end{array}$ \\
\end{tabular}

There are, however, a couple of ways we can try to disentangle these effects. First, we can distinguish the effects of philosophy of regulation from those of policy preferences, despite the fact that both usually point judges in the same direction. This is because there are cases where the two variables point judges in opposite directions. For example, in cases

unidimensional in that they conflate (or do not distinguish between) sub-issues which coinprise judicial "liberalism" or "conservatism." Hence, they do not shed much light on the problein we are attempting to address here.

189. This is commouly assumed to be the case, and it is routine for analysts to treat Democrats as inore pro-environment, more Pigovian, more pro-national power, and less Coasean, than Republicans. For evidence to support these generalizatious, see the ADA and LCV web sites, supra note 188. As explained in Appendix B, infra, we assign judges a party affiliation based on actual party affiliatious (as reported in available biographical dictionaries) or, in the absence of that information, the party of the appointing president.

190. This is especially problematic because in each case in our sample the potentially preempted state or local law would result in more stringent regnlation than the federal standards alone; hence, these two variables operate as perfect complements, making them indistinguishable in a statistical analysis. 
involving local "right-to-know" laws, ${ }^{191}$ the Coasean position favors upholding the local law. This is because right-to-know laws are designed to facilitate privately negotiated Coasean solutions to externality problems. Therefore, for cases involving the possible preemption of state or local right-to-know laws, a decision to preempt the local law is not an expression of the Coasean position (as it is in the usual case). Likewise, there are cases in our sample of lower court decisions (a minority) where the Pigovian position favors preemption. These tend to be cases involving NIMBY-motivated regulations designed purely to externalize costs generated in the local commumity. Thus, this variation between the philosophy of regulation dimension and the policy preferences dimension ${ }^{192}$ should enable us to distingnish the two.

This still leaves us, however, with party affiliation serving as a proxy for two internal variables: judges' philosophy of federalism and judges' policy preferences. In the usual case in which two ideological dimensions vary in opposite directions with party affiliation, they may cancel each other out, producing no visible effect. In such cases, we cannot tell whether the ideological factors are unimportant or are masking each other's effects. On the other hand, if we observe an apparent party effect in these decisions, we can infer that one dimension or the other is driving the result. In other words, because we can inake inferences about the likely predispositions of judges based on party affiliation, we may be able to discern judges' true motives when they "go against type." Thus, if it appears that Democrats are more likely, and Republicans less likely, to preempt state or local regulation, then we can infer that the philosophy of federalism dimension is playing a larger role in judges' decisions than are their policy preferences. ${ }^{193}$ This is because we do not expect Democrats to embrace a states' rights philosophy of federalism, or Republicans to embrace relatively more pro-environment policy preferences. We can make just the opposite inferences if it appears that Republicans are more likely than Democrats to preempt state or local regulations.

By examining the data with these distinctions in mind, we can begin to make educated guesses about judges' true motives. Consider first Table 4 , page 1167, which illustrates the predominance of Republican judges in the federal judiciary, soinething to which we have already alluded. In

191. See supra note 139.

192. For a description of how we coded the Pigovian and Coasean positions in each case, see Appendix B, infra.

193. For example, when an otherwise conservative Justice Rehnquist votes to uphold local government attempts to ban the importation of garbage, and does so in Pigovian terms, we might infer that Rehnquist is motivated by his philosophy of federalism rather than other ideological concerns, since we do not expect conservatives to adhere to a pro-regulation or Pigovian philosophy. See supra note 155. Thus, we can infer that his Pigovian rationale is a kind of bootstrap argument, and sccondary to his more cherished, pro-states rights' values. 
Table 4, page 1167, just under two-thirds of the decisions were made by Republican appointees; of those, just under one-lialf (and almost thirty percent of all decisions) were made by Reagan appointees. ${ }^{194}$ Table 5, page 1168, shows how these different categories of judges-Reagan appointees, Republicans, and Democrats, respectively-resolved the preemption conflicts at issue in our sample. ${ }^{195}$ Table 5, page 1168, provides ample evidence of the sample bias we have noted toward preemption outcomes.

\section{Table 4: Distribution of Decisions by Party and Appointing President (Lower Federal Court Decisions) ${ }^{\mathrm{a}}$}

\begin{tabular}{ccccc} 
& GOP & DEM & $\begin{array}{c}\text { REAGAN } \\
\text { APPOINTES }\end{array}$ & OTHERS \\
\hline $\begin{array}{c}\text { COMMERCE } \\
\text { CLAUSE CASES }\end{array}$ & $30(60 \%)^{\mathrm{b}}$ & $20(40 \%)$ & $19(38 \%)$ & $31(62 \%)$ \\
$\begin{array}{c}\text { SUPREMACY } \\
\text { CLAUSE CASES }\end{array}$ & $73(63 \%)$ & $42(37 \%)$ & $29(25 \%)$ & $87(75 \%)$ \\
& & & \\
\end{tabular}

a Each judge's vote constitutes a separate decision.

${ }^{b}$ Numbers in parentheses are row percentages.

In addition, Table 5 indicates that non-Reagan appointee Republicans appear to be slightly more likely to preempt state or local regulations than either Reagan appointees or Democrats, which seems an odd result because we expect Republicans (and especially Reagan appointees) to hold relatively Coasean and anti-environment views. However, the difference appears to be a small one, and there does not appear to be any significant difference in the behavior of judges based on either party affiliation or appointing president based on these general data. ${ }^{196}$ Of course, we cannot tell

194. We note this because of the Reagan Administration's well-known commitment to states' rights and because it is also well understood that appointee ideology played a stronger role in Reagan administration appointments than those of other presidents. For a discussion of this issue, see William E. Kovacic, The Reagan Judiciary and Environmental Policy: The Impact of Appointments to the Federal Courts of Appeals, 18 B.C. ENVTL. AFF. L. REv. 669 (1991). The effect is even more pronounced at the Supreme Court level. Of the seventy-two votes cast by Supreme Court judges in onr sample, $86 \%$ were decided by Republican appointees. Of those, almost half were cast by appointees of Ronald Reagan.

195. Note that in Table 5, page 1168, the numbers in parentheses represent column percentages, not row percentages as in previous tables.

196. Among Supreme Court decisions there are some interesting differences among the three groups of justices, though we must be careful about drawing inferences from the data given the small number of decisions involved. Democratic appointees appear more likely to preempt local regulations than their Republican counterparts (and do so $90 \%$ of the time), though the number of Democratic appointee decisions is very small. Among Republican appointees, Reagan appointees are more likely to 
at this first glance whether the ideological variables we associate with party affiliation and appointing president are ineffective or simply canceling each other out; the multivariate analysis may reveal ideological effects that could be hidden in these data. Meanwhile, we can try to examine the effects of judges' philosophies of regulation on judges' decisions.

\section{Table 5: Outcomes by Party and Reagan Appointee Status (Lower Federal Court Decisions) ${ }^{a}$}

\begin{tabular}{|c|c|c|c|}
\hline & $\begin{array}{l}\text { REAGAN } \\
\text { APPOINTEES }\end{array}$ & OTHER GOP & DEM \\
\hline $\begin{array}{c}\text { DECISIONS } \\
\text { PREEMPTING } \\
\text { LOCAL LAW }\end{array}$ & $30(61 \%)^{b}$ & $37(66 \%)$ & $38(60 \%)$ \\
\hline $\begin{array}{c}\text { DeCISIONS Not } \\
\text { PREEMPTING } \\
\text { LOCAL LAW }\end{array}$ & $19(39 \%)$ & $19(34 \%)$ & $25(40 \%)$ \\
\hline
\end{tabular}

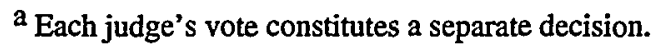

b Numbers in parentheses are column percentages.

Table 6, page 1169, examines the question of whether Reagan appointees or Republicans were indeed more likely than other judges to follow the Coasean position in these disputes, as we hypothesized. In Table 6, the numbers in the cells show the distribution of judges' decisions based upon whether they were consistent with the Coasean philosophy of regulation. ${ }^{197}$ All three categories of judges tend to follow the Coasean prescription most of the time. ${ }^{198}$ This is not surprising, however, since in the usual case the Coasean prescription will be to preempt the local regulation to allow a market-driven, private solution to the problem. ${ }^{199}$

preempt local regulations than other Republicans ( $73 \%$ to $63 \%$, respectively), which is a counterintuitive result on the philosophy of federalism dimension, but consistent with the view that Reagan appointees have more anti-environmeut policy preferences and more Coasean philosophies of regulation.

197. Since the Coasean view prefers private solutions to governmental solutions generally, this view suggests that most (but not all) state and local regulation should he preempted. See Appcndix B, infra, for a full description of the coding of this variable.

198. This same trend is present in the Supreme Court data. However, Republican appointees on the Court other than Reagan appointees were the most dedicated Coaseans, adhering to the Coasean point of view $89 \%$ of the time. Oddly, Reagan appointees were no more likely than Democrats to follow the Coasean prescription: Both followed it about $70 \%$ of the time.

199. Another possible inference for Democratic appointees is that since we do not expect Democrats to hold a Coasean regulatory philosophy, we might infer that their philosophy of federalism explains this result. 
Table 6: Do Judges Follow Coasean Prescription? Decisionsa Following. Coasean Prescription By Party and Reagan Appointee Status (Lower Federal CoUrt Decisions)

\begin{tabular}{|c|c|c|c|}
\hline & $\begin{array}{c}\text { REAGAN } \\
\text { APPOINTEES }\end{array}$ & OTHER GOP & DEM \\
\hline $\begin{array}{l}\text { DeCisions Following } \\
\text { CoASEAN Position }\end{array}$ & $29(64 \%)^{b}$ & $27(51 \%)$ & $35(58 \%)$ \\
\hline $\begin{array}{c}\text { DeCisions Not } \\
\text { Following CoAsEAN } \\
\text { Posirion }\end{array}$ & $16(36 \%)$ & $26(49 \%)$ & $25(42 \%)$ \\
\hline
\end{tabular}

More interesting, however, are the differences we observe among the categories of judges in Table 6, particularly the comparison of Reagan appointees to other Republicans. The differences between these two groups appear slightly more pronounced here than in Table 5, page 1168. These data suggest that Reagan appointees may be more Coasean than other judges in the lower federal courts. That is, Reagan appointees' decisions may be driven by their preference for privately negotiated solutions more so than those of their Republican colleagues, who appear less likely than even Democratic appointees to follow the Coasean prescription in these disputes. ${ }^{200}$ Since the Coasean position does not always favor preemption, this result implies that the decisions of non-Reagan appointee Republicans are likely driven by considerations other than their philosophy of regulation.

Table 7 addresses the analogous issue of whether any of these groups of judges seein to be guided by a Pigovian philosophy of regulation. In Table 7, the numbers in the cells reflect the percentage of judges' decisions that were consistent with the Pigovian philosophy of regulation. While neither party's appointees appear to be generally Pigovian in their philosophies of regulation, ${ }^{201}$ Deinocrats do appear to follow the Pigovian prescription inore often than Republicans. ${ }^{202}$ This is consistent with our

200. This counterintuitive result could be a function of other differences between these categories of judges; if so, the multivariate analysis may reveal that fact.

201. Once again, since the Pigovian prescription is often (though not always) to uphold the state or local regulation, the bias toward preeinption outcoines in our sainple may be partly responsible for this overall trend.

202. This saine trend was not reflected in the Supreme Court data, where Republicans followed the Pigovian prescription more often than Democrats (34\% to $10 \%$ of the time, respectively). 
expectations, because Democrats are associated with a more Pigovian view of regulation -one that looks favorably on cost-internalizing regulation. ${ }^{203}$

Table 7: Do Judges Follow Pigovian Prescription? Decisions ${ }^{a}$ Following Pigovian Prescription By Party

\begin{tabular}{|c|c|c|}
\hline & DEMOCRATS & GOP \\
\hline $\begin{array}{l}\text { Decisions Foliowing } \\
\text { Pigovian Position }\end{array}$ & $23(42 \%)^{b}$ & $30(36 \%)$ \\
\hline $\begin{array}{c}\text { DeCISIONS Not } \\
\text { FoLLOWING PIGOVIAN } \\
\text { PoSITION }\end{array}$ & $32(58 \%)$ & $54(64 \%)$ \\
\hline
\end{tabular}

a Each judge's vote constitutes a separate decision.

$\mathrm{b}$ Numbers in parentheses are column percentages.

While these results confirm our view of Democrats' and Reagan appointees' (if not Republicans') philosophies of regulation, we need to cut the data more finely in order to distinguish true Coaseans and Pigovians from the fair-weather variety who embrace these philosophies only when they are consistent with their policy goals. That is, would Democrats be more likely than Republicans to embrace the Pigovian prescription if that prescription conflicts with their (relatively pro-environment) policy goals? Likewise, would Republicans be more likely than Democrats to follow the Coasean path if that path diverges from their (relatively less proenvironment) policy goals? Table 8, page 1171 , addresses these questions by isolating decisions in which the judges' assumed philosophy of regulation conflicts with their assumed policy preferences. For Democrats, there will be cases in which the Pigovian prescription calls for preempting the state or local regulation; for Republicans, these will be cases in which the Coasean prescription calls for upholding the state or local regulation.

The key cells, then, are the upper right hand cell and the middle and lower left hand cells. According to Table 8, neither party's appointees seem to be particularly dedicated to their respective philosophies of regulation when push comes to shove. However, we do see some interesting behavioral differences in these data. In particular, the differences between Reagan appointees and other Republicans grow even more pronounced here. While Republicans are less likely than Democrats to adhere to the

203. However, the fact that the Pigovian prescription tends to coincide with Democrats' poliey preferences means that we should be cautious about drawing any such inference; once again, however, the multivariate analysis will enable us to separate out these effects. 
Coasean point of view when it calls for upholding the state or local regulation at issue, that difference is accounted for solely by non-Reagan appointee Republicans. That is, non-Reagan appointee Republicans appear less predisposed to Coasean solutions than either Democrats or Reagan appointees. Turning to the right-hand column in Table 8, the Deinocrats' relatively inore Pigovian behavior disappears in situations when the Pigovian position is to preempt the local environmental, health or safety regulation. In such cases, Democrats are no more likely than Republicans to follow that prescription. ${ }^{204}$ It may be that the results in Table 7, page 1170 , were an artifact of Democrats' policy preferences rather than their Pigovianism.

Table 8: Decisions a Following the Coasean and Pigovian Prescriptions in Selected Situations

\begin{tabular}{|c|c|c|}
\hline & $\begin{array}{c}\text { When COASEAN } \\
\text { Prescription Is to UPHold } \\
\text { REgUlation }\end{array}$ & $\begin{array}{c}\text { When Pigovian } \\
\text { Prescription Is to } \\
\text { Preempt Regulation }\end{array}$ \\
\hline DEMOCRATS & $56 \%$ & $53 \%$ \\
\hline $\begin{array}{c}\text { ALL } \\
\text { REPUBLICANS }\end{array}$ & 34 & $55 \%$ \\
\hline $\begin{array}{c}\text { REAGAN } \\
\text { APPOINTEES ONLY }\end{array}$ & $\therefore \quad:^{53 \%} \quad:$ & $50 \%$ \\
\hline ALL JUDGES & $44 \%$ & $55 \%$ \\
\hline
\end{tabular}

a Each judge's vote constitutes a separate decision.

Thus, this first-cut examination of ideological variables in these decisions reveals soine patterns, only soine of which conforin to our expectations. The bivariate analyses indicate that there are significant differences in the behavior of our two categories of Republicans, with nonReagan appointee Republicans appearing both more likely to preempt state or local regulation and less Coasean in their philosophy of regulation. We might infer, therefore, that non-Reagan appointee Republicans are guided by their policy preferences in these cases, since we would not expect Republicans to embrace a nationalist philosophy of regulation. For their part, Democrats' behaviors seem unrelated to their philosophy of regulation. But

204. We performed no analogous analysis of the Supreme Court decisions because of the relative scarcity of cases posing these two situations in that sample. 
it may be that the multivariate analysis will shed some additional light on the role of internal and ideological variables in these decisions. Meanwhile, we turn to our examination of external variables.

\section{External/Circumstantial Forces}

Of course, ideology is but one of many variables bearing on judicial decisions. There are many potential external variables that may influence judges' decisions as well. These include characteristics of the individual case as well as political and strategic considerations. Returning to the taxonomy in Table 2, page 1163, we have divided the umiverse of these external variables into the usually explicit and the usually implicit. Political and strategic considerations tend to fit within the latter category, since traditional norms encourage judges to ignore such concerns; those same norms are more tolerant of decisions guided by the "facts of the case," and so characteristics of the case tend to fit within the former category. Guided by our understanding of the case law, the acadermic literature on judicial decision making, and the limits of available information, we have focused on five external variables for consideration here. ${ }^{205}$

\section{a. Case Type}

We have already examined this first external variable, ${ }^{206}$ which refers to the constitutional provision under which the case arises. Table 4, page 1167, reflects a predominance of preemption outcomes in both Cominerce Clause cases and Supremacy Clause cases, though the disparity is more pronounced among the Supremacy Clause cases. Our primary reason for including this variable in the multivariate analysis is to control for any systematic differences that may exist between these two categories of decisions.

We may ask, however, why federal judges appear to be more likely to preempt state or local regulations under the Supremacy Clause than the Cominerce Clause. One reason might be "deference to Congress." That is, in the Supremacy Clause cases the courts are interpreting congressional mtent. Fimding such intent im the words of Congress might fortify a judge who is predisposed to preempt the state or local regulation. Stated differently, it might be easier, or more comfortable, for a judge to rest a decision to preempt on statutory language rather than on her own interpretation of

205. In earlier versions of this analysis, we examined a variety of other external variables. See infra notes 207 and 219 . The decision to include or exclude a variable from the analysis was made based upon a balance of two factors: its performance as a predictor of these decisions (in either the bivariate or the multivariate analysis), and the need to include the variable in the multivariate analysis as a control for omitted variables. See the discussion of this issue in Appendix B, infra.

206. See supra p. 1161 tbl.1 and accompanying text. We discussed this variable there as part of our introduction to the data set. However, according to our taxonomy, it is propcrly listed here, as an external variable. 
the Commerce Clause. In this way, Supremacy Clause cases allow judges to credit the decision to another authority-Congress. Commerce Clause cases offer no such institutional ally, ${ }^{207}$ all of which suggests that we must account for the various ways deference to Congress may exert effects in these cases.

\section{b. Deference to Congress}

In order to construct a measure of deference to Congress, we need to first define the idea inore precisely. Of course, in preeinption cases courts often defer to Congress, or at least claim they are doing so. This idea subsumes several distinct phenomena. First, courts explicitly defer to Congress in their interpretations of congressional intent in Supremacy Clause cases. In this sense, courts defer to the enacting Congress, or the Congress that passed the federal legislation at issue. Such deference is implicit in Commerce Clause cases as well, where courts defer to Congress's primary (though dormant) right to control interstate commerce.

A second way courts defer to Congress is by taking account of how the current Congress might react to their decisions. ${ }^{208}$ If judges wish to avoid being overruled by Congress, or believe that an unpopular decision will be overruled, that belief may sway the judge's decision. This second form of deference to Congress is almost always implicit, simce such considerations violate judicial norms. Indeed, judicial norms encourage nondeferential reactions to the current Congress, as exeinplified when a judge invites Congress to override her decision. ${ }^{209}$

207. In earlier versions of this analysis we examined whether outcomes in Supremacy Clause cases differed depending on the tendency of courts to characterize the applicable federal statutory preemption clause as a "savings clause" or an "express preemption clause." That variable proved not very helpful in our multivariate analysis. See David B. Spence, Intcr-governmental Conflict in Environmental Law: Federal Preemption of State and Local Environmental Regulation, Address Before the Association for Public Policy Analysis and Management (Nov. 2-4, 1995). We decided not to include this variable because it appears that these differing characterizations of preemption provisions carry little meaning. Rather, they appear to be post hoc rationalizations designed to buttress the ultimate decision ontcome. In addition, there appears to be no discernible difference between provisions that courts typically characterize as express preemption provisions and those they characterize as savings clauses. For example, OSHA's preemption provision is usually characterized as an express preemption provision (by negative imphication). See Ferdinand S. Tinio, Annotation, PreEmptive Effect of Occupational Safety and Health Act of 1970 (29 U.S.C.S. \$\$ 651-678) and Standards Issued Thereunder, 88 A.L.R. FED. 833 (1988). Yet, it reads very much like the RCRA savings clause: both are structured as clauses ensuring the continumg right of states to regulate in certain ways. See discussion supra Part II.B.

208. See William N. Eskridge, Jr., Post-Enactment Legislative Signals, 57 L. \& ContemP. Probs. 75 (1994); Edward P. Schwartz et al., A Positive Theory of Legislative Intent, 57 L. \& ConTEMP. PRoBs. 51 (1994).

209. See Pablo T. Spiller \& Rafael Gely, Congressional Control or Judicial Independence: The Determinants of U.S. Supreme Court Labor-Relations Decisions, 1949-1988, 23 RAND J. ECoN. 463 (1992); Pablo T. Spiller \& Emerson H. Tiller, Invitations to Override: Congressional Reversals of Supreme Court Decisions, 16 INT'L REv. L. \& Econ. 503 (1996). We have noted evidence of this kind of invitation to congressional action in Commerce Clause jurisprudence. See supra Part II.A. 
In addition, while these two types of deference to Congress are analytically distinct, they are related in practice. It is not uncommon for judges to give less deference to the enacting Congress as that Congress grows more remote in time. In other words, judges may not always be faithful to congressional desires that seem antiquated or anachronistic. To the contrary, judges sometimes interpret statutes in light of new facts, reasoning that to do so is to do what the enacting Congress would have done under the circumstances. ${ }^{210}$ This kind of reasoning is difficult to distinguish from the idea that judges may feel less constrained by the wishes of the enacting Congress when that Congress is no longer able to override the judge's decision. $^{211}$

The former dynamic is an issue only in Supremacy Clause decisions which, as we have seen, have been overwhelmingly weighted in favor of preempting state or local regulation (see Table 1, page 1161). As we have noted, ${ }^{212}$ the federal statutes at issue in these cases are all more than twenty years old, and were enacted at a time when strong federal regulatory authority was thought to be necessary to prevent a race to the bottom by the states. This philosophical ancestry may explain the predominance of preemption outcomes in these cases, as judges interpret these statutes in light of their history. If judges feel less deference to the enacting Congresses over time, we might expect to see the number of decisions upholding state or local regulations increasing as the enacting Congresses grow more remote in time. In fact, there is some circumstantial evidence to suggest that this is indeed the case. ${ }^{213} \mathrm{~A}$ review of the case law arising under the Atomic Energy Act, RCRA, and the Federal Power Act shows a clear predominance of preemption outcomes in the early decisions under these statutes, followed by more decisions upholding state or local regulation later. ${ }^{214}$

Deference to the wishes of the current Congress is a more difficult concept to measure. One approach would be to examine decision outcomes as a function of partisan control of Congress. However, given the

210. One relatively recent and thorough explanation of this view is William Eskridge's theory of "dynamic" statutory interpretation. See William N. EsKridge, JR., Dynamic Statutory INTERPRETATION (1994), especially chapter 2.

211. This is precisely analogous to the idea that bureaucrats' faithfulness to legislative mandates is a function of "legislative drift," or the magnitude of the policy differences between the enacting and current Congresses. See Murray J. Horn \& Kenncth A. Shepsle, Commentary on "Administrative Arrangements and the Political Control of Agencies": Administrative Process and Organizational Form as Legislative Responses to Agency Costs, 75 VA. L. REv. 499 (1989); Kenneth A. Shepsle, Bureaucratic Drift, Coalitional Drift, and Time Consistency: A Comment on Macey, 8 J.L. Econ. \& ORG. 111 (1992).

212. See supra Part II.B.

213. We have too few cases in our sample to make any corresponding observation about Supreme Court cases.

214. See discussion supra Part II.B. A weaker but similar trend is evident in the TSCA cases as well. See supra Part II.B. 
difficulties associated with using party as an ideology proxy in these cases, ${ }^{215}$ that approach seeins unhelpful. ${ }^{216}$ Another approach would be to view decision outcomes as a function of public opinion on environmental, health, and safety issues, reasoning that Congress's policy preferences will be a function of popular preferences. This reasoning is sound for several reasons. First, scholars of Congress are almost unanimous in their acceptance of the proposition that the desire for re-election inakes legislators feel constrained by strongly held public opinion on salient issues. ${ }^{217}$ In addition, in this era of divided government, ${ }^{218}$ judges will correctly view the probability of an override as a function of public opinion more than legislators' preferences, to the extent that the two diverge.

Following this latter approach, then, the next problem is determining how to measure public pressure. After considering several alternatives, ${ }^{219}$ we chose a relatively general measure: the passage of tinie as a general proxy for the notion that support for environmental, health, and safety regulation (whether federal or at the state or local level) has increased over time. ${ }^{220}$ We considered using measures of public support for regulation that incorporated more year-to-year variance, such as annual or quarterly public opinion polling data. We rejected these data because they tend to vary as a function of a variety of short-term factors in which we are uninterested. ${ }^{221}$

215. See supra note 190 and accompanying text.

216. Furthermore, it would be difficult to assign a controlling party for those years in which control of Congress was split. In addition, partisan control of Congress would be a poor measure of the threat of a legislative override because it ignores the role of the President in that process.

217. There is a large bibliography within pohtical science. See, e.g., R. Douglas ARNold, THE Logic of Congressional action (1990); William T. Bianco, TRUSt: Representatives and Constituents (1994); Richard F. FenNo, JR., Home STyle: House MEMbers in Their Districts (1978); Morris P. FIorina, Retrospective Voting in American National Elections (1981); John W. Kingdon, Congressmen's Voting Decisions (1989); David R. Mayhew, Congress: The ELECTORAL CONNECTION (1974).

218. That is, we have had divided partisan control of the federal government (Congress and the presidency) for most of the period covered by our sample of cases.

219. In an earlier version of this analysis, we tried a measure that incorporated geographic variation in public support for environmental, health, and safety regulation-namely, voting scores assigned to members of Congress annualty by the League of Conservation Voters. See Spence, supra note 207 , at $11-12,18$. We ultimately decided not to use that measure. On the one hand, LCV scores did not appear to have any relationship to decision outcomes. Furthermore, while it is probably fair to view LCV scores as indicators of geographic variation in environmentalism, the scores are also influenced by the LCV's political objectives and other factors in which we are uninterested.

220. For a discussion of opinion on environmental issues and their general trends, see EVERETT Caril ladd \& Karlyn H. Bowman, AtTitudes Toward the Environment: Twenty-Five Years After EARTh DaY (1995); Riley E. Dunlap, Public Opinion and Environmental Policy, in Environmental Politics and Policy 87 (James P. Lester ed., 2d ed. 1995); Everett Carll Ladd \& Karlyn H. Bowman, Public Opinion on the Environment, 124 Resources 5 (1995).

221. Such data do trend upwards generally over the time period covered by our cases, but they vary considerably within that trend. We rejected that measure because that internal variance is often a function of particular issues that were in the news at the time individual polls were administered, the influence of question wording, partisan control of the executive branch, and more. For a discussion of these issues, see Dunlap, supra note 220 , at 87. 
We reasoned that courts will be more likely to see an override threat in this long-term change in public attitudes than in shorter-term variation in public opinion. ${ }^{222}$ Fortunately or not, in addition to serving as a proxy for judges' deference to the current Congress, this variable serves as a proxy for another, related political force that is usually implicit: the direct effect of public opinion on judges' decisions. If it is true that "the courts follow the election returns," 223 judges may be influenced by growing public environmentalism irrespective of their assessment of the threat of a legislative override..$^{24}$

Looking back at our discussion of the cases in Part II, it is difficult to discern any general pattern or trend in outcomes over time. ${ }^{225}$ More specifically, there does not appear to be a general increase or decrease in decisions upholding state or local regulation over time. ${ }^{226}$ If some underlying trend is being masked by other variables, however, the multivariate analysis should reveal it.

\section{c. Public Alarm}

Judges may be influenced by another implicit political variable: shorter-term, external political considerations. In particular, preemption cases raise the prospect that judges could be affected by intense local concern over the environmental, health, and safety risk at issue in the case. While nearly all of the cases in our sample provoked some sort of public outcry, or at least a certain background level of concern, only some cases concerned hazards that the public considered to be particularly alarming. We placed cases involving three substance-specific risks in the latter category, based upon the fact that these three risks (and only these three risks, among those in our sample) were specifically regulated by name in federal legislation. They are PCBs, asbestos, and radioactive waste. ${ }^{227}$

222. One counterargument to this is that judges may be responsive to particularly strong and intense shifts in short-term opinion. See infra Part III.B.2.c for a discussion of how we tried to account for that possibility.

223. MR. Dooley's OpInIons 26 (1901). This quotation has also been attributed to the political humorist Finley Peter Dunne by Bartlett's. See FamiLIAR Quotations 602 (John Bartlett \& Justin Kaplan, eds. 1992).

224. We cannot distiuguish those effects from one another here. As we discuss in Appendix B, infra, time also serves an important function in onr multivariate analysis, as a general proxy for omitted variables that vary over time.

225. We produced tables of decision outcomes by year, which revealed no particular trend over time (data not shown).

226. Once again, our sample of Supreme Court cases was too small to permit any corresponding analysis.

227. Eacl: of these thrce risks also garnered heightened levels of attention in weekly news magazines during the period covercd by our sample. The inclusion of asbestos in this list may seem mappropriate to soine now. However, at the time the asbestos cases in our sample wcre decided (in the mid-1980s), asbestos was the subject of considerable public concern and governmental attention. The federal statutes addressing radioactive waste arc the previously mentioned AEA, the Low-Level Radioactive Waste Policy Act of 1986, 42 U.S.C. $\$ \S 2021 \mathrm{a}-2021 \mathrm{j}$, and various specific statutes 
Were judges less likely to preempt local laws addressing these three issues? We see no evidence that this effect is present. Judges preempted state or local regulations about sixty-one percent of the time regardless of whether the case involved an alarm issue. ${ }^{228}$ Nor do we see any significant difference when the data are broken down by judges' party affiliations. ${ }^{229}$ It remains to be seen, however, whether the inultivariate analysis will reveal any evidence of an alarm issue effect.

\section{d. Deference to Federal Agency}

Among the explicit variables at work in some of the Supremacy Clause cases is the phenomenon of deference to the federal agency. ${ }^{230} \mathrm{Con}$ sistent with the Chevron doctrine, ${ }^{231}$ judges may accord great weight to the agency's interpretation of the statutory preemption provision. Since Commerce Clause cases do not involve statutory interpretation questions, this rationale for deferring to the agency applies only in Supremacy Clause cases. $^{232}$

In our sample, agencies rarely expressed their opinion on the preemption question. ${ }^{233}$ When they did, however, they appear to have swayed the courts. Recall froin Table 1, page 1161, that judges preempted state or local regulations about two-thirds of the tine, both in Supremacy Clause cases and Commerce Clause cases. However, in cases where the agency's position favored preeinption, judges agreed with the agency seventy-eight percent of the time. By contrast, where the agency's position favored upholding the state or local regulation, judges favored preemption only

addressing the siting of radioactive waste repositories. The federal statutes addressing asbestos risks are the Asbestos Information Act of 1988, 15 U.S.C. $\$ 2607$, the Asbestos Hazard Emergency Response Act of 1986, 15 U.S.C. $\S \$ 2641-2656$, and the Asbestos School Hazard Abatement Act, 20 U.S.C. \$\$ 4011-4022, among others. The federal statute addressing PCB risks is the Toxic Substances Control Act ("TSCA"), which contained a separate section specifying that (and to soine extent, how) the EPA should address PCB risks. See 15 U.S.C. $\$ 2605(\mathrm{e})$.

228. In an earlier analysis of a subset of Supremacy Clause decisions, we did notice differences in outcomes based on this variable. See Spence, supra uote 207, at 12-13, 18. That finding prompted our decision to examine the variable in this analysis.

229. We did uot examine the effect of alarm issues on Supreme Court decisions, since none of the decisions in our Supreme Court sample involved alarm issues.

230. Federal agencies expressed opirions on preeinption issues either by participating in the case as a party or amicus, or by other formal pronouneements, such as federal register notices.

231. See Chevron U.S.A. Inc. v. Natural Resourees Defense Couucil, Inc., 467 U.S. 837, 843, 844 (1984) (holding that when "Congress has not directly addressed the precise questiou at issue," when an agency is charged with administering a statute, its coustruction of that statute is controlling unless "arbitrary, capricious, or manifestly contrary to the statute").

232. Cross and Tiller inanitain that judges "manipulate Chevron for political effect" by applying its deferential standard only when it suits their policy preferences. Cross \& Tiller, supra note 183, at 2165; see also infra Appendix B (discussing this analysis).

233. They did so in about $15 \%$ of the cases, representing twenty-nine judges' decisions. Most of these cases were either HMTA cases in which the DOT was a party to the case, or TSCA cases for which the EPA had expressed its position on the preemption question in a Federal Register notice. See supra note 118 . 
thirty-six percent of the time. ${ }^{234}$ It appears, then, that in that small subset of cases where agencies take a position on the preemption question, that question is given some deference by the courts. ${ }^{235}$

\section{e. Relative Deference to State (vs. Local) Regulation}

Finally, we examine one additional characteristic of the cases: the question of whether the challengcd regulation was enacted at the state or local level. We might speculate that courts will be less willing, all else being equal, to preempt state regulations than local regulations, for several reasons. Judges may simply believe that the law of the larger jurisdiction is entitled to more weight, and that preempting a state law overrides the interests of a far larger number of people than preempting a local law. In addition, judges may see local regulations as the expressions of impassioned NIMBY groups whose members are numerous enough to persuade local governments but not state governments. ${ }^{236}$ In other words, judges may believe that there is a greater chance that local laws do not represent broadly held, or even majority, views.

Table 9: State vs. Local Regulation Decisions a Preempting Local REgulation

\begin{tabular}{|c|c|c|}
\hline & $\begin{array}{c}\text { Cases Involving State } \\
\text { Regulation }\end{array}$ & $\begin{array}{l}\text { CASES INvolving } \\
\text { Local REgulation }\end{array}$ \\
\hline DEMOCRATS & $54 \%$ & $69 \%$ \\
\hline REPUbliCANS & $65 \%$ & $61 \%$ \\
\hline $\begin{array}{c}\text { ALL } \\
\text { DECISIONS }\end{array}$ & $61 \%$ & $64 \%$ \\
\hline
\end{tabular}

a Each judge's vote constitutes a separate decision.

No "increased deference to state law" effect is evident in Table 9, page 1178 , when we consider the sample as a whole. However, we do see an effect when we look only at the decisions of Democrats. Republicans

234. We found no difference between Democrats and Republicans on this issue.

235. Our sample of Supreme Court decisions had too few of these cases to make any meaningful comparisous.

236. As we noted, supra Part III.A.1, there is another reason to expect judges to preempt local laws more often. That is that local governments may be more likely to pursue cases having a low probability of success because of their greater responsiveness to political pressure. In other words, our potential pro-preemption sample bias problem may be more severe in cases involving local regulation than state regulation. 
have remained relatively consistent, preempting both state and local laws about two-thirds of the time. Democrats, however, preempt state laws only fifty-four percent of the time while preempting local laws sixty-nine percent of the time. This characteristic of the case appears to influence Democrats' decisions. ${ }^{237}$

In conclusion, some of the external variables appear to shed light on this jurisprudence. In particular, the last two variables-deference to federal agencies and whether the prospectively preempted law is a state or local law-seem particularly promising. The multivariate analysis should confirm or deny these effects, and it could reveal others.

\section{Testing the Theories: A Multivariate Analysis}

As we have noted, our review of the bivariate relationships between these independent variables and judges' decisions suggests that there may indeed be some discernible patterns in this preemption jurisprudence. It also suggests some directions for further inquiry in our multivariate analysis. Of course, we cannot be certain that the bivariate relationships we have observed are not spurious or that unobserved variables are not inasking the relationship between the variables. Only by examining the simultaneous effect of all the independent variables on judges' decisions can we get a sense of whether these relationships are genuine. The inultivariate statistical analysis permits us to do just that.

Our statistical analysis employs an estimation technique, known as "logit," that is now commonly used by legal scholars and others to analyze judicial decisions. ${ }^{238}$ Our logit model will produce estimates of the

237. The Supreme Court data reveal a strong effect in the opposite direction, with the judges voting to preempt state laws $87 \%$ of the time and local laws about $12 \%$ of the time. However, we cannot read much importance into these percentages, since they are based on two cases involving local laws and five cases involving state laws. The two cases involving local laws were $C \& A$ Carbone, Inc. v. Town of Clarkstown, 511 U.S. 383 (1994), and Wisconsin Pub. Intervenor v. Mortier, 501 U.S. 597 (1991).

238. The "logit" or "logistic regression" technique has long been used by social scientists to analyze non-continuous or categorical variables, like binary decisions. For a full discussion of the statistical methods, see Appendix B, notes 287-89, infra. Logit is one of several such "inaximum likelilrood" techniques. These techniques have been used in traditional legal scholarship for more than a decade, and are now quite commonly used to analyze a wide variety of legal issues in that setting. See, e.g., Leonard Bierman et al., The Community Reinvestment Act: A Preliminary Empirical Analysis, 45 Hastings L.J. 383 (1994); Margaret F. Brinig, Comment on Jana Singer's Alimony and Efficiency, 82 GEo. L. J.2461 (1994); Stephen Calkins, Summary Judgment, Motions to Dismiss, and Other Examples of Equilibrating Tendencies in the Antitrust System, 74 GEO. L.J. 1065 (1986), Cross \& Tiller, supra note 183; Theodore Eisenberg \& Stefan Sundgren, Is Chapter 11 Too Favorable To Debtors? Evidence from Abroad, 82 CORNELl L. REv. 1532 (1997); James Todd Kennard, Practitioner's Corner: Lawyers, Sex, and Marriage: Factors Empirically Correlated with the Decision to Settle, 2 HaRv. Negotiation L. Rev. 149 (1997); Roberta Romano, Public Pension Fund Activism in Corporate Governance Reconsidered, 93 ColuM. L. REv. 795 (1993); Howard Slielanski, Comment, Robinson-Patman Act Regulation of Intraenterprise Pricing, 80 CALIF. L. REv. 247 (1992); 
relationship between each explanatory variable and each dependent variable, the judges' decisions. The model will also produce estimates of the probability that the relationship observed is due only to chance. ${ }^{239}$ The analysis will include an examination of each of the internal and external variables we have identified. Our internal variables include each jndge's PARTy affiliation, whether the judge is a REAGAN Appointee, the CoAsean Position on the disputed issne in the case, and the Pigovian Position on the disputed issue in the case. Our external variables include the CASE Type (Supremacy Clause or Commerce Clause), the type of STATE OR LOCAL REGULATION at issue (state law or local law), the federal AGENCY Position on the preemption issue, if any, whether the case involves an ALARM IsSUE, and two ineasnres of strategic or political variables. The first of these, TIME, serves as a proxy for the gradual increase in societal environmentalism over time. ${ }^{240}$ The second, Time DisTance, applies only to Snpremacy Clause decisions and represents the passage of time between the date of the decision and the date of the passage of the federal statute being interpreted. This variable serves as our measure of the extent to which judges' deference to the pro-preemption wishes of the enacting Congress inay wane with time. ${ }^{241}$

The bivariate analysis suggests that we ought to include some additional variables in this analysis to account for some of the interactions between explanatory variables observed there. Among the internal variables, we include measures of whether the Pigovian or Coasean philosophy of regulation exerts particular influence over those whom we would expect to be most susceptible to that influence. Thus, we include a Pigovias DEMOCraT variable that reflects the Pigovian position only when the judge is a Democrat, a COASEAN REPUBLICAN variable that reflects the Coasean position only when the judge is a Republican, ${ }^{242}$ and a Coasean Reagan

Vicki Schultz \& Stephen Petterson, Race, Gender, Work, and Choice: An Empirical Study of the Lack of Interest Defense in Title VII Cases Challenging Job Segregation, 59 U. CHI. L. Rev. 1073 (1992).

239. The model produces estimates of the effect of these variables on the probability of a particular judicial decision. In this case, the two choices are, of course, the decision to preempt, or not to preempt, the state or local regulation; we will model the probability of a decision to preempt, see Appendix B, infra. The model produces estimates of the direction of the effects (a positive or negative variable coefficient), the magnitude (the size of the coefficient, indicating how much the variable changes the probability of an outcome) of the effects, and the probability that these coefficient estimates are due only to chance (typically called the "probability of error"). We typically reject coefficient estimates where the probability of error exceeds a spccified threshold, usually .1 or .05 in social science contexts.

240. As we have noted, this variable also serves as a proxy for any other omitted variable that might vary predictably with time.

241. For an explanation of the coding of these variables, see infra Appendix B.

242. This refers to all Republican appointed judges, not just non-Reagan appointee Republicans, as in Table 6, page 1169. 
Appointee variable, that reflects the Coasean position only when the judge is a Reagan appointee. ${ }^{243}$

Table 10, pages 1182-83, which summarizes the ineaning of the possible relationships between our explanatory variables and the dependent variable, judges' decisions, raises two issues worth addressing before presenting the results of our multivariate analysis. First, as was the case in our bivariate analysis, we inust use the first two of our internal variables (Party and Reagan Appointee) as proxies for two ideological dimensions at once. That is, each must serve as a proxy both for the judges' philosophy of federalisin and policy preferences. However, because we include separate ineasures of our third ideological dimension, we can once again use these two variables to infer judges' true ideological motives when they "go against type." ${ }^{44}$ Thus, if the model produces a statistically significant coefficient for either, we can infer that one or the other of these dimensions overpowered the other. On the other hand, if the model does uot produce a statistically significant estimate for one or both, we probably cannot infer the nonexistence of a relationship, because the two ideological dimensionsexert countervailing effects on these proxy variables. ${ }^{245}$ Second, as the second column in Table 10, pages 1182-83, implies, we will focus our attention on the existence of statistically significant effects, and their direction, rather than on the magmitude of those effects. We do so in part because our ideological variables are merely indicators, meaning that we use thein primarily to determine the direction of any association they inay have with the dependent variable. For example, a positive coefficient for

243. These and other interaction variables were coded as explained in Appendix B, infra. Note that each was coded so as to vary only in cases where the deciding judge had the particular party affiliation in which we were interested. In such cases, the variable varied with the corresponding philosophy of regulation (Coasean or Pigovian) variable in which we were interested. For cases where the deciding judge had the other party affiliation, the variable held a constant, non-zero, middle value.

In another version of our analysis, we included an interaction variable suggested by Table 9: State or local Regulation, Democrats ONLy, page 1178, which isolated those decisions involving preeinption of state (vs. local) law and Deinocratic judges. We opted not to include it in the final model for two reasons. First, it appeared to perform as a substitute for the STATE OR LOCAL Regulation variable. That is, when the Democrats ONLY version of the variable is excluded, the STATE OR LOCAL REgULATION variable produces a negative, statistically significant effect. When the DEMOCRATS ONLY variable is imcluded in the analysis, it produces a negative, statistically significant effect while the STATE or LOCAL REgulation variable does not. Second, the inclusion of the DEMOCRATS ONLY variable does not improve the performance of the model. Hence, we elected to exclude it.

244. See supra p. 1171 tbl.8 and accompanying text.

245. Technically, we cannot infer the nonexistence of a relationship using this kind of hypothesis testing anyway. The model will enable us to infer the existenee of a relationship when statistically siguificant coefficients are produced. We do so beeause we can reject (with 90,95 or $99 \%$ confidence) the hypothesis that the result is due to chance. When the model does not produce a statistically significant coefficient estimate, that simply refiects the fact that our confidence level has fallen below the applicable threshold. Thus, we are testing for the existence of a relationship, not the nonexistence of one, and a negative result does not permit an inference that no relationship exists. Rather, it simply means that we could not prove its existence. 
the Coasean Position variable indicates that judges acted consistently with the Coasean Position. It does not tell us much else about those effects. Therefore, interpreting the inagnitude of the effects represented by the coefficients of indicator variables and, by implication, many of the interaction variables is difficult. ${ }^{246}$

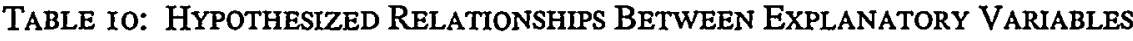 AND DECISION OUTCOMES}

Internal/leology Variables

\begin{tabular}{|c|c|}
\hline VARIABLE & HYPOTHESIZED RELATIONSHIP \\
\hline PARTY (DEMOCRAT) & $\begin{array}{l}\text { Positive sign implies that Democrats are more likely to } \\
\text { preempt, and that philosophy of federalism is determin- } \\
\text { ing decisions; negative sign ineans Republicans are } \\
\text { more likely to preempt, and that policy preferences are } \\
\text { driving decisions. }\end{array}$ \\
\hline REAGAN APPoINTEe & $\begin{array}{l}\text { Positive sign implies Reagan appointees are more likely } \\
\text { to preempt (federalism reasons); negative sign implies } \\
\text { the opposite (policy reasons) }\end{array}$ \\
\hline $\begin{array}{l}\text { COASEAN POSITION } \\
\text { (INDICATOR) }\end{array}$ & $\begin{array}{l}\text { Positive sign implies judges follow the Coasean posi- } \\
\text { tion; negative sign implies the opposite }\end{array}$ \\
\hline $\begin{array}{l}\text { Pigovian Position } \\
\text { (INDICATOR) }\end{array}$ & $\begin{array}{l}\text { Positive sign implies judges follow the Coasean posi- } \\
\text { tion; negative sign implies the opposite }\end{array}$ \\
\hline
\end{tabular}

246. Our logit analysis models the dependent variable as the probability of a decision to preempt state or local regulation. In the usual case, the effect of any given explanatory variable on that probability is calculated by holding all other independent variables at their means, and varying the independent variable of interest in the equation given infra, Appendix B. However, we are using the interaction variables to isolate the variation of one variable (the Coasean position) on the decisions of particular judges. Those interaction variables have been coded in ways which have little real world meaning. Thus, interpreting the magnitude of their effects is difficult. Of course, an observed relationship between the dependent variable and any independent variable does not imply causation. The logit analysis, like all regression analyses, measures the degree to which the dependent variable differs with the independent variable. The independent variable coefficient estimates are measures of the direction (positive or negative) and strength of that relationship. While we can use theory and intuition to draw educated inferences about causation, the logit analysis does not demonstrate or measure the direction of causation. 
Ideological Interaction Variables (Indicators)

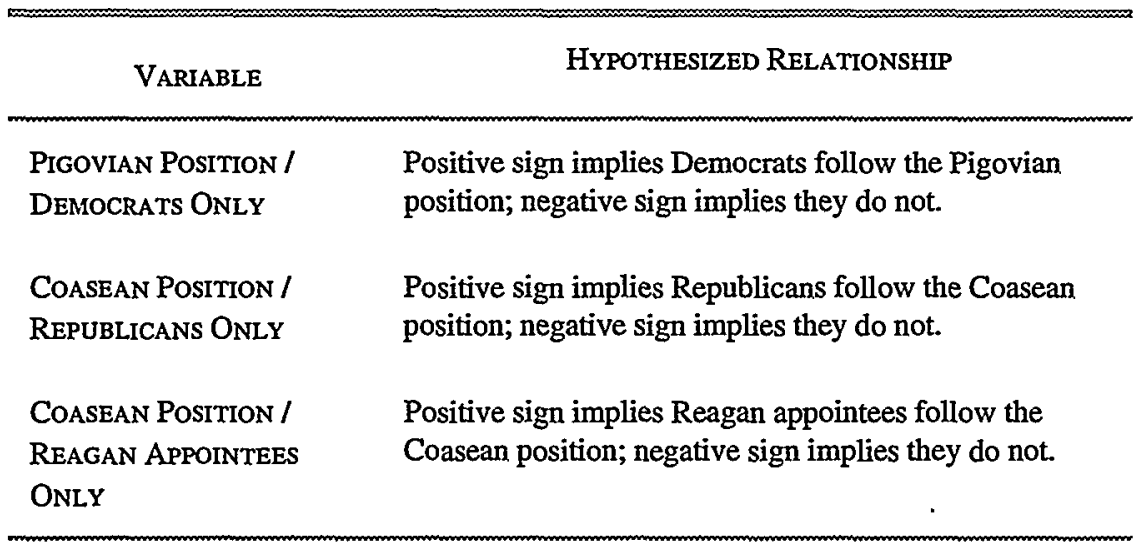

\section{External Variables}

VARIABLE

CAse Type (CONTroL)

STATE OR LOCAL

REgULATION

Federal Agency

POSITION $^{a}$

ALARM Issue

INVOLVED?

TIME

Time Distance ${ }^{a}$
HYPOTHESIZED RELATIONSHIP

Positive sign implies judges are more likely to preempt in Supremacy Clause cases; negative sign implies opposite.

Negative sign implies that judges are less likely to preempt state regulations than local regulations.

Positive sign implies that judges follow the position of the responsible federal agency on the preemption issue involved.

Negative sign means that judges are less likely to preempt laws regulating alarming issues.

Negative sign implies that increasing societal environmentalism has decreased the probability of preemption, either directly or via judges' concern that Congress will overrule and anti-environmental decision. Positive sigu implies the opposite.

Negative sign implies that judges grow less likely to preempt state or local regulation as date of passage of the applicable federal statute grows more remote in time.

\footnotetext{
a Applies only to cases arising under the Supremacy Clause.
} 
Table 11, page 1186 , presents the results of our model, ${ }^{247}$ which suggests that policy preferences play a role in preemption decisions. We have provided the direction of each estimated effect, with the statistically significant effects in bold, italicized type. Looking at the internal/ideological variables (Table 11, page 1186), the results appear to confirm some of the trends we observed in Tables 5-8. First, controlling for the effects of other variables, the negative coefficient on the Party variable means that Republicans were inore likely to preempt state or local regulations than were Democrats. Because we do not expect Democrats to be more sensitive to states' rights than Republicans, we can infer that judges' policy preferences do influence their decisions in these preemption cases. ${ }^{248} \mathrm{We}$ cannot ascribe this result to the effects of judges' philosophies of regulation, since we have controlled for those effects in this model.

At the same time, Reagan appointees were less likely than other judges to preempt local regulations generally, and more likely to follow the Coasean position than other judges. These results offer a clearer picture of the differences between Reagan appointees and other judges implied by Tables 5 , page 1168 , and 6 , page 1169 . Reagan appoimtees, as a subset of all judges, appear less likely than their colleagues to be guided by their policy preferences; rather, they appear more likely than other judges to be guided by their philosophy of regulation and their philosophy of federalism in these decisions. Both of these effects help explain why Reagan appointees tend to preempt state and local regulation less frequently than their Republican colleagues. Conversely, as Tables 6 , page 1169 , and 8 , page

247. We have provided the actual coefficient estimates, as well as information about the model's overall performance in Appendix B, infra.

248. Cross \& Tiller, supra note 183 , at $2164-75$, suggest that, at the circuit court level, the tendency of judges to follow their policy preferences may be mediated by the partisan makeup of the panel. They found that that the presence of a "whistleblowcr" minority member on the panel dissuades a inajority inclined to follow its policy preferences (and to disobey Supreme Court precedent) from doing so. Our analysis differs from theirs in several important ways. First, we are not explicitly modeling adherence to precedent. Second, our sample consists of both circuit court and cistrict court decisions, the latter of which are issued by a single judge. Nevertheless, we looked for évidence to support their thesis. Our thiry-eight panel decisions broke down as follows:

\begin{tabular}{lccccc} 
OUTCOME & 3 GOP & $2-1$ GOP & $2-1$ DEM & 3 DEM & TOTALS \\
\hline LOCAL LAW PREESITED & 6 & 14 & 5 & 1 & 26 \\
LOCAL LAW UPHELD & 0 & 7 & 4 & 1 & 12 \\
\hline TOTALS & 6 & 21 & 9 & 2 & 38
\end{tabular}

If we assume for the moment that policy preferences motivate the judges more thau do other ideological forces, we see some evidence in support of Cross and Tiller's thesis. It appears that uuanimous Republican panels did pursue their ideological preferences more often than split Republican-majority panels. No such effect was present among Democrats, however. Two caveats are in order, lowever. First, we should be cautious about attempting to draw inferences from a small sample, particularly in connection with Democrat-dominated panels. Second, we should acknowledge that this kind of analysis does not control for other explanatory variables. 
1171 , imply, the other side of the story is that non-Reagan appointee Republicans exhibit relatively less Coasean behavior, as evidenced by the negative coefficient on the COASEAN POSITION/REPUBLICANS ONLY variable. That is, even though Republicans generally are more likely than Democrats to preempt state or local regulations, only Reagan appointees appear to be motivated by their philosophical preference for private solutions to externality problems. Other Republicans show no such loyalty to that philosophy. ${ }^{249}$

Among the remaiming internal variables, the two general philosophy of regulation variables had statistically significant coefficients of opposite signs. These variables were designed to measure whether, as a group, the judges in our sample tended to follow the Coasean and Pigovian prescriptions. These data indicate that they tended to follow the former but not the latter. In other words, judges were more likely to preempt laws that forced the internalization of environmental costs and less likely to preempt laws that promoted private solutions to externality problems. These results are consistent with the bivariate analysis and may be an artifact of the bias in our sample toward preemption outcomes, because the Coasean position generally favors preemption while the Pigovian position does not. ${ }^{250} \mathrm{On}$ the other hand, additional evidence suggests that the Pigovian philosophy held little sway in these decisions. The model does not support the existence of the small Pigovian Democrat effect we saw in Table 7, page 1170; rather, the coefficient for that variable is neither statistically significant nor in the expected direction, implying that Democrats were not more likely to favor state or local regulations that required the internalization of environmental costs.

249. Indeed, the negative coefficient on our CoAsean Position/Republicans ONLY variable implies that Republicans as a group are relatively anti-Coasean (controlling for the relatively Coasean behavior of Reagan appointees). It seems unlikely, however, that Republicans were truly anti-Coasean. For now, this is one of the mysteries of this jurisprudence that remains unsolved. We do not have a good explanation for this result. We checked for the possibility that the CoASEAN Position/REAGAN APPOINTEE variable was stealing the thunder of this variable, causing this counterintuitive result. That does not appear to be the case, since the sign of its coefficient does not change when the other variable is excluded. The Coasean position favors preemption generally, except in cases involving local rightto-know laws. See our explanation of variable coding in Appendix B, infra. Cases involving local rightto-know laws arose under Supremacy Clause preemption cases, specifically certain FIFRA and OSHA preemption cases. Since the model indicates that judges as a group tended to follow the Coasean position, and that Reagan appointees tended to follow the Coasean position, we can speculate that nonReagan appointee Republicans were more likely to preeınpt in FIFRA and OSHA preeinption cases than in other cases. Why this is the case we do not know.

250. Sometines when variables that comprise parts of interaction variables are part of the same model as the interaction variables, the signs of the coefficients of the former can be reversed. We performed a check for that possibility by running subset models which excluded the interaction variables, and ruled out that possibility here. 
Table it: Results-Relationships Between Explanatory Variables and DECISION OUTCOMES

\begin{tabular}{|c|c|c|c|c|c|}
\hline \multicolumn{2}{|c|}{ Internal/deology Variables } & \multicolumn{2}{|c|}{$\begin{array}{c}\text { Ideological Interaction } \\
\text { Variables (Indicators) }\end{array}$} & \multicolumn{2}{|c|}{ External Variables } \\
\hline VAR. & COEFF. ${ }^{251}$ & VAR. & COEFF. & VAR. & COEFF. \\
\hline $\begin{array}{l}\text { PARTY } \\
\text { (DEMOCRAT) }\end{array}$ & $\begin{array}{l}\text { Neg. } \\
(p<05)\end{array}$ & $\begin{array}{l}\text { Pigovian } \\
\text { Position / } \\
\text { DEMOCRATS } \\
\text { ONLY }\end{array}$ & Neg. & $\begin{array}{l}\text { CASE TYPE } \\
\text { (CONTROL) }\end{array}$ & $\begin{array}{l}\text { Pos. } \\
(p<1)\end{array}$ \\
\hline $\begin{array}{l}\text { REAGAN } \\
\text { APPOINTEE }\end{array}$ & $\begin{array}{l}\text { Neg. } \\
(p<05)\end{array}$ & $\begin{array}{l}\text { COASEAN } \\
\text { POSTITON / } \\
\text { REPUBLICANS } \\
\text { ONLY }\end{array}$ & $\begin{array}{c}\text { Neg. } \\
(p<05)\end{array}$ & $\begin{array}{l}\text { STATE OR } \\
\text { LOCAL } \\
\text { REGULATION }\end{array}$ & $\begin{array}{c}\text { Neg. } \\
(p<05)\end{array}$ \\
\hline $\begin{array}{l}\text { COASEAN } \\
\text { POSITION } \\
\text { (INDICATOR) }\end{array}$ & $\begin{array}{c}\text { Pos. } \\
(p<05)\end{array}$ & $\begin{array}{l}\text { COASEAN } \\
\text { Position / } \\
\text { REAGAN } \\
\text { APPOINTEES } \\
\text { ONLY }\end{array}$ & $\begin{array}{c}\text { Pos. } \\
(p<05)\end{array}$ & $\begin{array}{l}\text { Federal } \\
\text { AgEnCy } \\
\text { Position }\end{array}$ & $\begin{array}{c}\text { Pos. } \\
(p<05)\end{array}$ \\
\hline $\begin{array}{l}\text { Pigovian } \\
\text { Position } \\
\text { (INDICATOR) }\end{array}$ & $\begin{array}{l}\text { Neg. } \\
(p<05)\end{array}$ & & & $\begin{array}{l}\text { ALARM ISSUE } \\
\text { INVOLVED? }\end{array}$ & Neg. \\
\hline & & & & $\begin{array}{l}\text { TIME } \\
\text { Time } \\
\text { Distance }\end{array}$ & $\begin{array}{l}\text { Pos. } \\
\text { Neg. } \\
(p<I)\end{array}$ \\
\hline
\end{tabular}

Among the external variables (Table 11, page 1186), several performed well in this analysis, and all of their statistically significant effects were in the direction implied by the bivariate analysis. First, consistent with the idea that case characteristics matter, judges were indeed more likely to preempt local, as opposed to state, laws, as implied by Table 9 , page 1178 . This result may reflect either greater deference to the latter or the tendency of local governments to pursue losing cases, ${ }^{252}$ or some

251. Statistically significant results are italicized. The "probability of error" is one way of expressing the statistical significance of these estimates. The expression "p<.05" means that the probability that the observed effect (of the independent variable on the dependent variable) is due to random change is less than .05 . It is common to say that where the probability of error is less than .1, .05 , or .01 (depending on the context), the observed result is "statistically significant." However, these cut-off values are chosen arbitrarily or by convention.

252. See discussion of this issue supra note 178 and accompanying text. 
combination of the two. ${ }^{253}$ It also appears that judges tended to defer to the positions taken by federal agencies on preemption questions. We can speculate that this latter result is attributable to the fact that judges give weight to agency expertise when imterpreting federal statutes the agency is charged with administering. ${ }^{254}$

Second, it appears that the probability of a preemption outcome in Supremacy Clause cases is greater than that in Commerce Clause cases, as Table 1, page 1161, implies. Moreover, that probability decreases as the underlying federal statute grows more remote in time. This latter effect implies decreasing deference to the enacting Congress over time. It may also reflect judges' perceptions that the probability that Congress will overrule a decision upholding a state or local regulation decreases with time, ${ }^{255}$ though the insignificance of the TIME variable belies that conclusion. In either case, this result is consistent with the idea that strategic political (or institutional) considerations do play a role in judges' decisions. ${ }^{256}$

IV

\section{IMPLICATIONS}

\section{A. Implications for Preemption Doctrine}

For a variety of reasons, the majority of judges on the federal bench appear to be predisposed to preempt state and local regulation of environmental, health, and safety regulation. Federal judges have fostered, consciously or unconsciously, a national private market for pollution externalities; at the same time, they have hampered local efforts to address local environmental, health, and safety concerns. The importance of those local concerns is underscored by the repeated attempts of state and local governments to continue to regulate in the face of evolving preemption doctrine. While most of those attempts ultimately fail, our analysis implies that the probability of success may be a function not only of the characteristics of the judge(s) decidimg the case, but also of factors that proponents of regulation may be able to influence, such as the level of government at which the regulation is enacted.

253. We looked for ways to try to identify "futile" cases, in order to separate these two possible effects. Unfortunately, there was nothing in the opinions or other case characteristics that enabled us to do so. If we can assume that judges will identify futile cases in their opinions, the absence of such language implies that judges do defer more to state laws than local laws. However, we do not believe that that is a safe assumption, and so we hesitate to draw that conclusion.

254. See supra notes 230-32 and accompanying text.

255. See supra notes 208-11 and accompanymg text.

256. Neither of the variables designed to measure direct political pressure-the TIME variable or the ALARM Issue variable-produced statistically significant effects, though the ALARM Issuevariable coefficient had the expected negative sign; had the coefficient cstimate been statistically significant, it would have implied a decreased probability of preemption when alarm issues are involved. 
We have noted that critics lament the unwillingness of judges to permit states and localities to force the internalization of environmental costs, while defenders support the courts' refusal to permit imterference with the inarket's allocation of those costs. ${ }^{257}$ While our analysis cannot resolve the debate, it can help to illuminate the role of politics in the argument, including its influence on judicial resolution of preemption disputes. First, while Coaseans are undeniably correct that states and localities have incentives to regulate inefficiently, we note some problems with the Coasean analysis. We break no new ground in observing that Coaseans employ vulnerable assumptions in their defense of current preenution doctrine. In particular, there are serious problems associated with reliance on willingness to pay, or willingness to accept compensation, as a gauge of social welfare. ${ }^{258}$ In practice, we typically ineasure that willingness in the price paid by the generator of the externality to another to accept the externality (landfill disposal costs, for example). However, disposal costs are a poor translator of society's willingness to pay to avoid environmental costs. ${ }^{259}$ Depending on the laws of the importing state, disposal costs may reflect only the interests of a single disposal facility operator. If nearby residents bearing some of the environmental costs cannot use the legal or political process to assert their rights, disposal fees will ignore their interests. In addition, even if we could measure everyone's willingness to pay to avoid the externality, that price will be a function of their ability to pay, which means that the intense preferences of the poor are assigned a lower value than the mild preferences of the rich. ${ }^{260}$ This is a well-established criticism of the equation Coaseans sometimes make between efficiency and equity.

257. See supra Part II.C.

258. This issue is the subject of a great deal of scholarly attention. See, e.g., RoNALD DwORKIN, Is Wealth a Value?, in A MATTER of PRINCIPLE 237, 242-46 (1985); Herbert Hovenkamp, Marginal Utility and the Coase Theorem, 75 CoRnell L. Rev. 783 (1990); Herbert Hovenkamp, Positivism in Law and Economics, 78 CALIF. L. Rev. 815, 840 (1990) ("Two people with precisely the same willingness to pay may have very different utility functions."); Joshua D. Sarnoff, A Reply to Professor Revesz's Response in "The Race to the Bottom in Federal Environmental Legislation," 8 DUKE ENvTL. L. \& POL'Y F. 295, 298 (1998) ("[W]e cannot directly measure such willingness-to-pay, because economic markets do not exist in which individuals pay regnlators to regulate.").

259. See, e.g., Engel, supra note 140, at 1505 (noting social costs "external to those covered by the tipping fees charged by private waste disposal operators," including impacts on property valucs, health, natural resources, and more). The Coasean response is that landowners would pay the facility owner not to accept waste if they valued removing the facility highly enough. This, of course, assuncs the absence of transaction costs associated with bargaining, an assumption which is rarely borne out in practice.

260. A common way of illustrating how willingness to pay fails to measure accurately the intensity of preferences is the example of two people who want a carton of milk. One is a destitute man who wants the milk to feed his family; the other is a wealthy man who wants the milk so he can pour it down the drain (beeause he likes the sound it makes). The poor man is willing to pay his last dollar for the milk, while the rich man is willing to pay \$1.50. In this case, the rich man's greater "willingness to pay" seems a poor reflection of the relative value each places on the milk. As others have noted, the Coase Theorem ignores these distributional concerns. However, they are very real conccrns in this context, given the income disparities between exporting and importing states. For a good discussion of 
Second, and more importantly, the Coasean argument ignores the political distortions that already exist im the absence of government-imposed solutions to these problems. The current interstate market for externalities is driven, in part, by disparities im political sophistication and clout. Exporting states are able to export environmental costs partly because politically powerful NIMBY groups can prevent the development of new disposal capacity, if not through litigation then through the exercise of political influence. Conversely, the relative lack of political sophistication and clout exhibited by prospective NIMBY groups in importing states partly accounts for their greater disposal capacity and ability to import environmental costs. ${ }^{261}$ Thus, the relationship between disposal costs and social welfare is mediated by politics, and externalities inoving in commerce may be following the path of least political resistance. ${ }^{262}$ Our analysis suggests that that path, in turn, is being shaped by federal judges who are predisposed to preempt state or local regulation, partly for political reasons. Regardless of whether judges decide these cases on policy grounds or to effect a Coasean solution to these problems, the irony is the same. Judges are issuing decisions striking down (state and local) legislative solutions, thereby imposing a market solution that has itself been distorted by politics.

Third, one way judges could do a better job of acknowledging and addressing the political distortions in the market for externalities is by taking a more Pigovian view, one that distinguishes between state or local regulations that represent attempts to force a balancing of social benefits and costs, on the one hand, and mere attempts to shift costs, on the other. Cost-internalizing local laws ought to be better gauges of social welfare than disposal costs, not only because they force more of a balancing of benefits and costs, ${ }^{263}$ but also because they are the product of a more

the relationship between willingness to pay and ability to pay in Coasean theory, see Richard Schmalbeck, The Justice of Economics: An Analysis of Wealth Maximization as a Normative Goal, 83 Colum. L. REv. 488, 502 (1983) (book review).

261. See Engel, supra note 140, at 1492 ("[T] eventually 'free ride' off of the landfill space remaining in other states."); see also supra note 142 (discussing others who attribute success to NIMBY movements).

262. This is exactly what James Hamiltou found to be the case in his analysis of dccisions by hazardous waste facilities to expand their operations. He found that levels of political activism were negatively associated with the probability of expansion, controlling for socioeconomic and other factors. See James T. Hamilton, Politics and Social Cost: Estimating the Impact of Collective Action on Hazardous Waste Facilities, 24 RAND J. EcoN. 101 (1993); James T. Hamilton, Testing for Environmental Racism: Prejudice, Profits, Political Power?, 14 J. PoL'Y. ANALysis \& MGMt. 107 (1995); see also Been, supra note 55, at 1002 ("[S]iting decision makers often take the path of least resistance-choosing sites in neighborhoods that are least likely to protest effectively.").

263. See Revesz, Rehabilitating Interstate Competition, supra note 54, at 1233-35, $1244-47$. However, Dan Ingberman has deinonstrated that if we rely on local governments to translate social costs and benefits into policy, they will do so imperfectly because the one-person-one-vote rule cannot account for variations in the intensity of preferences. Since costs are concentrated on a few and benefits are widely distributed, a majority will favor accepting the externality despite its possibly negative net 
inclusive collective choice ${ }^{264}$ and avoid the equity problems surrounding disparities in ability to pay. ${ }^{265} \mathrm{It}$ is for all these reasons that cost-shifting regulation-not cost-internalizing regulation-seems analogous to the kind of protectionist barriers about which the founding fathers were concerned. If more judges distinguished between these two types of state and local regulation in their preemption decisions, the result would be a more efficient allocation of externalities. ${ }^{266}$ However, this seems unlikely to happen. The poor performance of Pigovian variables in our analysis indicates that federal judges do not distinguish Pigovian from other state or local regulations in their preemption decisions.

Some judges ${ }^{267}$ and commentators ${ }^{268}$ point to legislative solutions as an alternative way to better match the distribution of costs and benefits to the locus of decision-making power. These proposals include congressional action to authorize state and local regulation of externality flows in the market, or other congressional action to minimize cost-shifting in the political process. While these actions might represent an improvement over the status quo, they also bring their own set of problems. First, legislation designed simply to authorize state and local waste regulation seems an insufficient response. Leaving the policy initiative with local governments invites cost-shifting state and local laws. Second, while it is theoretically possible that Congress could write a legislative rule that would permit local cost-internalizing regulation but would prohibit local cost-shifting regulation, writing such a rule would be difficult. Our analysis suggests that such a law will be vulnerable to interpretation by judges unsympathetic with its Pigovian mission. ${ }^{269}$ Perhaps that danger could be overcome by legislative specificity; however, with greater specificity come all the dangers associated with reliance on overly-specific rules. Any rnle that tries to provide specific direction can produce unintended consequences when applied to

impacts. However, Ingberman also demonstrates that this effect is exaccrbated by the powerful incentive to shift costs to others outside the jurisdiction. See Ingberman, supra note 54, at S-20.

264. In other words, they involve the (putative, at least) input of all voters, whereas the disposal price does not reflect even the potential input of all societal interests.

265. The counterargument that the market translates prefercnces bctter than politics seems weakest in these instances, because the distortions in the former seem particularly imposing here.

266. As we discussed earlier, this is precisely the argument made by Justice Rehnquist in his dissent in Fort Gratiot Sanitary Landfill, Inc. v. Michigan Department of Natural Resources, 504 U.S. 334, at 355-57, 361-68 (Rehnquist, C.J., dissenting). See supra note 155.

267. See supra Part II.A.l (discussing Justice O'Connor's opinion in C\&A Carbone, 511 U.S. 383).

268. See infra note 140 (discussing Kirsten Engel's proposal). Butler and Macey argue for Coasean bargaining by local governments, rather than individuals. However, it is not clear whether their prescription requires federal legislation or that it would force the internalization of costs, even at the local government level. See Butler \& Macey, supra note 54.

269. The fact that some components of the traditional model of judging played a role in our model might suggest that a well-written fedcral law would be dutifully interprctcd by judges. But such a law would either leave judges with discretion to pursue their policy preferenccs or will entail other problems associated with overly specific statutes. See infra note 270. 
unforeseen circumstances. ${ }^{270}$ Greater specificity would make the law less politically palatable as well. As we have seen, states that export their environmental costs have been able to exert sufficient influence in national politics to prevent national legislation on waste management to date. ${ }^{271}$ In other words, any substantive congressional solution is itself subject to still more political distortions of the type the Coasean analysis ostensibly avoids.

The preferable solution, in our opinion, is one that combines a Pigovian decision rule with case-by-case decision making. There are several ways this could be done. ${ }^{272}$ Were they so mclined, federal judges could do the job of implementing Pigovian solutions via a case-by-case review of state and local laws; however, our analysis indicates that they are not so inclined. Absent that option, the next best alternative would be to delegate the task of applying the Pigovian decision rule to the EPA. Specifically, two relatively small steps could go a long way toward eliminating inefficient distortions in the market for externalities. First, the EPA could explicitly incorporate the Pigovian criterion into its oversight of existing permitting programs ${ }^{273}$ by requiring permitting agencies to internalize the external costs associated with siting new facilities. ${ }^{274}$ Second, the EPA's

270. The literature on the optimal specificity of law is also large. See generally Colin S. Diver, The Optimal Precision of Administrative Rules, 93 YALE L. J. 65 (1983); Cass R. Sunstein, Problems with Rules, 83 CALIF. L. REv. 953 (1995).

271. See discussion supra Part II.A.3.

272. One Congress-based proposal that seems to employ these criteria is Kirsten Engel's prescription for federal legislation mandating the internalization of costs modeled after the Low-Level Radioactive Waste Policy Act ("LLRWPA") discussed supra note 227. See Engel, supra note 140, at 1552. Her proposal would allow for state-level decision making under rules that require internalization of environmental costs. The LLRWPA gives states the option of providing for radioactive waste disposal individually or in regional compacts. Putting aside the pohitical feasibility of this approach, it seems relatively impervious to hostile interpretations by judges. However, we should also note that the LLRWPA has met its Pigovian aspirations only partially. Among the compact groups, several have experienced withdrawals by states selected to host the disposal site for the compact. See "Around the States" Regional Group Urges North Carolina to Fund Radioactive Waste Facility, 19 HAz. WASTE NEws 47 (Dec. 8, 1997); Tom Mecrsman, Waste Woes NSP, Others Face Stockpiling of Material as Dumps Shut Down, STAR Tribune-NewSPAPER of THE TwIN Cities July 4, 1994. Furthermore, studies of decision making withm the compacts support the idea that inefficient cost-shifting continues in this context. See Denmis Coates and Michael Munger, Not Equitable, Not Efficient: U.S. Policy on Low-Level Radioactive Waste Disposal, 13 J. PoL'y ANALYsIs \& MGMT. 526 (1994). In addition, noncompact states have resisted siting their own facilities. One large waste exporting state, New York, challenged the constitutionality of the statute after failing in its attempts to site a disposal facility. See New York v. United States, 505 U.S. 144 (1992). Thus, Engel's proposal merely moves the costshifting fight to another setting, as suggested by Ingberman. See Ingberman, supra note 54. However, it probably still represents an efficiency improvement over the status quo. For scholarly treatinents of siting probleins in connection with radioactive waste, see generally Frey \& Oberholzer-Gee, supra note 57; Kunreuther \& Easterling, supra note 153; Lober, supra note 57.

273. We refer here to the EPA's existing permitting programs for air and water pollution and pesticide regulation, among others. See also supra Part I.B (discussing federal regulatory apparatus).

274. Like most such mandates, this task is easier said than done, and it is beyond the scope of this article to develop the particnlars of the plan. However, two key elements of such a plan might be: 
existing RCRA permitting program ${ }^{275}$ could be expanded to fully incorporate municipal landfills.

Ideally, these changes could be endorsed by Congress, but that may not be necessary. The EPA already has the authority under RCRA to exercise some regulatory authority over municipal landfills under Subtitle D of that statute. ${ }^{276}$ Until recently, that authority remained largely unexercised, ${ }^{277}$ and most states already require permits for waste handling and disposal facilities under state law. There is no reason, apart from resource constraints, why the EPA could not oversee such a permit program for all waste facilities. The EPA has been moviug in that direction ${ }^{278}$ and has experieuce in the process of overseemg state permitting programs and ensuriug substantive adherence by state and local regulators to federal standards. ${ }^{279}$ Similarly, while there is no formal environmental cost-internalization requirement in current federal permitting standards, ${ }^{280}$ there is no reason why the EPA could not apply the Pigovian criterion to its oversight of all its delegated permitting programs, thereby encompassing a

(1) prohibiting the siting of facilities on the borders of the decision-making jurisdiction; (2) requiring each state or other political subdivision to provide disposal capacity sufficient to dispose of the externalities they generate, or to pay into a fund dedicated to compensating net importing states. On the latter issue, the development of efficient compensation schemes is difficult, not only because of the differential impacts of externalities within a jurisdiction, see Ingberman, supra note 54, but also because some economists argue that full compensation promotes market distortions of its own, see BAUMOL \& OATES, supra note 148 . Our main point here is simply to stress the relative greater political feasibility of this kind of incremental approach over approaches based on federal legislation.

275. See discussion of RCRA supra Part II.B.

276. Subtitle D comprises RCRA sections 4001-4010, 42 U.S.C. $\S \S 6941-6949$ a. The 1984 amendments to RCRA explicitly expanded the EPA's previously limited powers under Subtitle D. Specifically, RCRA section 4010(c) authorized expanded the EPA's authority to regulate solid waste landfills that receive hazardous household wastes, which includes most municipal waste landfills. See 42 U.S.C. $\S 6949$ a(c). Section 4005(c) required states to establish permit programs consistent with EPA standards for Subtitle D facilities. See 42 U.S.C. $\$ 6945$ (c).

277. Existing regulation of hazardous waste facilities occurs under RCRA Subtitle C, sections 3001-3023, 42 U.S.C. $\$ \$ 6921-6939$ (e). After RCRA's passage in 1976, the EPA left regulation of municipal landfills to states and local governments until the late 1980s. After years of litigation and intra-executive branch disputes, the EPA finally promulgated landfill standards for Subtitle D facilities in 1991. See 40 C.F.R. pt. 258 (1998).

278. The EPA's Subtitle D regulations include siting requirements, though most concern technical standards rather than prevention of socioeconomic impacts. See 40 C.F.R. $§ \S 258.10-258.19$.

279. See discussion supra Part I.B, especially note 50.

280. Certainly it can be said that one of the objectives of the pollution control requirements of the major permitting statutes is to internalize some costs. However, there is no cost-internalization requirement in connection with the flow of wastes in commerce. Section 104(c)(9) of Superfund requires the EPA to undertake an annual "capacity assurance planning" process according to which it asks states to certify that they have adequate disposal capacity for hazardous waste, as a condition for receipt of federal funds under Superfund. 42 U.S.C. § 9604(c)(9) (1995); see also EPA, Office of Solid Waste and Entergency Response, OSWER Directive No. 9010.02, Guidelines for Capacity Assurance Planning: Capacity Planning Pursuant to CERCLA 104(c)(9) (May 1993). However, this requircment does not effectively foree the internalization of external costs, since the EPA has granted exemptions from the certification requirement on numerous occasions, and does not preclude interstate transfers as a means of compliance. 
wider range of externality problems. Indeed, the EPA is already moving in that direction under its recent environmental justice initiatives. ${ }^{281} \mathrm{By}$ delegating the responsibility to police local cost-shifting to the EPA rather than the courts, Congress could place front-line decision-making authority in the hands of decision makers who are much more sympathetic to their Pigovian mission. Of course, our proposal does not eliminate the problem of vulnerability to judicial oversight. However, under our proposal, judges would be confined to reviewing agency interpretations under a relatively deferential Chevron standard, ${ }^{282}$ rather than directly applying a federal statutory mandate to state or local government action. Nor do we pretend that our proposal is immune to the political machinations of wasteexporting states whose interests might be hurt by a change $m$ the status quo. We think, however, that delegating the difficult decisions to the agency is a more politically palatable proposal than trying to address those decisions in legislation, and wiser than leaving them to state and local governments.

\section{B. Implication for Judicial Decision Making}

On the more general question of how judges decide, our analysis implies that a variety of variables play a role in determining federal judges' resolution of preemption disputes. Policy preferences play a role, regardless of judges' party affiliations. For Reagan appointees, both their Coasean preference for non-governmental solutions and their states' rights philosophy seem to play a role in their decisions. By contrast, we found no evidence that philosophies of federalisin or regulation guided either Democrats or other Republicans. In particular, we found no evidence that judges, or Democrats as a group, looked more favorably on Pigovian regulation that aimed to internalize environinental costs. Further, judges did look more favorably on state laws than on local laws, and were more likely to preempt the latter. Likewise, they tended to defer to federal agencies in Supremacy Clause cases. Finally, judges were more likely to preempt in Supremacy Clause cases than Commerce Clause cases, but the probability of preemption in Supremacy Clause cases varied imversely with the age of the underlying federal statute.

Of course, our results do not fully explain judicial decision making. We recognize that analyzing how and why judges make decisions is a messy business, and we have chosen to examine a particularly messy subset of those decisions. Nevertheless, we have undertaken this effort based

281. See Exec. Order No. 12,898, 59 Fed. Reg. 7,629 (1994), on Federal Actions to Address Environmental Justice in Minority Populations and Low-Income Populations, February 11, 1994; EPA, Office of Federal Activities, Final Guidance for Incorporating Environmental Justice Concerns in EPA's NEPA Compliance Analyses (Apr. 1998).

282. See Cross \& Tiller, supra note 183, at 2165 (suggesting that judges may use Chevron as a "non-deference doctrine"). 
on the assumption that this kind of empirical research is inherently valuable as a contribution to the body of evidence we bring to bear on the larger question of how judges make decisions. In resolving preemption disputes, the judges in our sample appear to have been influenced by both ideology and the characteristics of the cases. Some of the variables that appear to drive their decisions, such as deference to regulatory agencies, are explicit variables and are consistent with the traditional legal model of judicial decision making. Others, such as judges' policy preferences, are implicit variables of the kind to which legal realists and social scientists ascribe greater importance. Still others, such as judges' philosophies of regulation and their decreasing deference to the enacting Congress, fall somewhere near the boundary between implicit and explicit variables. Thus, on the more general issue of how judges decide, our results are mixed.

This should not be surprising. In his comparison of social science and legal approaches to the study of judicial decision making, Frank Cross describes the imteraction of the two approaches this way:

To steal a metaphor, consider the law to be ropes binding a judicial Houdim. The ropes may be tight or loose, possibly knotted with skill and redundancy. These ropes will strive to bind thousands of judges, each of whom possess [sic] different levels of escape skills. If we try to constrain judges with law, it is imperative to understand which brand of rope and which type of knot are most effective and inescapable. Consideration of the [social science approaches] and empirical research is the only approach that can effectively provide this understanding and materially affect practical results. ${ }^{283}$

Our findings are consistent with this metaphor and with the notion that no single model, or view of human nature, provides the key to understanding judges' decisions. In resolving difficult and complex preemption disputes, ideology and politics matter, but so do the law and the facts of the case.

\section{CONCLUSION}

Our analysis here highlights the irony of the status quo, in which modern preemption jurisprudence, administered by a largely Republican federal judiciary and motivated in part by conservative policy goals and a conservative (Coasean) philosophy of regulation, has facilitated a triumph of interest group politics. Specifically, it is a triumph for the political forces behind cost-shifting NIMBY movements. ${ }^{284}$ While NIMBYmotivated legislation has been preempted by the courts, NIMBY groups

283. Cross, supra note 183, at 326 (citations omitted). This description is reminiscent, once again, of Walter Murphy's advice to policy-oriented judges, more than thirty years ago. See Murphy, supra note 182.

284. See supra notes 261-62 and accompanying text. 
have nevertheless succeeded in restricting the availability of disposal capacity in exporting states. ${ }^{285}$ These same interests have also prevailed in Congress, where legislation to permit states to force the internalization of these costs has stalled. In fact, the only political setting where Pigovian advocates of cost-internalization have succeeded is at the state and local level. By failing to distinguish between Pigovian and cost-shifting regulations, federal judges who strike down these regulations serve those very same cost-shifting interests. Certainly it is the local political system that gives cost-shifting NIMBY groups part of their victory. However, the victory is made complete by the actions of (partly) ideologically-1notivated federal judges, soine of whose Coasean motives ignore these political realities in the name of promoting an efficient inarket solution.

285. Based on our observations of the responsiveness of local governments to this kind of pressure, the success of NIMBY movements in some states may be a fuuction of straightforward political pressure exerted on local governments, aimed at persuading them to dispose of their waste elsewhere. Of course, as these successes mount, transportation distances and disposal costs increase. Once again, the willingness of local citizeus to bear these costs will be a function of their ability to pay. 


\section{APPENDIX A: \\ TABle of CASES IN THE SAMPLe \\ Our Sample: Lower Federal Courts}

Atchison, Topeka \& Santa Fe R.R. v. Illinois Commerce Comm'n, 453 F. Supp. 920 (N.D. Ill. 1977).

Atlantic Coast Demolition \& Recycling, Inc. v. Board of Chosen Freeholders, 931 F. Supp. 341 (D.N.J. 1996).

Barker Bros. Waste v. Dyer County, 923 F. Supp. 1042 (W.D. Tenn. 1996).

Board of Elec. Light Comm'rs of Burlington v. McCarren, 563 F. Supp. 374 (D. Vt. 1982), aff'd, 725 F.2d 176 (2d Cir. 1983).

BFI Medical Waste Sys. v. Whatcom County, 983 F.2d 911 (9th Cir. 1992).

Brown v. Kerr-McGee Corp., 767 F.2d 1234 (7th Cir. 1985).

California v. Federal Energy Regulatory Comm'n, F.2d 743 (9th Cir. 1989).

Chambers Medical Technologies of S.C. v. Bryant, 52 F.3d 1252 (4th Cir. 1995).

Chappell v. SCA Servs., Inc., 540 F. Supp. 1087 (C.D. Ill. 1982).

Chemical Specialties Mfrs. Ass'n. v. Allenby, 744 F. Supp. 934 (N.D. Cal. 1990).

Chemical Waste Management, Inc. v. Templet, 967 F.2d 1058 (5th Cir. 1992).

City of Chesapeake v. Sutton Enters., Inc., 138 F.R.D. 468 (E.D. Va. 1990).

City of New York v. Ritter Transp. Corp., 515 F. Supp. 663 (S.D.N.Y. 1981).

City of New York v. U.S.D.O.T., 700 F. Supp. 1294 (S.D.N.Y. 1988).

Colorado Pub. Utils. Comm'n v. Harmon, 951 F.2d 1571 (10th Cir. 1991).

Colorado Pyrotechnic Ass'n v. Meyer, 740 F. Supp. 792 (D. Colo. 1990).

Condon v. Andino, Inc., 961 F. Supp. 323 (D. Me. 1997).

Connecticut Carting Co. v. Town of East Lyme, 946 F. Supp. 152 (D. Conn. 1995).

Consolidated Rail Corp. v. City of Bayonne, 724 F. Supp. 320 (D.N.J. 1989).

Coparr, Ltd. v. City of Boulder, 735 F. Supp. 363 (D. Colo. 1989).

D-CON Co. v. Allenby, 728 F. Supp. 605 (N.D. Cal. 1989).

Eastern Ky. Resources v. Fiscal Court of Magoffin Count., 127 F.3d 532 (6th Cir. 1997).

ENSCO, Inc. v. Dumas, 807 F.2d 743 (8th Cir. 1986). 
Environmental Encapsulating Corp. v. City of New York, 666 F. Supp. 535 (S.D.N.Y. 1987).

Environmental Tech. Council v. Sierra Club, 98 F.3d 774 (4th Cir. 1996).

Environmental Waste Reductions, Inc. v. Reheis, 887 F. Supp. 1534 (N.D. Ga. 1995).

Gary D. Peake Excavating, Inc. v. Town Bd. of Hancock, 93 F.3d 68 (2d Cir. 1996).

GSW, Inc. v. Long County, 999 F.2d 1508 (11th Cir. 1993).

Harvey \& Harvey, Inc. v. County of Chester, 68 F.3d 788 (3d Cir. 1995).

Houlton Citizens' Coalition v. Town of Houlton, 982 F. Supp. 40 (D. Me. 1997).

Illinois v. Kerr-McGee Chem. Corp., 677 F.2d 571 (7th Cir. 1982).

Jersey Cent. Power \& Light Co. v. Township of Lacey, 772 F.2d 1103 (3d Cir.), cert. denied, 475 U.S. 1013 (1985).

Kerr-McGee Chem. Corp. v. City of West Chicago, 732 F. Supp. 922 (N.D. Ill. 1990).

LaFarge Corp. v. Campbell, 813 F. Supp. 501 (W.D. Tex. 1993).

Maryland Pest Control Ass'n v. Montgomery County, 646 F. Supp. 109 (D. Md. 1986).

Maryland Pest Control Ass'n v. Prince George's County, 822 F.2d 55 (4th Cir. 1987).

Mega Renewables v. County of Shasta, 644 F. Supp. 491 (E.D. Cal. 1986). Missouri Pac. R.R. v. Railroad Comm'n of Tex., 671 F. Supp. 466 (W.D. Tex. 1987).

National Agric. Chem. Ass'n v. Rominger, 500 F. Supp. 465 (E.D. Cal. 1980).

National Solid Wastes Management Ass'n v. Williams, 966 F. Supp. 844 (D. Minn. 1997).

National Solid Wastes Management Ass'n v. Alabama Dep't of Envtl. Management, 910 F.2d 713 (11th Cir. 1990).

National Solid Wastes Management Ass'n v. Killian, 918 F.2d 671 (7th Cir. 1990).

National Solid Wastes Management Ass'n v. Alabama Dept. of Envtl. Management, 729 F. Supp. 792 (N.D. Ala. 1990).

National Tank Truck Carriers, Inc. v. City of New York, 677 F.2d 270 (2d Cir. 1982).

National Tank Truck Carriers, Inc. v. Burke, 535 F. Supp. 509 (D.R.I. 1982), aff'd, 698 F.2d 559 (1st Cir. 1983).

New Jersey State Chamber of Commerce v. Hughey, 774 F.2d 587 (3d Cir. 1985).

New York State Pesticide Coalition, Inc. v. Jorling, 874 F.2d 115 (2d Cir. 1989). 
New York State Pesticide Coalition, Inc. v. Jorling, 704 F. Supp. 26 (N.D.N.Y. 1989).

North Haven Planning \& Zoning Comm'n v. Upjohn Co., 753 F. Supp. 423 (D. Conn. 1990).

North Haven Planning \& Zoning Comm'n v. Upjohn Co., 921 F.2d 27 (2d Cir. 1990).

Northern States Power Co. v. Minnesota, 320 F. Supp. 172 (D. Minn. 1970).

Northern States Power Co. v. Minnesota, 447 F.2d 1143 (8th Cir. 1971).

Ogden Envtl. Servs., Inc. v. City of San Diego, 687 F. Supp. 1436 (S.D. Cal. 1988).

Ohio Mfrs. Ass'n v. City of Akron, 628 F. Supp. 623 (N.D. Ohio 1986).

Ohio Mfrs. Ass'n v. City of Akron, 801 F.2d 824 (6th Cir. 1986).

Pacific Gas \& Elec. Co. v. State Energy Resources Conservation \& Dev. Comm'n, 489 F. Supp. 699 (E.D. Cal. 1980).

Pacific Legal Found. v. State Energy Resources Conservation \& Dev. Comm'n, 659 F.2d 903 (9th Cir. 1981).

Pacific Legal Found. v. State Energy Resources Conservation \& Dev. Comm'n, 472 F. Supp. 191 (S.D. Cal. 1979).

Potomac Elec. Power Co. v. Sachs, 639 F. Supp. 859 (D. Md. 1986).

Professional Lawn Care Ass'n v. Village of Milford, 909 F.2d 929 (6th Cir. 1990).

Rivers Elec. Co. v. 4.6 Acres of Land in Town of Catskill, 731 F. Supp. 83 (N.D.N.Y. 1990).

Rollins Envtl. Servs., Inc. v. Parish of St. James, 775 F.2d 627 (5th Cir. 1985).

Samitation \& Recycling Indus., Inc. v. City of New York, 928 F. Supp. 407 (S.D.N.Y. 1996).

SDDS, Inc. v. South Dakota, 47 F.3d 263 (8th Cir. 1995).

SED, Inc. v. City of Dayton, 519 F. Supp. 979 (S.D. Ohio 1981).

Southcentral Penn. Waste Haulers Ass'n v. Bedford-Fulton-Huntingdon Solid Waste Auth., 877 F. Supp. 935 (M.D. Pa. 1994).

Southern Pac. Transp. Co. v. Public Serv. Comm'n of Nev., 909 F.2d 352 (9th Cir. 1990).

SSC Corp. v. Town of Smithtown, 66 F.3d 502 (2d Cir. 1995).

Town of Springfield v. McCarren, 549 F. Supp. 1134 (D. Vt. 1982).

Town of Springfield v. Vermont Envtl. Bd., 521 F. Supp. 243 (D. Vt. 1981).

Twitty v. North Carolina, 527 F. Supp. 778 (E.D.N.C. 1981); conpanion to Warren County v. North Carolina, 528 F. Supp. 276 (E.D.N.C. 1981), both aff' $d$ by 696 F.2d 992 (4th Cir. 1981).

United States v. City of New York, 463 F. Supp. 604 (S.D.N.Y. 1978).

Union Pac. R.R. v. City of Las Vegas, 747 F. Supp. 1402 (D. Nev. 1989). 
United Steelworkers v. Auchter, 763 F.2d 728 (3d Cir. 1985).

USA Recycling, Inc. v. Town of Babylon, 66 F.3d 1272 (2d Cir. 1995).

Waste Management of Mich. v. Ingham County, 941 F. Supp. 656 (W.D. Mich. 1996).

\section{Supreme Court Cases}

Wisconsin Pub. Intervenor v. Mortier, 501 U.S. 597 (1991).

Gade v. National Solid Wastes Management Ass'n, 505 U.S. 88 (1992).

California v. Federal Energy Regulatory Comm'n, 495 U.S. 490 (1990).

City of Philadelphia v. New Jersey, 437 U.S. 617 (1978).

Chemical Waste Management, Inc. v. Hunt, 504 U.S. 334 (1992).

Fort Gratiot Sanitary Landfill, Inc. v. Michigan Dep't of Natural Resources, 504 U.S. 353 (1992).

Oregon Waste Systems, Inc. v. Dep't of Envtl. Quality of Or., 511 U.S. 93 (1994).

C\&A Carbone, Inc. v. Town of Clarkstown, 511 U.S. 383 (1994). 


\section{APPENDIX B: \\ Notes on Statistics and Data Coding}

\section{Explanation of Methods}

Our statistical analysis of these preemption decisions uses a relatively simple and straightforward statistical tool that others have employed to analyze judicial decisions: "logit" analysis. Logit analysis is a form of multivariate regression, one of a family of so-called "maximum likelihood" regression methods. Like other regression models, logit analyses simultaneously measure the individual relationships between several independent variables and a single dependent variable. Maximum likelihood methods, mcluding logit, are particularly useful where the dependent variable is nominal or categorical, that is, not contmuous. For example, a judicial decision in a preemption dispute has only two possible outcomes, ${ }^{286}$ rather than a wide range of outcomes. ${ }^{287}$ Logit is now widely used to analyze judicial decisions, particularly among social scientists. ${ }^{288}$ In logit models, the dependent variable is calculated as the probability that the judge will reach a particular decision. ${ }^{289}$ By coding the judges' decisions and the independent variables (as described below) into categories, we can use statistical software to estimate a logit model of the simultaneous effect of each independent variable on the probability that the judge will reach a particular decision. We can then estimate the effect of each variable on the probability that judges will preempt state or local regulations.

\section{Sample}

As discussed im the main text, we elected to limit our sample of cases in several important ways, although the sample comprises the lion's share of federal court preemption cases in the last three decades. First, because

286. This holds true for all the cases in our sample except those few that raised the issue of "partial preemption." See our discussion of the coding of these cases infra p. 1206.

287. For a thorough discussion of maximum likelihood methods, including logit, see WILLIAM H. Greene, Econometric Analysis (1990), especially 333-362; Gary King, Unifying Political MeThodology: THe Likelihood TheORY of Statistical INFEREnCE (1989), and MAddala, supra note 179 , especially $13-58$;

288. For a good explanation of the use of logit to analyze judicial decisions, see Segal \& Spaeth, supra note 185 . See also the summary of the use of maximum likelihood estimation in traditional law reviews, supra note 238.

289. The mathematical calculations behind the logit model are complicated, but are typically expressed as follows: where (1) $\mathrm{Y}$ signifies the observed value of the dependent variable, (2) $\mathrm{X}$ signifies the observed value of the independent variables, (3) $\beta$ signifies the coefficients for the independent variables, (4) the dependent variable is a binary choice coded either " 1 " or " 0 ", and (5) $e$ is the number $e$ ):

$$
\operatorname{Prob}(Y=1)=e(-\beta X) /(1+e(-\beta X))
$$

Once again, we relied on statistical software to make these calculations for us. 
our ultimate aim is to explain judicial decision making, we limited the sample to those cases involving open legal issues. ${ }^{290}$ Thus, we eliminated cases where binding higher precedent, which could not be distinguished, determined the outcome. ${ }^{291}$ For this same reason, we included only those Supremacy Clause preemption cases arising under federal statutes that had produced a body of preemption case law, measured as more than two cases, on the assumption that the number of cases arising under the statute was one indicator of the existence of an open legal issue as to preemption. ${ }^{292}$ By limiting our sample to open legal issues-or in other words, hard cases-we sought to ensure that our sample would have the variation for which we hoped to provide an explanation. ${ }^{293}$

Second, we did not include Supreme Court decisions in our analytical sample. We concluded that Supreme Court decisions, while an important contextual force in lower court decisions, were sufficiently different in nature that we could not compare thein directly with lower federal court decisions. Some of the variables that explaim the former appear to be fundamentally different from those that explam the latter. Although we provided some description of Supreme Court preemption decisions, we opted not to analyze them separately, partly for this same reason and partly because there were too few decisions to allow for a statistical analysis.

Third, we limited ourselves to published decisions. Not all federal district court decisions are published, and it is clear from a perusal of the sample (and the prevalence of circuit court opinions) that some federal district court preeinption cases have remained unpublished. ${ }^{294}$

290. See our discussion of the relationship between this decision and the amount of explainable variance in the decisions.

291. This is, of course, not always a straightforward determination to make. Fortunately, it only arose in a few cases. Where it did, we erred on the side of including the decision in our sample. The primary context in which this issue arose was in the Federal Power Act preenption cases. As described, supra, at Part II.B, the Supreme Court's 1940s-era First Iowa decision seemed to compel preemption; however, in that imstance, a more recent Supreme Court decision (involving similar statutory language in another statute) seemed to call the earlier precedent into question. Because that argument was sufficiently strong to persuade at least one federal court to contradict the earlier precedent, we elected to include that body of cases in our sample. However, when we ran our logit regression excluding the Federal Power Act cases, our results did not change. All the same coefficients were statistically significant with the same sigus. We also faced this issue with respect to Commerce Clause cases that followed closely on the heels of Supreme Court cases, and took a similar approach. Our justification for erring on the side of mclusion is that while courts may explicitly rely on "controlling higher authority" in reaching a decision, that position was belied by splits among courts on identical legal issues. See Cross \& Tiller, supra note 183 (finding that lower courts iguore Supreme Court doctrine under certain circumstances). For a discussion of how this may effect our sample, see infra note 248.

292. For example, we did not include Supremacy Clause preemption cases arising under the Clean Air Act, Clean Water Act, or Superfund, because none produced a large enough body of federal court preemption decisions for us to analyze.

293. See our discussion of sample truncation in the text, infra p. 1202.

294. This issue may be related to the problem of the overrepresentation in our sample of cases preempting state or local laws. We can infer that if politicians are more likely to pursue losing cases than industry/developers, politicians may also be inore likely to appeal these cases as well. 
Fourth, we did not include state court decisions in our sample although some preemption cases are decided in state courts. While we did not make an exact count of those cases, we estimate that they represent about one third of the universe of preemption cases that otherwise satisfy our other sample criteria. We elected to exclude those cases because of the significant difficulties associated with analyzing the motives and behavior of federal and state judges together. The latter are often elected for finite terms of office while the former are appointed for life (barring impeachable behavior). This difference means that we can expect state judges to be far more susceptible than federal judges to political forces, irrespective of their greater proximity to local problems and issues. We were therefore hesitant to include both sets of judges im a single analysis. ${ }^{295}$

\section{Sample Truncation and Selection on the Dependent Variable}

We discuss in Part III.A.1 of the main text the potential for bias toward preemption outcomes in the sample, because of politicians pursuing litigation despite a low probability of success. Another related data censoring problem, which we did not discuss in the text, applies to any analysis of judicial decisions. A commentator at a seminar presentation of an earlier version of this Article questioned whether litigation outcomes represent situations containing any "non-stochastic" (that is, systematic, explainable, or non-random variation.) This view holds that the settlement process filters out the great majority of the universe of disputes, leaving only those close cases that turn on random factors. ${ }^{296}$ Stated differently, judges may have predictable responses that separate liberals from conservatives in the cases that are settled, but the difficult features of the litigated cases mask those predispositions.

We think this argument is incorrect. To the contrary, there should be more of the variation we seek to explain in litigated cases than in settled cases. Cases are often settled because one or both of the parties perceive that the outcome is dictated by statute or precedent or some other factor that precludes the exercise of discretion by the judge. It is that discretionary choice in which we are interested. The opportunity for non-stochastic variation to determine outcomes is maximized, not minimized, in these close cases. ${ }^{297}$ Indeed, we undertake this analysis on the assumption that

295. In a prior analysis of Supremacy Clause decisions that included state court cases, the type of judge involved (federal vs. state) appeared not to exert any influence on the probability of preemption. See Spence, supra note 207, at 18.

296. See Personal Communication with Professor Mark Fey, Princeton University (Feb. 1997).

297. Aschenfelter et al., put it this way:

In close cases, something must make a difference. It could be random fluctuation, what the judge ate for breakfast, the judge's background, or other less obvious factors. It is not self-evidently disturbing when the judge's worldview (as revealed by party affiliation or other variables) dominates over some competing sources of decision. 
preemption jurisprudence is sometimes internally imconsistent because it presents just that sort of opportumity. Maximizing the opportunity for explainable judicial discretion to play a role is also the reason why we limited our sample to cases involving open legal issues. ${ }^{298}$

\section{Coding the Dependent Variable}

For the bivariate and logit analyses, each federal judge's decision was coded as a separate observation. The decision variable was coded " 1 " for a decision favoring preemption of state or local law, "0" otherwise. For a few decisions, the court decided that the state or local regulation in question was preenipted, but only in part. These cases required a subjective assessment of whether most of the local regulation, or whether its most important parts, were preempted. Most such "partial preeinption" decisions arose under OSHAct, and often the court overturned the portions of local law that regulated workplace hazards and let stand the portions that did not. We coded those decisions based upon how the court decided the local regulation's applicability to workplace hazards, because that subject more closely reseinbled the other police power issues in our sample.

\section{Coding the Independent Variables}

Infornation about judges' party affiliations and the appointing president was found in the Almanac of the Federal Judiciary ${ }^{299}$ and Biographical Dictionary of the Federal Judiciary. ${ }^{300}$ In those few instances in which no party affiliation was listed, the party of the appointing president was used. PARTY was a dummy variable, coded " 1 " for Deinocrats and " 0 " for Republicans.

The Pigou variable was coded as described in the text and accompanying notes. We attempted to identify the "Pigovian" position in the cases. When the Pigovian position was to preempt, we coded the variable "1." When it was not to preempt, we coded it "0." For cases involving a local attempt to shift a firm or political subdivision's environmental costs to others, the Pigovian position is to preempt, because the local law is essentially an attempt to externalize these costs. On the other hand, for local laws that

Orley Ashenfelter et al., Politics and the Judiciary: The Influence of Judicial Background on Case Outcomes, 24 J. LEGAL STUD. 257, 263 (1995).

298. It is, of course, possible that our efforts to exclude cases subject to binding precedent were not perfectly successful. See discussion supra note 291 . To the extent that the sample includes cases the outcome of which was determined by such authority, those cases will indeed minimize the explainable variation in these decisions. These cases could also exacerbate the bias toward preemption outcomes in the sample if that binding precedent mandated a preemption outcome.

299. Almanac of the Federal Judiciary (Bamabas D. Johnson et al. eds., Aspen Law \& Business 1999).

300. Biographical Dictionary of the Federal Judiciary (Harold Chase et al. eds., 1976). 
attempt to force firms or other subdivisions to internalize their own costs, the Pigovian position is not to preempt. ${ }^{301}$

Likewise, the COASE variable was coded as described in the text and accompanying notes, and was coded so as to identify the "Coasean" position in each dispute. Thus, where the Coasean position called for preemption, the Coase variable was coded "1"; where it called for upholding the state or local regulation, it was coded " 0 ." In inost instances, the Coasean position was synonyinous with an anti-regulatory poimt of view, and generally (although not perfectly) ${ }^{302}$ coinpleinentary to the Pigou variable. ${ }^{303}$

The interaction variables were coded so as to isolate the effect of philosophy of regulation on particular judges. In each case, the aim was for the philosophy variable to vary, by taking one of two polar positions, only for decisions for which the judge had the desired characteristic. In all other cases the variable took a constant, middle value. Thus, for example, the Pigovian Position/Democrats OnLY variable was coded so that for decisions by Democrats, the variable took a value of "1" if the Pigovian position were to preempt and a value of " 0 " if the Pigovian position were to uphold the local law. In all other cases, the variable took a value of "0.5." The same approach was used for the other two interaction variables (Coasean Position/Republicans Only and Coasean Position/Reagan APPOINTEES ONLY).

The CASE TYPE variable distinguishes Supreinacy Clause cases from Commerce Clause cases and was coded " 1 " for the former and " 0 " for the latter.

301. This is sometimes a fine distinction. Generally, where an import ban was part of a comprehensive state or local waste management law that sought to require communities to provide for disposal of their own waste, the Pigovian position was not to preempt. Consistent with this view, most flow control cases involved ordinances that required local waste to be taken to a local facility; hence, the Pigovian position in these cases was not to preempt. Where an import ban was not accompanied by requirements that local waste be disposed of locally, or where the ordinance in question imposed a broader dumping ban, the apparent intent was to externalize the commuuities environmental costs. In such cases the Pigovian position was to preempt.

302. The exception to this rule were cases involving local right-to-know laws, in which both the Coasean and Pigovian positions were not to preempt, since one purpose of right-to-know laws is to facilitate both Coasean solutions and the internalization of exterual costs.

303. Coding the Coase variable also required us to make another, somewhat arbitrary assumption. Because the Coasean view advocates private negotiated solutions to externality problems, we had to decide who the appropriate bargaining units are. In the usual case, we think of individual economic actors in the market as the bargaining urits, and this is what most of the Coasean justifications of modern preemption doctrine seem to imply. See supra note 164. However, Coasean bargaining could take place between governmental umits. Indeed, this is what Butler \& Macey, supra note 54, propose. If we were to assume bargaining between local governments, that would change our coding scheme, and would raise other issues about rules according to which such bargaiming would take place. Since the case law clearly seems aimed at protecting mdividual economic rights, not local government rights, we have assumed the desirability of Coasean bargaining between individuals in making our coding decisions. 
The ALARM Issue variable was coded as described in the text, " 1 " if the case involved an alarm issue, " 0 " otherwise.

The AGENCY Position variable was coded " 1 " if the agency adopted a position favoring preemption in the case, " 0 " otherwise. Agency positions were taken from one of the following sources: (1) the agency's direct participation in the case, either as a party or as amicus; (2) agency regulations (as with all cases arising under OSHAct and TSCA); (3) other agency pronounceinents contained in formal agency actions (such as orders, as with cases arising under the FPA).

The TIME variable was the year of the decision. The TIME Distance variable was simply the number of years between passage of the underlying federal statute and the decision, for Supreinacy Clause cases only. In all other cases it was coded " 0. "

The STATE OR LOCAL REgULATION variable was coded " 1 " for cases involving challenges to state laws or regulations, " 0 " otherwise.

\section{Model Estimates}

Using the logit methods described above, our model produced the coefficient estimates listed in Table 12, page 1206. As described in the text, we were reluctant to ascribe too inuch importance to the magmitude of the coefficient estimates, particularly because it is difficult to interpret the size of the effects produced by the indicator variables. Hence, we inerely report them here, along with measures of the model's overall fit to the data. 
TABle I2: Relationships Between Explanatory Variables and Decision OUTCOMES

\begin{tabular}{|c|c|c|c|c|c|}
\hline \multicolumn{2}{|c|}{ Internal/Ideology Variables } & \multicolumn{2}{|c|}{$\begin{array}{l}\text { Ideological Interaction } \\
\text { Variables (Indicators) }\end{array}$} & \multicolumn{2}{|c|}{ External Variables } \\
\hline VAR. & COEFF. ${ }^{304}$ & VAR. & CoEfF. & VAR. & CoEfF. \\
\hline INTERCEPT & -251 & $\begin{array}{l}\text { PIGOVIAN } \\
\text { Position / } \\
\text { DEMOCRATS } \\
\text { ONLY }\end{array}$ & -0.5 & $\begin{array}{l}\text { CASE TYPE } \\
\text { (CONTROL) }\end{array}$ & $\begin{array}{c}373 \\
(p<1)\end{array}$ \\
\hline $\begin{array}{l}\text { PARTY } \\
\text { (DEMOCRAT) }\end{array}$ & $\begin{array}{c}-2.5 \\
(p<.05)\end{array}$ & $\begin{array}{l}\text { COASEAN } \\
\text { POSITION / } \\
\text { REPUBLICANS } \\
\text { ONLY }\end{array}$ & $\begin{array}{c}-1.8 \\
(p<.05)\end{array}$ & $\begin{array}{l}\text { STATE OR } \\
\text { LOCAL } \\
\text { REGULATION }\end{array}$ & $\begin{array}{c}-0.4 \\
(p<05)\end{array}$ \\
\hline $\begin{array}{l}\text { REAGAN } \\
\text { APPOINTEE }\end{array}$ & $\begin{array}{c}-2.2 \\
(p<05)\end{array}$ & $\begin{array}{l}\text { COASEAN } \\
\text { POSITION / } \\
\text { REAGAN } \\
\text { APPOINTEES } \\
\text { ONLY }\end{array}$ & $\begin{array}{c}1.6 \\
(p<05)\end{array}$ & $\begin{array}{l}\text { FEDERAL } \\
\text { AGENCY } \\
\text { PosITION }\end{array}$ & $\begin{array}{c}1.2 \\
(p<05)\end{array}$ \\
\hline $\begin{array}{l}\text { COASEAN } \\
\text { POSITION } \\
\text { (INDICATOR) }\end{array}$ & $\begin{array}{c}1.2 \\
(p<.05)\end{array}$ & & & $\begin{array}{l}\text { ALARM } \\
\text { ISSUE } \\
\text { INVOLVED? }\end{array}$ & -0.3 \\
\hline $\begin{array}{l}\text { PIGOVIAN } \\
\text { PosItION } \\
\text { (INDICATOR) }\end{array}$ & $\begin{array}{c}-0.7 \\
(p<.05)\end{array}$ & & & $\begin{array}{l}\text { TIME } \\
\text { TIME } \\
\text { DISTANCE }\end{array}$ & $\begin{array}{c}0.1 \\
\\
-0.2 \\
(p<1)\end{array}$ \\
\hline
\end{tabular}

304. Statistically significant results are italicized. 